\title{
Chapter Two: Bodies of Evidence
}

\section{PART 1: AN ORCHESTRATED LITANY OF LIES ${ }^{1}$}

A crowd scarcely distinguishes between the subjective and the objective. It accepts as real the images evoked in the mind, though they most often have only a very distant relation with the observed fact.

The whole Dreyfus Affair can, from one perspective, be seen as a long debate about the nature of evidence and thus about real and false documents, shredded papers glued together, and forgeries, interfered-with letters, secret and nonexistent pieces of paper, handwriting experts, and discrediting of testimony-about what does and what does not constitute the truth, the whole truth and nothing but the truth. From another perspective, sometimes that of hindsight and sometimes that of denial and wilful self-blindness and-deafness, it is about anti-Semitism, about the way the prosecutors in the drawn-out controversy do all they can to prove Dreyfus the Jew guilty because Jews must by virtue of their being Jews be traitors and liars. Most of the Dreyfusards do all they can to avoid dealing with this issue of anti-Semitism and to claim instead that the affair is about truth and justice, about the honour of individuals and

Justice Peter Mahon, Royal Commission of Inquiryinto the Erebus Disaster (27 April 1981), examining the cover-ups used to protect Air New Zealand from full responsibility for the crash of a chartered tourist flight over Antarctica. As in the Dreyfus Affair, the arrogance of power came fully into play in a conspiracy of silence, duplicity, and pressure from both the New Zealand government and its national airlines. Amidst the claims and counterclaims, there were denials, calls for further investigations, and resignations. For instance, "Air New Zealand asked for their judicial review of the Inquiry's allegations and findings to be heard in the Court of Appeal rather than the High Court. Their request was initially rejected, but later accepted because of 'the magnitude of the disaster,' 'the public importance of the issues' and 'the conduct of an inquiry held by a high court judge." Similarly, "Justice Mahon resigned from the bench of the High Court in January 1982." See, for instance, "Court action following Erebus disaster inquiry: Cabinet accepts Judge Mahon's resignation," online at http://NZHistory.net.nz/media/photo/ongoing-debate-about-erebusdisaster (seen 21 October 2010).

Le Bon, The Crowd, 41. 
the honour of the republic, the army, and the church. ${ }^{3}$ Some people on both sides, perhaps exhausted by those arguments, when it came time to fight for Dreyfus's rehabilitation, decided the honour of the army and the security of the republic were more important than the honour or welfare of a single man, so that it did not matter at all whether he were guilty or innocent-due to expediency and reasons of state.

The more we examine the body of evidence adduced during the two courts martial against Alfred Dreyfus, the more it appears that Peter Mahon's expression is an apt way to describe the whole Dreyfus Affair: an orchestrated litany of lies. Almost all the books dealing with the affair are concerned with political and judicial questions, about the truth content of various documents and testimonies. ${ }^{4}$ This book is also about evidence in a larger sense; about the nature of documents, testimony, and thus truth that can be articulated in a court of law and in the public media - that is, about the ways in which lawyers and judges, newspaper reporters and editors, construct illusions of truth in their arguments and, consequently, about the ways in which such spoken and written speeches are heard and understood by juries, other agents of the judicial and political systems, the readers of newspapers, and the spectators at various modes of conveying secondary reproductions of the courtroom drama on the stage, in films, printed on postcards, modelled into wax museums - in brief: a whole industry of propaganda developing at the time of the Dreyfus Affair.

Still another kind of evidence comes into focus in this book about Alfred Dreyfus, the man and the milieu, and the mentality and the midrash, for this study I have undertaken is not an attempt at biography or social history. It is primarily an examination of the surviving texts, especially those written at various times and under various conditions in his life during and after the affair by Alfred Dreyfus himself and by his wife. The examination uses the techniques of the history of mentalities and psychohistory but is not strictly or exclusively an exercise in either of those disciplines. I also examine Dreyfus's letters, journals, carnets, and cahiers

3 Romain Rolland: “Christophe asked Olivier: 'You have been lifted to the stars and hurled down to the depths of hell by your Dreyfus affair. Where is the poet in whose soul the height and depth of it were felt?"' (Jean Christophe, vol. II, 325).

4 Edmond Jabès wrote in Du Désert au livre (Paris: Belfond, 1980): "Le Juif ne se pose pas seulement des questions; il est lui-même devenu question" (The Jew not only asks questions; he himself becomes a question) cited by Ouaknin, Le livre brûlé, 262, n. 9. 
as though they were texts of midrash and the midrashing of experience in themselves, and at the same time, I conduct the examination as though I were myself writing a midrash on Alfred Dreyfus.

In this last kind of study, there are three constitutive bodies of evidence that were composed by Captain Dreyfus during his years of imprisonment, exile, and forced isolation and silence and the twelve years that followed, during which he fought for his complete exoneration and the restoration of his good name. First, there are the personal letters, written between Alfred and Lucie Dreyfus for the most part, although there are occasional epistles between Alfred and his brother and the close allies he knew about before he was packed off into the oblivion of the French prison islands off the coast of northeastern South America. These letters shade off into printed collections, including edited versions of the original epistles, introductory remarks by the intimate parties, their relatives, their political supporters, and eventually academic students of the affair. Second, Alfred also kept workbooks or cahiers while he was in prison and journalistic notebooks or carnets during the second phase of his struggle when he returned to France.

As we shall see, he seems never to have intended the cahiers for anyone to see but himself, and actually destroyed at least half of them himself; they are remarkable therefore for two reasons: (a) because they are physical imprints of his experiences in isolation over an extended period of time; and ( $b$ ) because they were read and reported on by his prison guards and political officials back in Paris. Third, the journals are evidence of a somewhat different kind, although they form an edited version of his feelings and opinions during the period of time they were written and, as reflected in later years, they can be seen as much more than a running record of his daily affairs, his immediate thoughts concerning the fight to rehabilitate his name after the second court-martial in Rennes, and the pardon he felt forced to accept because of his frail physical and psychological condition, along with copies of letters and conversations he and others had in that long period from 1899 to 1906.

\section{Twelve Years of Lost Time}

Cette animosité se dissimulait communément et cependant le juif intelligent la perçoit. Il sent une résistance devant lui, 
il a l'impression d'un mur que des adversaires ont dressé entre lui et ceux au milieu desquels il vit.

- Bernard Lazare ${ }^{5}$

In most of their lives before the affair and especially the five years of their marriage prior to that fateful Saturday morning in 1894, Lucie and Alfred Dreyfus pretended to themselves that they were assimilated, part of French society, and that anti-Semitism was something that did not impinge on their lives. ${ }^{6}$ They refused to see the wall that had been set up between them and the rest of society, and when it was too late, they lost five years of their lives trying to find a way to dismantle that wall to free Alfred, and another seven to get him rehabilitated. Or so it would seem. ${ }^{7}$ This book makes a somewhat different point. I argue that for the horrors of the incarceration, the shame of imprisonment, and the tortures, physical and psychological, that the couple endured, the wall never really came down. Yet, because of the false accusations, the judicial errors, the forgeries, and the purged testimonies, Alfred and Lucie in their letters to one another and in the journals that Alfred kept created something very important, and discovered and invented new aspects in themselves and their relationship. To a certain very limited degree, Lucie was able to start drawing out the reticent and shy young man who courted and then married her. As Michael Burns puts it, commenting on the first letters

5 "This animosity usually dissimulates itself and yet the intelligent Jew sees it. He senses a resistance before him, he has the impression of a wall that his adversaries have constructed between himself and those others in among whom he lives": Bernard Lazare, "Le nouveau ghetto," La Justice (17 November 1894), cited in Bloch-Dano, Madame Proust, 302.

6 As Eveylne Bloch-Dano says of Jeanne Proust, Marcel's mother, "Comme des parents, elle est et restera une israélit, parfaitement intégrée à la société qui, autrefois accueillit ses ancêtres" (Like her relatives she was and would remain an Israelite, perfectly integrated into the society which formerly had welcomes her ancestors), Madame Proust, 21. Jeanne never converted, and her husband, Dr. Adrien Proust, never demanded that she do so; the family Marcel grew up in what was nominally a Christian household, but he freely visited with his Jewish relatives and felt, particularly at the time of the Dreyfus Affair, a loyalty to the Jews (29). Like the Dreyfus family, the Weils had come from Alsace (32), but they had not only enriched themselves in Paris; as we see in Jeanne's life, they intermarried with the Christian political, professional, and intellectual elite (38), whereas Alfred and Lucie's background was more restricted to the comfortable manufacturing and professional Jewish community. Thanks to the affair, however, their two children, Pierre and Jeanne, moved into the circle of intellectuals, such as the Reinach brothers.

7 That even supposedly tolerant Frenchmen and women, supposedly supporters of the wrongly accused Dreyfus, could harbor anti-Semitic prejudices may be seen in regard, for instance, to Emile Zola's wife, who noted the predominance of Jews on the stock market and considered many professions as specifically Jewish (Bloch-Dano, Madame Proust, 60). Later in this book, I shall discuss different kinds and degrees of Judeophobia and their implications. 
Alfred wrote to his intended while on manoeuvres:

Lucie discovered her fiancé's mercurial moods, the abrupt shifts from lighthearted descriptions of standing watch on a frigid night with a horse whose whole purpose in life was "to return to the stable" to his obsession with work and a relentless perfectionism that made him appear selfish and insensitive. He admitted that it had always been difficult for him to share his private feelings, to "open up," and he agreed that Lucie had a right to know more about the man to whom she was "entrusting" her life. ${ }^{8}$

Foreshadowing the way they would learn to communicate in a kind of group therapeutical dialogue, Alfred responds to her questions and challenges, perhaps most of them implied by his own imagining of how she must see his flaws rather than actually present in her own cautious address to the older man she was soon to marry.

He would try to express himself and to break his "disastrous habit: of taking everything seriously. But he pleaded with her not to interpret his reserved manner as insensitivity: "Surface insensitivity . . . I grant you," he wrote, using the vous, the formal address of a proper young suitor. "The real thing, no!" "I hope you'll come to realize," he added, "that however retiring I may be, I love you deeply."

Then, a year later, in the spring of 1890 , using one of those most prescient figures of speech that we will have to come back to deal with in the next volume, where we shall discuss Dreyfus's place in the artistic culture of the late nineteenth century, he tells Lucie,

For two instruments to produce a harmonious sound to-

8 Burns, Dreyfus: A Family Affair, 83. It is a further frustration to realize that there are so many letters written between Lucie and Alfred from before his imprisonment that have yet to be transcribed, edited, and published.

9 Burns, Dreyfus: A Family Affair, 83. 
gether, they must be in tune, as in music. In physics, it's called "synchronic vibrations." 10

There is no complete edition of all the letters written between Alfred and Lucie Dreyfus nor between Alfred and other members of his family and allies before or during his period of imprisonment, and none between Lucie and her family, friends, and government officials. Each book containing letters has a different, overlapping selection, and each is set in a different context with its own polemical or scholarly purpose. Nevertheless, given these constraints, I believe it is possible to analyze these letters and to draw a number of-one need not say preliminary but at least new kinds of-conclusions about the husband and the wife and their relationship to each other during the five years of separation between 1894 and 1899.

In 1901, already back in France and now pardoned, Dreyfus published Cinq années de ma vie, ${ }^{11}$ a book dedicated to his children, in which he sets forth his ordeal as an unjustifiably accused and condemned Frenchman in order to establish his ethical (moral) credentials, seeks to evoke sympathy from any in the not-yet-convinced general public ready to support his cause, and appeals to his allies for their help in gaining full rehabilitation of his honour and rank. The letters are meshed into a text that includes an apologetic account of his life and the polemical argument for his innocence. At no point does he plead for mercy or pity, call attention to himself as an object of anti-Semitic prejudice, or cast aspersions on the army, the government, or the nation. What he does say is that he suffers physically and morally and has to make a special effort to avoid sliding into the depths of despair. He draws pictures of the island prison where he was sent into exile ${ }^{12}$ and the hut, with its palisade blocking the sea, which kept him in solitary confinement and under the constant surveillance of guards who were under strict orders not to communicate with him. ${ }^{13}$ This regimen of silence and isolation, along with poor food, sanitary conditions, and

10 Burns, Dreyfus: A Family Affair, 83.

11 Alfred Dreyfus, Cinq années de ma vie (1894-1899), with an introductory essay by Pierre VidalNaquet and an afterward by Jean-Louis Lévy (Paris: Editions la Découverte, 1994; this edition first published by Editions Francois Maspero, 1982).

12 Cinq années de ma vie, 100.

13 Cinq années de ma vie, 102. 
insalubrious weather, increasingly wore him down.

He also inserts a journal that he kept for the first two years (1895 and 1896) to be sent eventually to his wife Lucie. Thus we know that on Sunday, 14 April, 1895, he wrote: “Je commence aujourd'hui le journal de ma triste et épouvantable vie" (Today I begin the journal of my sad and horrible life). ${ }^{14}$ What he is concerned with is the tediousness and discomfort of his life in exile, his silence which keeps him at best in conversation with himself, and the failure of letters to arrive, the paucity of paper with which to write, and the lack of reading material.

Several little points come up, however, that seem to test his Jewish character and tastes. One, which Dreyfus makes no especial note of, is the fact that he was called in to confront the charge of treason on 13 October, 1894, barely two weeks after beginning his service in the Statistics Department (i.e., Intelligence Bureau) of the army in Paris; that day was a Saturday, the Jewish Sabbath, or shabat. ${ }^{15}$ Although he as an assimilated Jew may have normally worked on this holy day, his accusers would have been aware of the irony-and the deliberate insult they were paying to this unwanted Semite in their midst. Dreyfus, however, does not react.

Day by day, week by week, Dreyfus notes in his prison journal and in his letters to Lucie sketchy, vague details of his feelings, very little of what is actually happening - there is no narrative in his life to be recorded-and, at most, only tantalizing hints of what he thinks about. ${ }^{16}$ At times, both Alfred and Lucie refer to the ordeal as martyrdom or a calvary, using these very Christian reference words in a general, secularized form. ${ }^{17}$ "Days are lugubrious. Everything is forbidden to me, the perpetual tête-à-tête with my own thoughts" (8 March, 1896). ${ }^{18} \mathrm{He}$ finds

14 Cinq années de ma vie, 103.

15 Cinq années de ma vie, page 51 at the start of his chapter 2.

16 It will be evident soon enough how the writing of such hints (remez, as the rabbis call them) are important, especially when they appear on the page inadvertently.

17 Or at least in a neutral sense. Ambiguity occasionally creeps in, though, as when Lucie reports that she and the children have gone to her family for dinner at Pâues, a term normally used for the Christian celebration of Easter, sometimes for Passover, but then usually presented as "the Jewish Pâcque" in the singular. Because it is more than likely that the family gathered for a Passover seder, not a vague and indeterminate Easter-holiday meal, those historians who translate the expression as "Passover meal" are correct up to a point, the point being that Lucie, like Alfred, aware of censorship, sought to avoid any direct indications of their Jewishness. Much later, Lucie makes reference to the eight days of Hanukkah, with the children happy as kings and excited with their presents (Ecris-moi souvent, écris moi longuement, 393).

18 “Journées lugubres. Tout m'est interdit, le tête-à-tête perpétuel avec mes pensées" Dreyfus, Cinq années, 
himself crystallized in his own pains ${ }^{19}$ He suffers from nerves all night. ${ }^{20}$ "A horrible night of fever and delirium." ${ }^{11}$ These are not imaginary pains and anxieties: "I was put into irons last night! Why? I don't know why ... . How can I not go mad through such long atrocious nights?"22 $\mathrm{He}$ even draws a picture of the double manacles used to shackle him in the bed at night. ${ }^{23}$ Only much later will Dreyfus find out the reason for this extra act of cruelty against him: in a ploy to force the issue of his wrongful imprisonment to the fore, Alfred's brother Mathieu arranged for a Welsh newspaper to report an attempted escape from Devil's Island, and when this false news reached France and the anti-Semitic press picked it up, the government reacted by imposing new conditions on Alfred's treatment in exile. ${ }^{24}$

Along the way, no matter what other matter he may write about in both the journals and the letters, Dreyfus complains of books and newspapers not reaching him or arriving very late, long after Lucie tells him that she had posted them to him. Most of the time, note, it is Lucie who chooses the titles, based on general hints given by Alfred, but also, as we have earlier suggested, titles selected from her knowledge of his tastes and interests and also probably on the shared conversations conducted in the first happy years of their marriage and courtship. In a supplement to his letter dated 12 September, 1896, Alfred recalls fireside chats with Lucie in the happier days of their marriage:

Je viens to causer encore, comme dans cet heureux temps, hélas déjà lointain, où nous bavardions tranquillement au coin de notre feu, en regardant jouer sur le tapis nos chers petits amours, nos enfants. ${ }^{25}$

149.

191 September 1896: “Je suis comme cristallisé dans ma douleur . . ." Cinq années de ma vie, 152.

202 September 1896: "Les nerfs m’ont fait horriblement souffrir toute la nuit ..." Cinq années de ma vie, 152.

213 September 1896: "Nuit horrible de fièvre et de délire" Cinq années de ma vie, 153.

227 September 1896: “J' ai été mis aux fers hier au soir! Pourquoi? Je l’ignore.... Comment ne suis-he pas devenu fou dans la longueur de cette nuit atroce?” Cinq années de ma vie, 155.

23 Cinq années de ma vie, 159.

24 A reader of this paragraph in manuscript shouted in anger and frustration, "Why on earth was Mathieu meddling in such a way? Couldn't he have imagined the consequences?" Alas, no he couldn't have. This was another failure of the imagination, another miscalculation in the strategy, driven by its own frustrations and rage.

25 Ecris-moi souvent, écris moi longuement, 315. 
I have just been speaking to you again, as in that happy time, alas so far distant, when we would chat peacefully in the corner by the fire, looking at our dear loves, our children, playing on the carpet.

A sentimental picture, to be sure, yet an idealized image of what must actually have been their custom at home. This is the time ${ }^{26}$ when they could share feelings and ideas and thus lay the groundwork for the structure of the new kind of relationship and new kind of domestic language they would have to construct during the long ordeal ahead. ${ }^{27} \mathrm{Al}-$ fred catches a hint of that preliminary labour in the same letter when he tells his wife, using long, involved syntax,

Vois-tu, chère Lucie, nous avons été tellement accablés par cet affreux destin-oh! l'affreux destin-oh! si horrible que l'on se demande à chaque instant comment nos cerveaux ont pu y résister-puis nous avons continué à nous entretenir de nos souffrances, de toutes nos douleurs, ne pouvant ${ }^{28} \ldots$

Don't you see, dear Lucie, that we have been so crushed by this frightful destiny-oh! So horrible that we have to ask ourselves at every instant how our brains could be able to resist it - then we have carried on our mutual support through our sufferings, all our pains, only being able...

On time in Jewish thought, see Ouaknin, Le livre brûlé, 120.

27 Conversation in rabbinical writings involves mutual questions and answers, challenges, probing, and revelations through exploration of what one's master and student or between the study partners: what one asks and what one says in reply is never wrong but always in the process of becoming a part of the chain of a self-correcting and expanding tradition; this is called mahloquet, and as modern commentators like Ouaknin and Faur write, it creates an open dialectic. These, however, are not the set-piece dialogues between Socrates (Plato's master and his docile interlocutors who quickly accede to his higher wisdom and declare, "We knew nothing; we do not know what we are talking about." Above all, says Ouaknin, mahloquet "est une façon de dire et de penser le réfus de la synthèse et du système; antidogmatisme qui, seul, rend possible une vérité vivante" (is a way of speaking and thinking the refusal of synthesis and system; an anti-dogmatism which alone makes possible a living truth), Le livre brûlé, 134.

Ecris-moi souvent, écris moi longuement, 315. 
These internal conversations in his mind are not only with himself but also, through his imagination, and through the force of mutual wills, in an imaginary space of textual union, for he speaks not only of his own cogitations but as though Lucie were also really and truly a party to these mental discussions and to the emotional and spiritual support they produce. But as the sentence meanders and the syntax falters, ${ }^{29}$ Alfred begins to think that there is more to the case against him than merely an error of judgement by the courts, the military, and the government, something he cannot bring himself to say, ${ }^{30}$ even to Lucie.

Que nos cours se sont aigris, à notre insu, malgré nous, et au lieu de ne penser qu'à une chose, ne voir qu'une chose, déchiffrer, faire déchiffrer le mystère de cet effroyable drame, au fur et à mesure que le temps passait, sans en amener l'êclairissement, nous avons fini par accuser d'un nouveau vouloir, veux mêmes qui font peut-être ce qu'ils peuvent pour cela ... et à ce système, tout finirait par se délabrer en nous, et il ne faut pas, chérie, il faut voir plus haut. ${ }^{31}$

[So that only] our hearts are irritated, without our realizing it, despite ourselves, and instead of thinking of one thing only, of only seeing one thing, to decipher, [and] are led to this frightful drama [being] deciphered, more or less, as the time passes, without leading to any enlightenment, we finish by blaming even those who perhaps can wish for that ... ill will and at this system, all will finish by falling apart on us, and this must not happen, darling, we must look higher.

29 According to Oaknin, "Dans la phrase hébraïque les mots ne sont pas subordonnées les uns aux autres par une logique grammaticale ou autre, ils 'coexistent', les uns auprès des autres et peuvent à [tout] l'instant signifier en dehors de leurs contextes ou être déplacé dans un autre contexte, tout en gardant les sens du premier contexte" (In a Hebrew phrase words are not subordinated to each other in one grammatical logic or another; they 'coexist' one alongside the other and may at any moment signify outside of their contexts or be displaced into another context, all the while keeping the sense of their first context), Le livre brûlé, 145. I do not mean that either Alfred or Lucie mean to write like this but that their education at its most basic level, in which the modalities of language are formed, slip into such constructs under sustained crisis conditions.

30 Not only is it difficult for him to conceive of these things, he finds it difficult, as we can see here in the confusing syntax, to put down in words.

31 Ecris-moi souvent, écris moi longuement, 315. 
Thus, what began with a sentimental scene of domestic bliss reaches its conclusion in a despondent picture of moral collapse, and a frightful prospect of something he wants Lucie to reject with him by turning their inner gaze towards heaven - the scene of the infernal phantasmagoria projecting the worst anti-Semitic images over all of France. ${ }^{32}$ Most of the time, however, at least in the letters and notebooks that have survived-or have been allowed to survive-Dreyfus maintains his appearance, keeps wearing the face of the loyal officer, and keeps the faith to Lucie, his muse and starlike guardian. The illusion he wants to hold on to is of their shared dreams and aspirations and of their mutual concern for each other and for the honour of their children.

After 1896, Lucie was told she could no longer pick and send books and magazines to her husband, but must instead remit funds for him to use to make his own orders through the penal system in French Guyana. ${ }^{33}$ It would seem that this new policy served several purposes: first, it takes away from Lucie the opportunity to do something practical on behalf of Alfred, which like the actual tactile possession of letters written in the hand of each of the couple was interfered with to cause emotional distress; second, the authorities may have believed in their bigotry that Lucie's choice of books was some form of code, part of a Jewish, mystical conspiracy; and third, by channelling the book orders through the officials of the prison and colonial systems, these agents thought to add another layer of censorship over what the prisoner would be able to read. Only in the retrospective calm of his explanatory essays of Five Years of my Life does Dreyfus begin to name the specific titles. In chapter VIII, he outlines his programme of readings:

32 Romain Rolland, speaking of a M. Félix Weil: "He flung out ideas and created lines of thought: he would set great intellectual machines working, and would immediately grow disgusted with them. More than once he had scandalized people, who had been converted to a cause by his arguments, by producing the most incisive and discouraging criticism of the cause itself" (Jean Christophe, vol. II, 351).

3318 July 1896: “J'ai regret, mon chéri, de n'avoir plus la liberté de t'envoyer des livres. M. le ministre m'a fait savoir que tu étais autorisé dorénavant à faire toi-même ton choix" (I regret, my darling, that I am no longer at liberty to send you books. The Minister has let me know that you are authorized from now on to make your own choices) Ecris-moi souvent, écris moi longuement, 307. This, of course, is a horrible, cynical joke played by the authorities. He was no more to do anything like ordering books than strolling around the compound to look at the sea or observe the flowers growing on the island. 
Ce fonds comprenait, outré un certain nombre de revues littéraires et scientifiques, quelques livres de lecture courante, les Etudes sur la littérature contemporare de Schérer, l'Histoire de la littérature de Lanson, quelques oeuvres de Balzac, les Mémoires de Barras, la petite Critique de Janin, une Histoire de la peinture, l'Histoire des Francs, les Récits des temps mérovingiens d'Augustin Thierry, les tomes VII et VIII de l'Histoire générale du IV siècle jusqu'à nos jours de Lavisse et Rambaud, les Essais de Montaigne, et surtout les oeuvres de Shakespeare. ${ }^{34}$

Many of these titles and authors are commented upon in the cahiers of Devil's Island, while the others are hinted at by vague allusion. These books named here consist mostly of school texts, anthologies, and general introductions to history, literature, and painting. In a letter of 11 June, 1895, Alfred writes to Lucie about several magazines he has been able to obtain: "On me remet la Revue des Deux-Mondes, la Revue de Paris et la Revue Rose," and then adds the wish that she send him "quelques romans de lecture facile" (some easy-to-read novels). ${ }^{35}$ It would be wonderful to know what he meant by this and what titles and authors she may have sent to him. Duclert claims that Alfred was allowed to receive twenty books each trimester, so that over the five-year period he might—had the jailers so permitted—have had access to at least three hundred titles. ${ }^{36}$ The wide range of titles and writers in the cahiers indicates, as we shall see when we discuss the kind of intellectual he was, that Dreyfus not only read more extensively than he hints here but that he wished to read more extensively still. It is important to recall that for the first few years Lucie chose the books to send him, and that

34 Cinq années de ma vie, 165-166. "This collection consists of a certain number of literary and scientific journals, some books of current reading, some of [Edmund Henri Adolphe] Schérer's [1815-1889] Studies on Contemporary Literature (1886). Lanson's History of Literature, some works by Balzac, the Memoirs [1896] of [Paul, vicomte de] Barras [1755-1829] , [Jules Gabriel] Janin's (1804-1874) Brief Critique (1886), a History of Painting, a History of the Franks, [Jacques Nicolas] Augustin Thierry's [1795-1856] Tales of Merovingian Times (1840). [Ernest] Lavisse and [Alfred Nicolas] Rambaud's [1842-1905] [Volumes VII and VIII of General History of the Fourth Century to Our Own Times (12 vols. 1893-1901)], [Michel de] Montaigne's [1533-1592] Essays [ed. 1877], and above all the Works of Shakespeare."

35 Ecris-moi souvent, écris moi longuement, 245.

36 Duclert, V, 1896, "La detention, la double-boucle, l'enfermement," Ecris-moi souvent, écris moi longuement, 283. 
afterwards when the packets ceased to arrive Alfred drew more deeply from his memory. The complaints he makes show that many-most?of what he hoped to receive never arrived at all. It is also likely that many of the authors, titles, and topics discoursed upon derived from memories of school study (from lycée through military college) and family discussions. Of Shakespeare, Dreyfus adds, "I had never understood this great writer so well as during this tragic period [of my own life]. I read and re-read him. Hamlet and King Lear appeared to me in all their dramatic power." ${ }^{37}$

Another list mentioned by Vincent Duclert is one of various journals, letters, and other papers supposedly returned to Dreyfus in 1900 after much effort, including most surprisingly: "4 Bibles, 2 Nouveau Testament, 3 paquets contenant des brochures de Sermons." ${ }^{38}$ The unexpected biblical material and sermons suggests, however, that these papers were not part of Dreyfus's personal readings during his stay on Devil's Island but materials sent to him by Christian missionary groups. This may have been normal for all prisoners, but for Dreyfus, such conversionary brochures and New Testaments would have seemed like gross insults, something confirmed by their absence from the captain's own list in his publications. Another document mentioned by Duclert but not found elsewhere is "un cahier iconographique,"39 mysterious because all of the surviving cahiers contain large numbers of the doodles that could conceivably be called iconographique, unless this is a reference to the one very early notebook discovered by Maxime Préaud in Colonial Museum in Aix-en-Provence and called the Cahier d'Aix. ${ }^{40}$ When we discuss Dreyfus's drawings in the next volume, we will examine the differences between these lost cahiers and the fifteen deposited by the captain in the Bibliothèque nationale. We will also consider in what sense these doodles may be considered iconographic - that is, having symbolic meanings individually and in clusters.

Interesting as the 1905 selection of letters and journal entries may

“Je n'ai jamais aussi bien compris le grand écrivain que durant cette époque si tragique' je le lus et relus; Hamlet et le roi Lear m'apparurent avec toute leur puissance dramatique" Cinq années de ma vie, 166.

38 Duclert, "Introduction," Ecris-moi souvent, écris moi longuement souvent, 55. This list is noted as coming from a Lettre du ministre des Colonies à Alfred Dreyfus, 20 octobre 1900 (CAOM, 133 MIOM 5," 55, n.3).

39 Duclert, "Introduction," Ecris-moi souvent, écris moi longuement souvent, p 58.

40 Maxime Préaud, "Variations à perpétuité" in Alfred Dreyfus, Cahiers de l'île du Diable, ed. Pierrette Turlais (Paris; Editions Artulis, 2009), 251-255, including several pages of photoreproductions. 
be in its own historical moment, since most of Lucie's have been excised and Alfred's own epistles carefully edited down, our emphasis now will be on the new edition of their mutual correspondence, because in this exchange over such a long period of time-although the latest editors have once again chosen not to put in all the letters, selecting mainly those by Lucie or Alfred that were stopped by the prison censors-because it is precisely in their repetitiousness and in their lack of direct coherence that many of the most interesting features of their individual personalities and of their mutual relationship are revealed.

The Souvenirs et correspondance ${ }^{41}$ of his father, selected, edited, and commented upon by Pierre Dreyfus in 1936, adds several more letters than are to be found in Cinq Années, Alfred now being dead and the whole affair becoming an historical memory rather than a burning current issue. Divided into three sections, this new presentation of Alfred Dreyfus's life, career, and writings, while somewhat fuller than that of the earlier book, still frustrates in many ways. To begin with, the first part, "La vie du Capitaine Dreyfus exposée par son fils, 1859-1899," tells us virtually nothing about Pierre's own recollections of his father, mother, or family, either what he heard from his parents or other relatives or what he experienced as a child growing up in the midst of the affair and its aftermath. ${ }^{42}$ The second part, "Les souvenirs du Capitaine Dreyfus 1899-1896," is mostly a reproduction of Cinq Années. However, the third part, "Les dernières années 1906-1935," brings in new information. The commentary that follows now concentrates, as does the rest of my book, not on the historical questions that still plague the student of the trials of Alfred Dreyfus and their impact on French society but on what these documents tell us about the man, his milieu, his mentality, and the midrash of his life.

In his Préface, Pierre Dreyfus (who never openly names himself except by the initials PD) gives a quick sketch of his father's personality, which I will gloss sentence by sentence:

41 P[ierre] D[reyfus], ed. Alfred Dreyfus, Souvenirs er correspondance, publié par son fils (Paris: Bernard Grasset, 1936).

42 Bloch-Dano: "La cohésion du groupe vient de ce temps où, à l'écart de la société de ses institutions, les Juifs n'avaient d'autres ressources que celles du groupe familial. Plus ce groupe était puissant, plus l'individu était protégé" (The cohesion of the group comes from a time when, kept apart from society and its institutions, Jews had no other resources than those of the family group. The more powerful was this group, the more the individual was protected) in Madame Proust, 105. 
Mon père qui, par nature, n'était pas d'un caractère très expansif, avait été marqué encore par cinq années de tortures et de solitude absolue et s'était concentrée sur lui-même. ${ }^{43}$

My father, who was not by nature a very expressive character, had been marked by five years of torture and absolute solitary confinement and had drawn into himself.

By nature, that is, in essence, although as our discussions show, this quality of his personality is more complex than Pierre allows for and is partly a consequence of his upbringing as a Jewish refugee from Alsace separated from most of his family. These three qualities are significant in themselves and more intense through the conjunction in a young man suddenly subject to intense external pressures as the Jewish alien at a time of rising anti-Semitism, as well as being the deracinated youth growing up under tense personal and public pressures and perhaps also as the one male sibling brought up by older sisters when his brother was not. What did he do? He chose the most untypical profession for a Jew-a soldier; this was also the most masculine of professions, which that removed him from the female environment.

These choices, whether made freely or under family pressures, exacerbated his not very expansif character. The range of translations given for the word expansif includes communicative, demonstrative, exuberant, confident, frank, and open. In other words, from the range of antonyms, what his son Pierre says is that his father was reticent, reserved, and taciturn, although not timid or hesitant. Alfred Dreyfus was often perceived to be cold, withdrawn, unfeeling, lacking in both inner grace and external poise-and was called later by unsympathetic witnesses "the zinc marionette." I have suggested that this public perception, noted as much by friends and supporters of Alfred as by his political enemies, was a role of "delegated madman" in the Grand Guignol of the affair. ${ }^{44}$

43 Dreyfus, Souvenirs, 13.

44 It seems no accident that the theatre founded with this name to perform melodramatic horror shows should prove a success in Paris from 1897 on, the date of the height of the affair. Guignol had been the name of a popular local hand puppet in Lyons, and his name had become a common term for a type of fool who was involuntarily the object of ridicule because of his awkward movements and lack of social graces. 
These characteristics may have been exaggerated, as the son explains, by the tortures undergone by his father, but also brought out some very minor symptoms of autism in young Alfred..$^{45}$

Il vivait une vie intérieure intense, mais ne savait plus guère extérioriser ses sentiments. ${ }^{46}$

He lived an intensely interior life, but he hardly knew how to externalize his feelings.

This intense interior life that Pierre points to should be understood as marking the thoughtful, intellectual side of Alfred Dreyfus, a designation of his profound strength in being able to withstand so many years of physical and psychological torture by being able to withdraw into a world of philosophical ideas and discursive memories. If he was not able to express his feelings openly in such a way as to win the approval of the great public or even to evoke sympathy in his accusers and judges, he could maintain his dignity, as indicated by his proud proclamation of his innocence over and over again, not least when he was marched through the troops assembled to watch his degradation in 1894 or when he held himself erect and silent in the face of the hostile second court-martial in Rennes in 1898.

Il avait perdu l'habitude de les exprimer, et comme par ailleurs il répugnait à se plaindre, à exposer en public ses souffrances, il paraissait très distant à ceux qui les connaissaient peu. ${ }^{47}$

He had lost the habit of expressing them, and yet how he loathed to complain about himself, or to expose his sufferings in public; he seemed very distant to those who barely knew him.

45 This form of posttraumatic stress syndrome (PTSD) will someday have to be discussed, not only as it helps explain Dreyfus's behavior at the time of his arrest, trial, and condemnation, along with his lengthy period of imprisonment, exile, and isolation, but also the appearance he made upon his return to France and then his decision to retire from the army and lead a retired, private life.

46 Dreyfus, Souvenirs, 13.

47 Dreyfus, Souvenirs, 13. 
He had lost his customary ability to express his feelings, writes Pierre, assuming that prior to his arrest and condemnation, his father had been more normal in the demonstration of his sentiments; yet close reading of the surviving documents, including those of friendly and bigoted prison officials, suggests that there were many moments, usually when he thought he was alone, or at least not under public scrutiny, when Alfred became enraged, threw himself against walls, and screamed in pain and frustration. Many of his letters also reveal a constant struggle to keep himself from losing all self-control, lapsing into wild tantrums, or falling into despondency and immobility. Alfred more than once writes to Lucie that she knows how fragile are his nerves and therefore how close to madness he has always felt himself to be. Aware too of the common slurs against Jews as nervous, weak, and timorous, Alfred has always done all he could to project a version of himself that is steady, strong, and brave. Almost never does he cry out in pain to anyone other than Lucie in what he hopes will be the privacy of their epistles, believing that showing such a reaction to his suffering will give comfort to his opponents and confirm in the eyes of the hostile public the unsuitability of a Jew to be a soldier-citizen of France. This is part of his honour, the duty he owes to the army and the republic, and the heritage he hands on to his children. However, Pierre knows that the coldness seen by those with little acquaintance with his father is not the true character of Alfred Dreyfus.

In his narrative of the accusation, arrest, and trial of his father, Pierre seems to pass over with barely a mention the most important factor, what he rightly-but without careful analysis of the words he uses and the phenomenon he refers to- "the virus of anti-Semitism," the monster that bores within the body politic and there picks out its scapegoat, "the abhorred Jew." ${ }^{48}$ He can cite a letter of 28 October, 1894, from Colonel Joseph Henry to the anti-Semitic newspaper Libre Parole of Edouard Drumont announcing that "Tout Israël est en mouvement" (The whole of Israel is on the move) $)^{49}$ and yet not take it as more than a minor annoyance, an incidental factor in the case against his father. These more neu- 
trally termed "haines religieuses" (religious hatreds) ${ }^{50}$ do not seem to him to constitute the very essence of the case. He does not see that an actual crime has not been proved, or at least not one of such significance as to warrant the charges laid against his father. Like others in the family and inner circle of their friends, he cannot imagine why the investigation to find the German spy terminated when a Jew was found to play the necessary role of scapegoat, thus satisfying petty jealousies amongst junior officers and the prejudices of officials in the high command and the Ministry of War. In outlining his father's life history, Pierre Dreyfus merely identifies Alfred as "of Israelite origins" (d'origine israëlite) ${ }^{51}$ and does not even do as much with Alfred's chosen wife, "Mlle Hadamard, fille d'un négociant en diamants, et petite-fille du capitaine Hatzfeld, ancien élève de l'Ecole Polytechnique (promotion 1835)."52

Pierre, like his father, seems to assume that because religion is of minor importance in their lives-but this may not have been true for Lucie, as we shall see-it was not really important in the jealousies and arrogance roused by the affair. ${ }^{53}$ Not even when Pierre cites an openly anti-Semitic remark made by one of the group involved in organizing the conspiracy does it strike him that such a calumny might be the driving force of the whole case against his father. Yet that conspiracy was not planned out step by step over many years or months but was rather an ad hoc arrogant response to the opportunity of finding a scapegoat, and then the manipulations became more and more byzantine when the opposition by the family and friends of Dreyfus was observed to challenge the authority and credibility of the army and the government; each new step taken took on the colouring of the latent anti-Semitism in the persons and the institutions involved in the cover-up. How could the system have responded to the initial lies and errors?

50 Dreyfus, Souvenirs, 34.

51 Dreyfus, Souvenirs, 40.

52 "Miss Lucie Hadamard, daughter of a diamond merchant, and granddaughter of Captain Hatzfeld, former student of the Ecole Polytechnique (commissioned in 1835)" Dreyfus, Souvenirs, 42.

53 David and Louise Hadamard brought their daughter Lucie Eugénie up to be a good Jewish wife. Burns writes: "As tall as Alfred, with thick dark hair parted in the middle and pulled back with a bandeau to control her curls, and with brown eyes, broad shoulders, and a slim waistline made slimmer by the tight lacing of the day, Lucie [she was nineteen when she met Alfred] had been raised at her family's country home at Châtou, near Paris." The information available concerning her education is spare and tantalizing: "She may have attended the private Ecole Monceau where one of her sisters had been a student, but tutors and family members directed much of her education" (Burns, Dreyfus: A Family Affair, 79). 
Here, for instance, is how Colonel Picquart, himself no great friend of the Jews, but a man of honour, was handed an insult to his intelligence. After he pointed out to his superiors that the handwriting on the incriminating documents presented to bolster the case were similar to each other but not to Dreyfus's, and even that Dreyfus has been locked away for a year, he was confronted by this absurdity from his superior officer:

Et comme Picquart crut devoir faire remarquer qu'il s'agissait d'une correspondance récente, Bertillon répliqua sans sourciller: "Alors, c'est que les Juifs ont exercé quelqu'un depuis un an pour imiter l'écriture, ils sont arrivés à l'identité."

And as Picquart believed it his duty to remark that it was a question of recent correspondence, Bertillon replied without flinching, "Well, it's the Jews who have over the year found someone to imitate the handwriting and now they've got it down pat."

Rather than a clash of cultures or religious apprehensions of reality, the confrontation is between prejudice and judiciousness, ignorance and common sense, and bigotry and tolerance. The choice, then, has to be whether the Dreyfus's opponents were stupid, naive, arrogant, or evil-that is, whether the misapprehensions and misprisions arose from an inability to comprehend the facts and circumstances, from an unwillingness to question authority and its official line of argument, from a resistance to giving any value to what was said or done by persons considered inferiors and interlopers, or from a sheer perverse wish to hurt or humiliate others. There probably were a few individuals who had secret agendas to work through and who took the opportunity of Dreyfus's presence in a sensitive position to deflect suspicion away from themselves or their allies, but that does not explain the length of the resistance to the truth nor the pervasiveness of the willingness to accept patently absurd claims as the truth.

This kind of misapprehension seen operating throughout the Dreyfus Affair arises through a false reduction of the concept of religion to a matter of personal beliefs and private feelings, one where theology and 
religious practice are moved to the margins of modern, secular experience. Arguing or feeling this way creates a situation in which there is an epistemological impasse or crisis. How so? Well, on one side, there are those parties to the affair for whom religion is everything-a Weltanschauung, a mythical imagination, a racial quality separating every nationality, cultural group, language cohort, community, and regional culture-and, on the other, those for whom religion is so trivial that they try to avoid seeing its manifestations in themselves or in their neighbours or enemies. It is not a question of Pierre or Alfred Dreyfus not knowing that Judaism and anti-Semitism were relevant factors in the whole ordeal but that the intensity and seriousness of that relevance did not register fully. Hence, the two groups of partisans talked at crosspurposes, contended in politics and social rivalries without noticing the grid of blind spots between them, and misinterpreted their supposed victories and defeats. This is not just a matter of eviscerating religions of all their aesthetic, spiritual, and intellectual richness but of mistaking the motivations and consequences of their own mutual actions and achievements. Here is a passage that supposedly reveals another dialogue between some of the conspirators:

Du Paty, Henry et Gribelin s'y rendirent, mais Henry resta caché. Du Paty expliqua à Esterhazy les machinations des Juifs et l'assura qu'il pourrait compter sur des défenseurs résolus s'il était prêt à obéir aux instructions qui lui seraient données. ${ }^{55}$

Du Paty, Henry and Gribelin went to the place, but Henry remained hidden. Du Paty explained to Esterhazy the machinations of the Jews and assured him that he could count on resolute defenders, if he were prepared to obey the instructions which would be given to him.

It should be obvious that the conspirators are manipulating Esterhazy ${ }^{56}$ the real spy and traitor who is selling minor secrets to the

56 Compare the satirical version of this manipulative and duplicitous action in Anatole France's short story Emile: "And here Zoé, we approach a scene in the comedy of life, the melancholy humor of which may one day be appreciated. During the Dreyfus Affair it occurred to Emile Vincent [i.e., Zola] to say that Esterhazy was a fraud and a traitor. He said it because he knew it was so 
Germans because he needs the money to pay for his mistress and his gambling debts, and who actually hates the French—he writes in a letter later that he dreams of leading mounted Hungarian Uhlans into Paris to slaughter hundreds of thousands of French men and women. ${ }^{57}$ So he was not motivated by simple, stupid greed or bribed by the dark forces lurking behind this petty intrigue. The others, the highly-placed military men, however, seized the occasion to get at Alfred Dreyfus because they resented him as a Jewish upstart, and then, once started in this plot, they are drawn by their own arrogance to elaborate upon the deception more and more, finding their own hatred of Jews the path of least resistance to gaining support in the rest of the army, the government, and French society. But this is not obvious to the writer of Souvenirs et correspondance: he sees the arrogance and the stupidity but not the endemic and persistent anti-Semitism. He knows that what is going on is a "simulacrum," ${ }^{8}$ but not how it works or what motivates it. Alfred goes further and writes on 23 January, 1895, from Devil's Island:

Il semble que je suis le jouet d'une terrible hallucination, que tout cela va se dissiper. . . mais hélas! la réalité est tout autour de moi. ${ }^{59}$

It seems that I am the plaything in a terrible hallucination, that all of that is going to fly off into nothingness ... but, alas! reality is all around me.

He too, like his son and his other supporters, is so close and so far from understanding what is happening. Soon after, Alfred writes to " $M a$ chère Lucie" on 14 February, 1895, that he believes and hopes that in the future, "quand on rancontera mon histoire, elle paraître invraisemblable,"60

and because he was far too candid ever to conceal the truth. From that day he was regarded as the enemy of his country and of the army. He was treated as a traitor and an alien" (France, Crainquebille Putois, Riquet and other Profitable Tales, 126).

57 Remember that moment near the end of book IV of Gulliver's Travels when Swift's maniacal protagonist revels in the thought that thousands of Houhymhms will set sail for Europe to seek revenge on the madness of these talking Yahoos and confront their massed regiments and crush them into gelatinous putty, a mummy. Esterhazy was as mad as Lemuel Gulliver but for no good reasons.

58 Dreyfus, Souvenirs, 102.

59 Dreyfus, Souvenirs, 113.

60 Dreyfus, Souvenirs, 119. 
when someone tells my story, it will seem unbelievable. However, these unbelievable nightmares and hallucinations are not a figment of Dreyfus's own mind but a mass delusion, a phantasmagoria, enveloping all of France and even the rest of Europe.

Three features of this process of deception and self-deception about Judaism and anti-Semitism can be seen in the letters that Lucie and Alfred write to one another that are published in their son Pierre's selective anthology. First, there are the casual and neutral uses of Christian terms, such as martyrdom (martyre), sacrifice (sacrifice), calvary (calvaire), and the stain of sinfulness (tache). ${ }^{61}$ They can also write about "une justice divine," 62 which they hope and pray will watch over them and solve the inscrutable enigma of the charges against Alfred. So far as the husband and wife seem concerned, these words are merely colorful expressions of their sense of pain and humiliation. They come with no sacramental, liturgical, or mythical resonance. ${ }^{63}$ If there is a zone of allusiveness in this lexicon, it is to the principles and ideals of the French Revolution and republic, generally to abstract truth and justice. Similarly, when they occasionally use the word God (Dieu) or faith (foi), it is as an exclamation rather than an appeal to the deity or a prayerful statement. Words like exile, saint, or martyr, which could have a Jewish connotation or a Christian signification, tend again to be neutralized terms of intensification of the secular pains felt by the husband and wife. More specific references to Jewish customs and practices are subdued and virtually unnoticed. ${ }^{64}$ For instance, Lucie writes on 30 December, 1894,

61 Benmozegh recalls "a principle of the Kabbalists, according to which 'all the foreign gods who are referred to in Scripture contain a spark of holiness"” (Israel and Humanity, 115).

62 Dreyfus, Souvenirs, 111.

63 "The philosophical study of the Hebrew language confirms in its own way this mystical explanation, by showing the genius of the language is to proceed directly to the fundamental idea without stopping at the verbal form, and that is one is perfectly entitled therefore to perceive the expression of divine qualities beneath the polytheistic names" (Benmozegh, Israel and Humanity, 115).

64 According to Michael Burns, who has examined the archives, personal and private, to discover all that seems possible to find out about the background of Alfred Dreyfus's mother and father and of the young boy's religious upbringing, “The Dreyfus family left no record of the children's religious instruction in Mulhouse; nor did the synagogue hold documentation of their formal schooling, if any. But if they learned the Hebrew required for the confirmation ceremony [bar mitzvah] — a ceremony of special significance for their observant parents - the children also had to learn the 'sacred declaration of patriotic loyalty' to France that accompanied the religious rite" (Dreyfus: A Family Affair, 39). Can we also assume that when a baby Alfred was circumcised and that he went to some sort of cheder for his earliest education in Jewish knowledge? As Burns sees, all such information remains conjectural and elusive, except that, as we are showing in our close reading of the letters and other documents extant of his life during the ordeal, Dreyfus has an implicit awareness of the basis 
C'est ce soir l'anniversaire de la mort de ton père, nous irons tous au temple. Pauvre grand-papa, en mourant, il ne connaissait pas son bonheur. ${ }^{65}$

This evening is the anniversary of your father's death, we are all going to temple. Poor grandpa, in dying, he did not know his own happiness.

In a later letter, Lucie brings to the surface the equivalence of "vérité = bonheur"66 (truth = happiness) This can be read in specifically Jewish terms: "Tonight is your father's yahrzeit [yearly memorial for him and his relatives] and we are all going to shul [synagogue] to pray. Poor zayda [grandfather] when he passed away didn't realize what mazel [luck] he had by not knowing of your arrest, conviction and exile." But the translation could render the terms in a less Hebraic way, without the inflections of Yiddish appropriate to Ashkenazi Jews: "This evening on the memorial day of your father's passing, the whole family will go to the temple (in the French sense of a non-Catholic house of worship) for a service. Poor Granddad, in dying before the events of your case became known, was saved private humiliations and public shame." On the thirtieth of December, 1894, Lucie again writes about this occasion but adds that she has gone to the temple with Mathieu to say kaddish (the prayer for the dead) for "le triste anniversaire de la mort de ton pauvre père" (the sad anniversary of your poor father's death), and then she adds still further, "Que de soucis, que de chagrins nous avons eus en une année. Quels malheurs épuvantables et immérités peuvent s'abattre sur une famille en si peu de temps"67 (What cares, what grief we have had in one year. What horrible and unmerited miseries could beat down on one family in so little a time). It is as though she wants to cry out in words that Alfred will recognize from the Passover haggadah (book of traditional rabbinic tales and songs), "Dayenu! Enough for us!"

Another more specifically Jewish allusion appears in a postscript to Alfred's letter of 12 March, 1895, when he tells Lucie "Quand tu auras une

of Judaism and an occasional explicit ability to articulate those beliefs and patterns of belief.

65 Dreyfus, Souvenirs, 51.

6612 August 1895. Ecris-moi souvent, écris moi longuement, 253

67 Ecris-moi souvent, écris moi longuement, 100. 
bonne nouvelle á m'announcer, envoie-moi une dépêche, je l'attends chaque jour comme le Messie"68 (When you have some good news to tell me, send me an urgent message, I am waiting for it every day as for the Messiah). Christians wait for the Second Coming, while Jews expect the Moshiach to appear at any moment-for the first time. Besides, the almost lighthearted and ironic mixture here shows the character of Dreyfus's neshama (his soul) more than any more ponderous or sanctimonious Christian expectation of the End of Days. Usually, as we shall discuss more fully when we deal with the latest edition of their letters, it is Lucie who lets slip the little Yiddishisms of her family, rather than Alfred, who, while not quite with the level of cynicism or bitterness against his background of Sigmund Freud arguing for his bride-to-be Martha Bernays to forgo her Jewish beliefs and practices, such as keeping kosher, has made an effort to assimilate himself to military life. Where her husband sees the forces ranged against him as part of some inexplicable enigma ${ }^{69}$ that has caused a judicial error, it is the wife who speaks in more traditional rabbinical terms of their joint martyrdom, although she also is shaping remarks around supportive echoes of what Alfred writes:

Dieu qui nous a si cruellement éprouvés nous donnera la volonté d'accomplir jusqu'au bout notre de devoir, de relever notre nom de la tache qu'on lui a odieusement jetée, et nous accordera la réparation éclatante sans laquelle ni nous, ni nos enfants, nous ne pouvons nous résigner à vivre. J'ai la conviction qu'avec une volonté de fer, une énergie indomptable et une persévérance à toute épreuve, on peut surmonter toutes les difficultés, on peut sonder tous les mystères . . . ${ }^{70}$

God who has so cruelly tested us will give us the will to reach the fullness of our duty, to remove from our name

68 Dreyfus, Souvenirs, 122.

69 Typical of his letters to Lucie, on 7 September 1895, Alfred writes: "Il faut avoir l'énigme de cette machination infernale qui nous a enlevé ce qui fait vivre et ce qu'il nous faut: notre honneur" (The enigma of this infernal machine must be found out so that we can live and have what we must: our honor); Ecris-moi souvent, ecris moi longuement, 258. Note how Dreyfus uses the "uncanny expression" (according to Norbert Col) rather than the more familiar idiom "avoir l'énigme"uncanny because it indicates how Dreyfus is being twisted out of his normal ways of speaking and thinking, unless this is an error in the transcript by editor Vincent Duclert.

70 Dreyfus, Souvenirs, 128. 
the stain that has been so odiously thrown on it, and will grant to us a brilliant reparation without which we and our children, we cannot resign ourselves to live. I am convinced that with an iron will, [so that with] an indomitable energy and an unflinching perseverance [we can pass through] through all experience, we can surmount all difficulties, we can get to the bottom of all the mysteries...

Then, swept up by the power of her own enthusiasm and again echoing and reinforcing Alfred's own self-encouraging words and phrases, she states:

La vérité peut éclater aujourd'hui comme elle peut éclater demain ou après. Personne ne le sait, Dieu fasse que ce soit le plus vite possible. Je ne puis te dire qu'une chose, mon bon chéri, c'est que la lumière se fera et que nous l'aurons pleine et entière. ${ }^{71}$

The truth may flash out today as it may break forth tomorrow or [in the days] after. No one knows when God will make it happen [and may it be] as quickly as possible. I can only tell you this one thing, my dear good husband, it is that the light will shine forth and it will be full and whole for us.

Note here how Lucie, herself the light, the Shekhina, resonates with the kabbalistic terms found in nineteenth-century Jewish liturgy and hence familiar to herself and to Alfred, even if they have never thought of the sources or implications of such language. The truth is a light that flashes out like lightning (zohar) when God wills, and thus, while we cannot know when it will happen, the emergence of this zoharistic clarification of mysteries is not unexpected. It will be a Day of Redemption, messianic in its glorious light, may it happen, as the formula goes: "speedily in our days." ${ }^{72}$ Then comes the tikkun ha-olam, the repair, the correction,

72 Ouaknin teaches: "Le livre est donc le lieu d'un paradoxe-ou d'une rencontre; il recueille l'Infini 
and the reunification of God and his Shekhina, which is Israel. ${ }^{73}$ It will prove the end of the Galut, exile, dispersion, suffering, and dishonour. In more plain and practical terms, as Alfred's brother writes on $25 \mathrm{Sep}-$ tember, two weeks later, "Dieu ne permettra pas qu'un innocent paie pour des coupables"74 (God will not permit an innocent man to pay for [the crimes] of those who are culpable). But none of them seems fully aware of the "machination"75 at work to keep the falsely accused exile locked away on Devil's Island).

Thanks to the lengthy delays between writing and receiving letters, it is only on 26 June, 1896, that Alfred answers the fervent hopes that Lucie has expressed of a divinely ordained release from torments:

Tu me dis aussi d'accepter la certitude que la lumière la plus complet serait faite sur ce lugubre drame. Non seulement, j'en accepte la certitude mais ma confiance, comme ma foi ont toujours été absolues; je connais trop bien les sentiments d'honneur qui animent tous les membres de nos deux familles pour avoir jamais pu en douter. ${ }^{76}$

You tell me to accept with certainty that the most complete light will shine on this lugubrious drama. Not only do I accept that with certainty, but my confidence, like my faith, has always been absolute, I know too well the sense of honor that animates all members of our

(Tsimtsoum), mais il dévoile immédiatement son incapacité à cet accueil en montrant que l'Infini ne peut se laisser englober, ne peut se laisser enfermer en une présence sur laquelle on pourrait avoir une quelconque emprise. Il y a alors débordement, et plus, éclatement (Chevira) du Livre en trois livres" (The book is thus a place of paradox-or of an encounter; it is gathers together the Infinite (Tsimtsoum), but it immediately reveals its incapacity in this welcome by showing that the Infinite cannot be englobed, cannot let itself be possessed by any act of domination or possession. There is then an overflowing, and more, the explosive shattering of light (Shevira) that shatters the Book into three books) in Le livre brûlé, 226.

73 According to Elijah Benamozegh, "Nowhere is God thought of as an isolated being which, having accomplished the work of creation, handed over control of the universe forever to the laws which He had established. These laws are regarded as the expression of an unending intercourse between cause and effect. They constitute the Divine as it exists here, the Shekhina, God inhabiting His creation," Israel and Humanity, 70.

74 Dreyfus, Souvenirs, 129.

75 Alfred speaks of "cette machination dont nous sommes les malhereuses et épuvantables victims" (this machination of which we are the unhappy and horrible victims): Dreyfus, Souvenirs, 130.

76 Dreyfus, Souvenirs, 137. 
two families ever to have any doubts.

However, what Alfred has absolute confidence and faith in is not exactly that which Lucie has written about. She has been speaking, at least partly, about a spiritual expectation of divine intervention, albeit a concomitant enhancement of human strength of character, while he, to keep away from the doldrums of despair and defeatism, writes of his indomitable faith in the loyalty of the families. It is true that as much as husband and wife have been tested and proved in the fires of this iniquity, so too the Hadamard and Dreyfus families have rallied to support Alfred and to give comfort to one another, both actions being things that commentators have found remarkable, because too often in similar circumstances marriages have broken apart, families have disassociated themselves from members accused of high crimes and misdemeanours, and individuals have broken - sought divorce, changed their abodes and names, undergone mental breakdowns, or committed suicide.

The faith that Alfred writes about is also religious but in a different way than Lucie's. For him, ironically as for his bitterest enemies, France is the sacred country and thus duty to her and her institutions are sacramental acts. ${ }^{77} \mathrm{He}$ also sees France as the supreme judge to which he submits his fate, not to any biblical version of God but to this "juge suprême," his fatherland, "la patrie." 78 As a shocking corollary to that, it is Alfred's personal honour that is of supreme value. It seems as though Lucie is only echoing his sentiments as part of the therapy she is conducting for him, but she makes explicit a thought that Alfred would suppress-and that she, in her normal state of mind, would find horrifying: that they would rather that their children were dead than have to live in disgrace: "J'aimerais mieux voir nos enfants morts que de penser que le nom qu'il portent est déshonoré"79 (I would rather see our children dead than think of the name they bear being dishonoured). This is his own horrible "culte de l'honneur." ${ }^{0}$ It seems Lucie, shaken by the violence of Alfred's treatment, attempts quietly to assuage his rattled nerves and help him turn towards

77 On 24 April 1897: "Et la réalité, las voici, toujours la même: c'ést que dans cette horrible affaire, il y a un double intérêt en jeu, celui de la patrie, le nôtre, que l'un est aussi sacré que l'autre" (And the reality here is always the same is that in this horrible affair there is a double interest in play, that of the nation, [and] our own, and that is as sacred as the other) Dreyfus, Souvenirs, 154.

78 Alfred to Lucie, 10 August 1897: Dreyfus, Souvenirs, 158.

79 Alfred to Lucie, 14 April 1895: Dreyfus, Souvenirs, 119.

80 Alfred to Lucie, 28 August 1898: Dreyfus, Souvenirs, 174. 
a more peaceful resolution to the great mystery confronting them. ${ }^{81}$

Yet, knowing as only she knows-the true state of affairs back in France being still vigorously censored by colonial and prison officialsthe need to keep this a secret is almost too much for her to bear. She fears that Alfred, with an already weakened body and mind, may not be able to withstand the new shock of positive news about a revision of his conviction. She knows his vulnerability because of the extreme statements he makes and also because, more than him, she has been observing from afar his mood swings and his detailed descriptions of the loss of sanity he fears. ${ }^{82}$

Moi, je ne vis que dans la pensée de la joie profonde à la pensé que tu auras en apprenant cette nouvelle, et je me souhaite des forces, un pouvoir surhumain pour te voir dans ce moment de satisfaction suprême. Pourvu, mon Dieu, que cet ébranlement si grand ne te soit pas funeste et que ton pauvre corps affaibli ne se ressente pas d'une telle secousse! !3

I can only live [or rather: see] in this thought of profound joy the thoughts that you will have on learning this news, and I wish that I had the strength, a superhuman power to see you at the moment of supreme satisfaction. Provided, dear God, that this great shock does not prove fatal and that your poor weakened body does not suffer from such a great blow!

It has been Lucie's duty, she understands, to provide Alfred with

81 More disturbing is the resonance here of the temporary changes in Jewish sensibility that occurred at the time of the First and Second Crusades, when parents and whole communities took the decision to sacrifice their children rather than see them taken from them, forcibly baptized, and brought up as Christians to hate their former selves. At that time, during the eleventh through thirteenth centuries, there was a midrashic reconstruction of the Akeda, the Binding of Isaac, to show Abraham so willing to slay his son on the altar, that when God restored the youth unharmed from the ordeal, the father killed him again. At times, Sarah, who is usually kept away from the performance of the deed God has commanded Abraham because of her maternal sensibilities, emerges as an active participant in the Kiddush ha-Shem, the Sanctification of the Name.

82 She also knows his previous demonstrations of nervous irritability; she also has known since their days of courtship when Alfred's letters warned her of these tendencies and begged her to be patient and sympathetic with his appearance of coldness and rages. These matters will be discussed later in reference to the imposed autism seen in Alfred after his return to France in 1899.

Lucie to Alfred, 26 September 1898: Dreyfus, Souvenirs, 175. 
the feedback he needs to keep up his strength and resolution, but also, insofar as she can in the midst of her own problems-her separation, her need to overcome the bourgeois Frenchwoman's reluctance to play a public role in politics, her shyness as a Jew to appeal to hostile government and legal officers, her need to hide from the children her fears and worries for their missing father (she tells them he is on a long trip as part of his soldier's duty), and her instinctive need to keep from exacerbating his sense of isolation or raising his hopes too high before any confirmation of social change can be addressed to him-to lead him gently toward a state of mind conformable to his own real character. This complex task becomes even more difficult in the final days of his imprisonment before his return to France, because the wheels of justice turn so slowly and the complete information on his current status is deliberately obscured by the same cruel and devious agents who have managed his whole experience on Devil's Island. ${ }^{84}$

The story of what happens to Alfred and Lucie just before, during, and immediately after the second conviction at Rennes will be integrated into discussions in further chapters of this book and those that follow, just as we will put off for the moment a close reading of their letters in the modern edition and the new edition of the journals Alfred kept between the time of his pardon and his rehabilitation. The focus, however, will be less on the political or judicial side of the story than on the personal. For even more than the strong active engagement by both $\mathrm{Lu}-$ cie and Mathieu in pursuing legal rectification of the judicial errors and later the crimes revealed, it is the special relationship that Captain and Madam Dreyfus established in their letters that amazes more than any other phenomenon in the whole affair. As we shall see in later volumes in this series, perhaps the most amazing thing of all is the intellectual reconceptualization of Alfred in his prison notebooks. Before that, more groundwork in preparation for those discussions has to be laid, or in midrashic terms: we have to look at the textures, contextures, antitex-

84 How cruel the jailers were is explained by Duclert in an introductory section to the last stages of Dreyfus's imprisonment on Devil's Island: "Il n'imagine pas que tous ses appels ont été systématiquement ignore et qu'il a fallu une mobilization publique sans precedent pour que ceux de sa femme soient finalement entendus par le gouvernement" (He did not imagine that all his appeals were systematically ignored and it would be necessary to mount a public mobilization without precedent by those [appeals] of his wife finally to be heard by the government) (Ecris-moi souvent, écris moi longuement, 401). 
tures, and untextures of these two further bodies of evidence. ${ }^{85}$

\section{PART 2: ALFRED AND LUCIE'S LOVE LETTERS}

En Pologne, la mazoure devient souvent le lieu où le sort de toute une vie se décide, où les cours se pèsent, où les éternels dévouements se promettent, où la patrie recrute ses martyrs et ses héroünes. En ces contrées, la mazoure n'est donc pas seulement une danse; elle est une poésie nationale, destinée, comme toutes les poésies des peuples vaincus, à transmettre le brûlant faisceau des sentiments patriotiques, sous le voile transparent d'une mélodie populaire. Aussi, n'y a-t-il rien de surprenant à ce que la plupart d'entre elles modulent dans leurs notes et dans les strophes qui y sont attachées, les deux tons dominants dans le cour du Polonais moderne: le plaisir de l'amour et la mélancolie du danger.

$$
\text { -Franz Liszt }{ }^{86}
$$

But it is precisely in the space between the literal meaning and the legal ruling that the experience of Talmudism is to be found. After rudimentary explanation of words and concepts, after the judicial extrapolation of practices and regulations, the dance of reason begins.

—Leon Wieseltier ${ }^{87}$

This section of the chapter will argue that the letters between Alfred and

85 As [Ithamar] Gruenwald notes, the "midrashic condition" is a mental attitude that entails the creation of meaning rather than concern for the lexical or philological understanding of a text" (Wolfson, Through a Speculum that Shines, 331, n. 19), and one might add of the historical or generic character of that same text.

86 F. Liszt, F. Chopin, 4th ed. (Leipzig: Breitkopf et Haertel, 1890). Chapter III. "In the mazurka the bold and vigorous colouring of the polonaise gives place to the most delicate, tender and evanescent shades; it is not the nation as a whole, in a united, single and characteristic impetus, which is brought before us, but the character and the impressions become purely personal and are always individualized and divided" (Franz Liszt, Life of Chopin, 2nd ed., trans. John Broadhouse (London: William Reeves), 86).

87 Leon Wieseltier, “Unlocking the Talmud's Secrets: Thoughts on the Steinsaltz Talmud in English" The New York Times, Sunday Book Review (17 December 1989), reprinted by David Sasha on Sephardic Heritage Update (11 November 2010) on the occasion of Steinsaltz's completion of his translation of the whole Talmud online at davidsasha@googlegroups.com (seen 11 November 2010). 
Lucie Dreyfus are in themselves a kind of frenetic and, at the same time, subtle dance, an interchange and a mutually supportive sharing of ideas, feelings, and dreams. ${ }^{88}$ Franz Liszt's romantic effusions on Chopin's life and music — they are one, in his mind-also provide interesting insights that can be applied, albeit with proper adjustments to the different times, places, characters, and intellectual and political contexts, to the interwoven and superimposed nature of the epistles between husband and wife. Although he was an anti-Semite, Liszt succeeded, as A. Z. Idelsohn points out, "in penetrating into Israel's spirit." ${ }^{89}$ Taking the occasion of the mazurka in a metaphorical sense as both a figure of longdistance social relationships and longed-for emotional and intellectual encounters, what Liszt says in his own voice and that of other characters opens up the obscure region of the Dreyfus letters. For instance, when the older musician writes,

Here chance may bring into contrast those who a few hours before were perfect strangers to each other. The ordeal of a single moment, a single word, may separate long united hearts; necessity often forces sudden confidences and invincible suspicions kept close in the mind. ${ }^{90}$

The reader of those desperate letters penned across the Atlantic Ocean, arriving out of order, held back for three or four months at a time, sees the correspondents forced by circumstances and intense longing to fear the worst, hope for the best, and seek to grasp some tangible echo or ghost of a remembered image to reassure the other and the self of their love, their loyalty, their courage to carry on, and their trust in an eventual resolution to the oppressive enigma that keeps them apart and in the darkness of doubts and fears.

Then Liszt cites an unnamed witty woman, who exclaims in regard to the dancers performing the mazurka: "They often play a comedy to avoid a tragedy!" He goes on:

That which has never been spoken is yet often surmised

For a historical survey, social analysis, and pictures of the mazurka in action, see Maja Trochimcyzk, "Mazur (Mazurka)" online at http://www2/fiu.edu/ kneskij/mazurka (seen 14 November 2010).

89 Idelsohn, Jewish Music, 191.

90 Liszt, Life of Chopin, Broadhouse trans., 66. 
and understood. Vague generalities are often made use of to quicken interrogation, while hiding its drift, and evasive replies are closely listened to, like the ringing of a coin, as a test of quality. The suitor is often pleading his cause when he seems to be pleading for others, and the most graceful flattery is at times the veil which disguises exactions. ${ }^{91}$

To be sure, Alfred and Lucie were not courting or meeting for the first time; they had been married for five years, had two children, and found themselves in a state of shock and confusion by what had occurred when the arrest happened. But in this first major separation, ${ }^{92}$ they had to find a way to communicate in letters across layers of obscurity, ${ }^{93}$ knowing full well that everything they said to one another would be scrutinized by hostile censors, and thus they had to assume maskshow many, we shall be showing throughout this book, but not always masks of their own making - and then discovered that their own voices, intentions, and realities could not be seen or heard clearly by the other or by themselves. ${ }^{94}$ They would ask each other questions and knew they could not answer directly for several reasons: it was too painful to speak the words, and they feared of alarming the other; it was forbidden to transmit such information under the conditions of their right to send letters at all; it was beyond their individual capacities to describe or even

91 Liszt, Life of Chopin, Broadhouse trans., 66-67.

92 Earlier separations, as we shall see in later letters that they write to one another, were part of the normal routine for army wives and their husbands, a matter of days or weeks on maneuvers; this long separation during the affair tested their love and loyalty to an extreme not imagined in romantic novels.

93 The figure of the parokhet, the curtain drawn across the Holy of Holies, the Ark of the Covenant, represents in kabbalistic thought a separation between the visible and the invisible, the literal words on the page of a text, and the interpretations that make the invisible visible; see Ouaknin, Le livre brûlé, 284. For Alfred and Lucy, however, as they stand on either side of a veil of metaphysical and geographical distance, of censorious regulations forbidding the communication of vital kinds of information, of anti-Semitic hatred that they know will punish any references thought to be treasonous and part of an international Jewish conspiracy, of anxiety about each other's abilities to write and read between the lines, and of fears that what they say will inadvertently offend the other and trigger uncontrollable mental disturbances. At the same time, the veil of ambiguity and hinting also creates a mystical covering or canopy under which they hope to find or must create a city of refuge.

94 Dreyfus only rarely uses the word "mask" himself, but when he does, it opens up the vision of the dreadful nightmare and phantasmagoria playing all around him during the affair; cp. His letter of 3 October 1896 (Ecris-moi souvent, écris moi longuement, 322). 
imagine the full extent of their ordeals. ${ }^{95}$ For these reasons, without becoming a lighthearted farce or a grotesque comedy, the irony of their crisscrossing epistles and mutually supportive language created texts that could not really sustain the generic capacity of the language they thought they were sharing.

For example, in no way, can one say that either Alfred or Lucie were lying in what they wrote to one another. They are quite frank at times about how difficult it is to keep news from the other, and so while they intuit that each has more to say about their suffering day and night, neither can really guess the extent of what is happening to the other, Lucie especially in regard to the increasing isolation and physical tortures Alfred is subjected to and Alfred in regard to the efforts Lucie is making on his behalf to win a retrial and eventual rehabilitation of the family name, and the mounting campaign throughout France and the rest of the world to effect these ends. Thus, we see a hint at how to describe these factors in what Liszt writes concerning Chopin's mazurkas:

But the inimitable skill with which they are constantly able to interchange the garbs of truth and fiction (like touchstones, most certain when least suspected, the one always hidden under the cloak of the other) and the force which expends a great amount of intellect on the least important occasions (just as Gil Blas used up as much intelligence in finding the means of subsistence for one day as the King of Spain did to govern his whole dominions), at least make upon us an impression as painful as that produced by the jugglers of India and their exhibitions of wonderful skill, where sharp and deadly weapons fly glittering in the air, which the smallest error or the least lack of perfect mastery would convert into bright and swift messengers of instant death! Such skill is fraught with concealed terror, anxiety and anguish. From a complication of circumstances danger may lurk behind the essence of a question is to open and to leave open possibilities), and then "La chose demandée doit rester en suspens. . . mise en suspens de façon que le çontre' équilibre le 'pour"' (The thing asked must remain in suspense ... put into suspense in such a way that the 'contra' balances the 'pro') in $L e$ livre brûlé, 139. 
slightest inadvertence, in the smallest imprudence, in possible accidents, while on the other hand powerful help may be suddenly rendered by the most obscure and forgotten individual. ${ }^{96}$

Recognizing that not every single detail in this complicated statement bears pertinence to the Dreyfus letters, nevertheless I argue that Liszt's words set up a remarkable paradigm for arranging our analysis of those epistles. To begin with, however, we have to separate the rather complicated apparatus of analogues and allusions. In the first sentence, the two parenthetical remarks can be put aside for a moment, allowing us to see an allegorical narration of the dancers in the mazurka dressed alternatively in the costumes of truth and fiction and weaving in and out of contact with each other.

Then we see that the wearing of these "garbs" in the Polish dance is compared to the use of a touchstone, one of the four Stones of Wisdom can be shown to be metonymically related to each other, any one of which can stand for any one, two, three, or all four of the others, as a means of evaluating (the touchstone), sharpening (the whetstone), holding together (the keystone), and drawing into stronger contiguity (the lodestone) the others. ${ }^{97}$ In each particular instance, the stone itself has little or no significance, but by its function becomes more powerful, influential, and essential to the operation of the whole phenomenon. ${ }^{98}$

Liszt, Life of Chopin, Broadhouse trans., 68-69.

97 In the second parenthetical comment, Liszt alludes to Le Sage's picaresque novel of the Adventures of Gil Blas. This literary allusion is followed by a sustained comparison of the mazurka dancers with Indian fakirs, emphasis placed as much on the showy, somewhat duplicitous quality of the performers and on the real dangers that obtain should there be any slip-up or loss of attention. Like all picaresque novels, Gil Blas is the somewhat cynical reflections of a man or woman who has made it through life, most of it "on the road," at all levels of society, secular and religious, in cities and towns, at courts and in slums, and revealing finally that it is wit alone and taking care of oneself that really matter.

98 Although Ferenc or Franz Liszt was at times a fairly rabid anti-Semite-much more so than Chopin - what he wrote about the mazurka can be taken as an interesting insight and approach to the Dreyfus letters. There is much we can learn from the Jew haters since in their very mental illness, they see and speak about things that nice, liberal, tolerant people do not like to talk about-or can perceive at all. See, for instance, Dan Damon, "Chasms of Perdition: How Ferenc Liszt tried to tame the divine essence of the Romani soul," Central European Review 3: 13 (2 April 2001) online as http://www/ce-review.org./01/13/damon13 (seen 14 November 2010). Considering the book on The Gypsy in Music, written under the influence of Wagnerian antiSemitism, Damon argues, "Whatever the explanation for his anti-Semitism Ferenc Liszt made cynical use of the musical talent of the Roma to belittle whatever Jews had achieved. Liszt sought 
Now back to the exchange of epistles between Lucie and Alfred. These letters, those that survive today-and we cannot be sure how many were lost, were never sent, did not arrive, or were destroyed by the prison censors-also constitute another kind of textual phenomenon, one that recalls, however distantly, the multiple layers and polyphonic voices of the Talmud. In the history of letter writing in the seventeenth and eighteenth centuries, a whole genre of fiction based on the exchange of epistles developed. These fictional letters make clear some of the more specific aspects of the Dreyfus Affair as a whole and the exchange of letters between Alfred and Lucie Dreyfus in particular. Although there were already telegrams and a few telephones available at the end of the nineteenth century, for the most part people still communicated by handwritten letters. In Marcel Proust's A la recherche du temps perdu, it is possible to see the progressive development of communication from handwritten notes, telegrams, and pneumatic letters to the use of telephones. Official documents were also beginning to appear in typewritten form.

Handwritten epistles have to be read as emerging from the midst of existential experiences, speaking privately to the person or persons they are addressed to in terms of ongoing events and urgent or contingent actions. Unlike the communications available to us a hundred years later, wherein electronic and digital information can be exchanged instantaneously, written letters require often rare and expensive physical equipment-sheets of paper, a supply of pens, sufficient ink, sturdy envelopes, postage stamps, and a delivery service of some sort-but above all, time: time to think about what to say, time to inscribe the message and usually a copy or a résumé for one's records, and time to send the letter across long distances by ship, train, automobile, or horse-driven carriage and eventually on foot by a postman.

In regard to those epistles sent between Captain and Madam Dreyfus, it is necessary to point out again that the time to think about what to write was, mildly put, constrained, stressed, and difficult because of

\footnotetext{
to prove that merely being persecuted and stateless was not enough to excuse the Jews for their material success and ambition. Liszt's thesis was: the gypsies glorified God through the creation of natural beauty in the form of music; the Jews could only manage the worldly creations of money and crafted goods." In other words: "Jews were too clever for their own good." Finally, says Damon, "Liszt's adoration was of little benefit to the Roma, just as his bigotry failed to bury the achievements of Jewish musicians." Unfortunately, the kind of bile spewed forth by such admirable musicians as Liszt and Chopin helped pave the road to the crematoria and other killing fields of the Nazi empire.
} 
the conditions of Alfred's imprisonment: in particular his limited space; his confined quarters; the unpleasant, uncomfortable, and feverish heat; as well as the need to make his wishes for paper, pen, ink, and so forth known through the agency of prison guards who were meant to humiliate him and treat him as virtually a nonperson. It was consequently not only a matter of finding a time, a place, and a means for writing but of composing his mind, and that, most significantly, was something that was both the consequence of penning these letters to Lucie and the means by which such temporary "moral" equilibrium was achieved. Once he had found and made use of the time, the place, and the implements for composing his epistle, the situation was again out of his control: the letters he wrote, like those he received, were subject to strict censorship and might not be posted to Paris with any sense of urgency.

Similarly, Lucie Dreyfus also was constrained in what she could write by the knowledge that her messages would be scrutinized and subject to censorship, delay, or nondelivery. Yet her fortitude and forethought in inscribing letters were able to do several absolutely essential things: (1) not least, to meet the strict requirements of the regulations imposed by military and political officials, of which she was acutely aware-Lucie only slipped up on a few occasions, and those few were only because not even she could have imagined the cruelty operating against her and Alfred; (2) closest to the surface of what was being communicated, to use her cunning and intuition in composing letters that would provide some comfort to the prisoner, serve to forestall his depressive thoughts of suicide, engage him in a domestic relationship ${ }^{99}$ neither of them could be sure would ever be returned to anything like normalcy, if at all, again, and providing subtle hints of a project to have his case reheard and the judicial error that he, she, and other close family members or friends always presumed had been made corrected. Perhaps there was also a third

99 Burns puts together from mostly unedited materials in the archives a typical routine for the young married couple raising two children in the days before Alfred's arrest when their whole world was turned topsy-turvy: "Rarely staying in his office later than 6:00 p.m., [Alfred] rejoined Lucie for a quiet dinner followed by an evening at the symphony or a rubber of bridge with the Hadamards and family members visiting from the provinces. Most of the time, however, the couple spent alone, taking short promenades through their quartier and returning to read by the fire. They were building a considerable library in the new apartment, with titles that reflected their varied interests - from six-volume sets of Napoleonic campaigns, cavalry tactics, and military fortifications to histories by Fustel [de Coulanges] and Ernest Lavisse. Balzac novels, Shakespeare plays (translated into French), and a broad range of literary magazines and Parisian periodicals" (Burns, Dreyfus: A Family Affair, 98). 
subtle function in her letters to Alfred. Thus, more so than in his own desperate missives back to her, she reinforced his virtually never-mentioned Jewishness, directing in a very nuanced manner the direction of their private, intimate exchange of emotional signals, which lasted over a year or more, towards a sense of traditional, kabbalistic notions of tikkun ha'olam-restoration of primal order, repair of a fragmented existential reality, and revelation of a moral purpose and meaning in life..$^{100}$

The exchange of letters between husband and wife was anything but an orderly or regular one, therefore, since there was no real natural or logical flow of question and answer, remark and reply, while letters from Paris could have words, sentences, paragraphs, or even the entire content between the salutation and the farewell blacked out by prison authorities. When Alfred remarked in one letter, for instance, on the comfort deriving from the very fact of holding in his hand a piece of paper Lucie had held and seeing her thoughts and feelings written in her own loving hand, the authorities decided to have her epistles typed out by some minor functionary and on neutral, prison paper, thus depriving the husband of the least physical contact with his wife. How hurtful this administrative procedure was to Alfred and Lucie may be seen in her letter of 20 February, 1896, in which she expresses her relief that a letter has arrived from him in his own handwriting rather than in the impersonal lettering of a prison official:

C'est toujours une grande satisfaction pour moi que de voir ton écriture, il me semble que je tiens aussi une parcelle de toi; une copie supprime tout le caractère intime de la lettre et vous [. . . l'impression peut seul vous donner le travail machinal et tout personnel qui accompagne la pensée. ${ }^{101}$

It is always a great satisfaction for me to see your handwriting. It seems that I am holding on to a part of yourself. A copy suppresses all the intimate character of the letter and [gives] you [in the impersonal sense] the impression that only a mechanical piece of work gives and

100 Lucie had a more sustained and formidable knowledge of Judaism than Alfred, as we shall discuss in later volumes in which we consider Dreyfus in love and as a Jew.

101 Ecris-moi souvent, écris moi longuement, 350. 
[thus leaves out] everything personal that accompanies the thought.

Despite the awkwardness and fragmented nature of these remarks, we can see what she is trying to say. She recognizes the difference between a personal script, which can embody a writer's personality and circumstances, and a mere mechanical reproduction of the words. It is not only that the "impression" is different in each case but that the significant meaning is also different.

She then continues her little essay on the importance of handwritten epistles as a facet in their special, almost metaphysical relationship, generated under pressure in the letters they send to one another, a theme to be developed later in this chapter. For the letter, in the tradition of Jewish reading technology, has more than just a body of information that is communicated by the meanings of the words; the text and the words have a volume, a substantiality to them, in the way they fill the page they are written on, the size, the shape, the pressures of the hand on the paper, and the inner dimensions of language itself.

Même quand je te lis selon que ton écriture est plus ou moins ferme, je me forge toutes sortes de chimères, je te vois tantôt fatigue, tantôt énervé, ou courageux, ou déprimé. ${ }^{102}$

Even when I read according to whether your script is more or less firm, I create all sorts of phantoms. I see you sometimes fatigued, sometimes enervated, or courageous, or depressed.

Such a passage in her letters, when we read it after the passage of more than a century, resonates with historical ironies, not least of which is the connection to the nature of the crime committed against Alfred and his family through forged, suppressed, and pretended documents. But in this instant of her writing, Lucie is indicating the way she can interpret letters by extraverbal qualities in the physical object itself, and as we shall see later in this chapter, her own uncharacteristically formal tone points toward secondary levels of signification in her 
remarks-her own signal to Alfred that she understands more about his condition than she knows he is allowed to speak under the eyes of the censors and, furthermore, that she expects him to interpret her letters at deeper levels than she feels permitted to write, partly because of those same censorious eyes scrutinizing everything she sends to him and holding back or destroying anything that would bring him real comfort from knowledge of how far the Dreyfusard cause is progressing. Thus, still further in this same letter, with its misdating and its elided parts of sentences,

C'est cette impression qui me manque lorsque la lettre est copiée par une écriture indifférente et ce m'est l'une des choses les plus pénibles parmi tous les chagrins secondaires que j'ai eu à subir. ${ }^{103}$

It is this impression which is lacking when your letter is copied into an indifferent script and it is to me one of the most painful things among all the secondary chagrins to which I am forced to submit.

It should not be overlooked that "impression" is one of those words in the lexicon of late nineteenth-century Europe laden with aesthetic and intellectual weight, partly from the revolutionary changes in all the arts in regard to seeing, hearing, and shaping space and also in the views of the mind that give a new spin on the older mode of associationist psychology stemming from Descartes and Locke, there now emerging as a whole new concept of depth psychology, wherein the mind is not strictly under the supervision of the will, let alone the rational faculties (the superego), and deep memories, inexpressible passions, and anxieties (the id) act to create a consciousness (the ego) that is at best a phantasmagoric parody of the mind.

As in epistolary novels since the seventeenth and eighteenth centuries, such as Samuel Richardson's Clarissa, the recipient of letters could never be sure that what he or she held in their hands was an actual response to one of their own, and that answers were being given to their own questions and in the context of certain confessions or statements 
of fact, or even an actual message and not a major alteration or a total forgery. The entire case against the captain in the Dreyfus Affair itself can be seen as a series of manipulated documents, forgeries, out-ofsequence fabrications, and misconstrued or misapplied contexts.

Thus, the first body of evidence about Alfred Dreyfus the man, as opposed to the cipher used by others in an ideological battle that more or less obscures the real reasons for his being framed as a traitor, in his own words, comes in the five hundred or so letters that he and his wife Lucie wrote to one another. There are a few letters from his children and other members of his family, such as Mathieu, or friends, such as Joseph Reinach. These letters, while written under difficult circumstances for all concerned, (none, however, so much as Alfred's), were also composed with a consciousness that military and colonial censors would be scrutinizing every word for indications of Dreyfus's connections with the German government, suspicious markers of anti-government feeling or even conspiratorial machinations, and other evidence of alien thoughts and actions, not least of which would have been expressions of Jewish loyalty and beliefs, which in the heated anti-Semitic atmosphere of the times would have been tantamount to treason.

Nevertheless, Alfred and Lucie, in these letters over five years, managed to communicate deep feelings of mutual support and concern for each other and the children. Although Lucie could not let Alfred know about any of the efforts to gain a revision of the decision of the court-martial or reveal the extent of the support being built up amongst intellectuals, she could and did make him aware that he was not alone and that he should have hope. Alfred, on his part, in the way he repeated words and phrases from Lucie's letters, reiterated his own assertions of faith in the ultimate justice in the army and in France and of his affection for his wife and family, and - this is important-in what he did not write at all, in the choice of words he used, did more than communicate his private love for Lucie and the children and his profound faith in reason and in France, he also created a relationship that was, as we may see in many of the novels of the period, a new kind of very introspective domestic bond with Lucie, a very strong love based on trust and friendship without any of the traditional signs of masculine superiority or domination. These letters have been edited, selected, and printed several times in the past hundred years, sometimes to win support for Dreyfus in his call for a revision of the guilty verdict, sometimes to seek his rehabilitation as an honourable 
officer, and sometimes to provide a much fuller psychological or "intimate portrait" of the man and his wife.

The book called Five Years of My Life, published soon after his arrival back in France in 1898, contains a selection of those letters mostly between husband and wife, along with some introductory material and other things, such as sketches and photographs. Unlike the unedited, raw letters themselves, the book was designed, in all senses of the word, certainly with political intentions in order to garner support and sympathy for the cause of regaining the honour of his family name and his status in the army and yet as a means of creating a positive historical portrait of himself and thus hiding his weaknesses at the time of his arrest and during his long ordeal in prison and other aspects of his personality evident in the letters that he did not want made public. His weakness and feebleness were very real, and Alfred and Lucie both feared throughout the affair that he would not be able to make it through with his sanity intact. His hypersensitivity led him earlier in his life to assume a pose of aloofness, which was often taken as snobbery; he would not chat with his fellow young officers or drink with them, or even go riding with them. He was a shy, introspective and sometimes annoyingly withdrawn personality, preferring to spend time in the evenings with Lucie and the children, holidaying with her or his families, and studying. ${ }^{104}$

In addition, the very selecting and annotating of his letters, like the original act of writing them from his cell, provided Dreyfus with a means of trying to keep his mind focused and active in the endeavour he had undertaken to maintain his sanity and to avoid falling into despair, and committing suicide. Unlike the unedited letters, which demonstrate in their rhythmic repetition of key phrases and their private code of mutual affection the inwardness of Dreyfus's experiences, the edited collection does not emphasize this aspect of his circumstances. It misses out on the way he and Lucie helped each other create a special private Jewish space for their love. ${ }^{105}$ The edited collection is presented after Alfred's return to France, his release from prison, and is part of the campaign he undertook, along

104 A number of extravagant lies were concocted at the time of his arrest and publicized in the popular, anti-Semitic press that he had been a womanizer and a gambler. Nothing could be further from the truth.

105 As Andrew Marvell told his reluctant lover, “The grave's a fine and private place/ But none do there embrace." 
with his brother Mathieu and other friends and allies, to vindicate his name and punish the real culprits in the affair. The book presumes his own knowledge of how many supporters he has and how strong his case really is and therefore cannot be taken as a true context in which the painfulness of self-creation and self-discovery by Lucie and Alfred came about.

Dreyfus also kept a journal and added to it when he came back from Devil's Island. As he found out what had been done on his behalf, both by his family and by many strangers, he sought to understand the dynamics of the affair and to discover the truth of what had happened, who was really at fault, and who deserved punishment for this intricate and complex conspiracy to frame him and to protect the culprits who forged documents, perjured themselves in various trials, instigated the antiSemitic riots, carried out assassinations, attempted murders, and put France into great danger from foreign enemies. While Mathieu Dreyfus had quickly transformed himself from an Alsatian manufacturer into a clever activist and legal agent on behalf of his brother, and dealt with politicians, social leaders, and cultural celebrities, Alfred-very much weakened in body and mind by his ordeal—nevertheless trained himself to join in the investigations into his case. He too became able to speak to the intellectual elite of France as an equal. His journals record his transformation from artillery officer well versed in technological knowledge to political scientist and, in a sense, moral philosopher.

The third body of evidence is much more difficult to deal with. It consists of his prison notebooks, the cahiers, kept while on Devil's Island. There were, it seems, at least thirty-five of these workbooks in all, ${ }^{106}$ the first twenty of which were destroyed by their author, leaving fourteen, deposited in the Bibliothèque Nationale de France and now edited by Pierrette Turlais in a mixed facsimile-transcribed version. There may have been drafts of Alfred's letters in the first, now missing, notebooks. In addition to the mathematical formulae and drawings also probably evident in the lost volumes, the remaining cahiers contain in addition reading notes and exercises in translation of English.

106 Alfred Dreyfus, Les Cahiers de l’Ile du Diable, ed. Pierrette Turlais (Paris: Éditions Artulis, 2009$), 44$. See also Thomas Wieder, "Les exercices d'écriture du bagnard Alfred Dreyfus," Le Monde des Livres (17 Décembre 2009) online at http://www/lemonde.fr/web/imprimer_element/0,40-0@2-3260, 50-128 (seen 22 March 2010). 


\section{Shekhina, Lucidity, and Illumination}

If, therefore, he [Balzac] wrote chiefly to women it was not only, as he remarked scoffingly to Théophile Gautier, because "cela forme le style," but from a profound and perhaps partly subconscious desire to find the woman who would understand him.

-Stefan Zweig ${ }^{107}$

The divine woman is an "optical apparatus" that refracts the light and renders the veiled image visible, like the rainbow that is manifest in the coverings of the cloud.

—Elliot R. Wolfson ${ }^{108}$

Lucie Hadamard, young as she was during the whole Affair, ${ }^{109}$ became the one person who found out who Alfred Dreyfus really was - that is, the real person inside the awkward, shy, and public cipher. Thus, she served as the virtual Jewish muse who inspired him with courage to explore his inner self and to stay alive as a thinking man. The woman of twenty-four at the time of his arrest discovered how, in the very act of understanding him as no one else did, neither at the time of the affair nor virtually since then, she could transform his love of herself, family, and nation into something more than romantic fantasy, sentimental piety, and patriotic fanaticism. Michelle Perrot correctly describes her character in this situation:

Elle connaît le pouvoir des mots, même différés. Elle est consciente de la situation épouvantable que vit son mari.

107 Stefan Zweig, Balzac, trans. William and Dorothy Rose, 2nd ed. (London: Cassell \& Co., 1948 [1947]), 113. This is the last book that Zweig wrote and posthumously edited from fragmentary manuscript pages by Richard Friedenthal in London in 1945.

108 Elliot R. Wolfson, Through a Speculum that Shines: Vision and Imagination in Medieval Jewish Mysticism (Princeton, NJ: Princeton University Press, 1994), 274. Wolfson, who is paraphrasing Zohar 1:18a, b, goes on to say most shockingly, "Here we come again upon the mechanics of vision, and the implied iconicity of the divine: what has form is invisible and what is visible has no form" (275).

109 When they were married on 21 April, 1890, by the Chief Rabbi, Zadok Kahn, she was twenty years old and Alfred was thirty. Cf. Michelle Perrot, "Lucie et Alfred: Avant-propos," Alfred and Lucie Dreyfus, "Ecris-moi souvent, écris moi longuement souvent, écris-moi longuement ..." Correspondeance de lîle du Diable (1894-1899), ed. Vincent Duclert (Paris: Mille et Une Nuits, 2005), 9. 
Elle sait la nervosité de cet être hypersensible, pénétré de l'importance du cerveau, organe phare du discours médical, qui lui confesse 'un état d'éréthisme cérébral et nerveux [.. . ] terrible" (4 Novembre 1897). ${ }^{110}$

She knew the power of words, even [when] differed. She was conscious of the horrible situation in which her husband lived. She knew the nervousness of this overly-excitable being, who perceived the importance of the brain, the guiding organ of medical discourse, who confesses to her that he is in "a state of extreme cerebral irritability and [... terrible nervousness" (4 November 1897).

How she grasped the psychological and psychiatric symptoms Dreyfus describes in his letters, which are only partly transferred from his journals written at the same time, indicates at least four factors in her personality which surprise and shock anyone familiar with the knowledge and understanding supposedly characteristic of middle-class women of the period. First, she must have had a particularly acute intuition, very much in harmony with her husband's mentality, and thus been able to extrapolate details and implications from his cris du coeur and attempts to articulate and hence to control his sense of enervation, the normal term for such irritability and unsteadiness. Second, well-read and intelligent, she was able to draw on her own formal education and memories of conversations at home with her parents, siblings, their spouses, and their intellectual friends, and coordinate it with recollected domestic discussions with Alfred during their first four years of marriage. Third, Lucie herself was going through a moral crisis-moral in the sense we have already shown as usual in the period as the term for what we would classify as both psychological and ethical-and thus could read out of her own painful experiences an analogy to Alfred's condition. Fourth, as the daughter of a religious Jewish household who imbibed the commonplaces and ritual patterns of rabbinical thought and who was educated in the essentials of liturgy, prayer, and argumentation accessible to intelligent women at the time, Lucie could fit the diagnosis she was intuiting of Alfred's mental illness with her knowledge of treatments implicit

110 Michelle Perrot, "Lucie et Alfred: Avant-propos," 15. 
in many Hebrew proverbs, exemplary tales, and juridical rulings. While neither she herself nor her family were as au fait with intellectual developments in Parisian society as were Proust's mother and grandmother, the latter's formation in both French and Jewish cultures was probably not different in kind from that of Lucie Hadamard. ${ }^{111}$ Each of these four qualities of her character will be discussed as we read our way through some of the hundreds of letters exchanged between 1894 and 1898.

Recent historians of the affair, like Michelle Perrot and Vincent Duclert, describe Lucie as the embodiment of truth, justice, and wisdom who was able to keep her husband sane and alive during the five-year ordeal of his imprisonment. More than that, she was to Alfred the incarnation or the imaging forth of Emet, Daat, Hochma, and Shechina, powerful, dynamic concepts in Kabbalah. We should be reminded that Kabbalah was becoming fashionable again amongst intellectuals at the turn of the century, and that unlike Eastern forms of mysticism to which it is often compared, it is, in Mel Alexenberg's words, "a down-to-earth mysticism to encounter everyday life." ${ }^{112}$ More than that, I would argue, it is a brilliant exercise in mythical and mathematical thinking that coordinates rabbinical tradition with the most up-to-date science in its milieu, and hence the sort of thought-game that would have interested Alfred Dreyfus had he known about it. That he didn't know in any explicit way is obvious, but just as obvious, as I hope this book shows, was his implicit grasp of its essential principles. ${ }^{113}$

In Ecris-moi souvent, écris moi longuement souvent, the editors divide up the letters according to the historical periods of Alfred's incarceration, where he was located and how intense were the isolation and other forms of torture applied. The examination that follows, however, does not seek to read out of the epistles any historical narrative of their relationship or any coordination to events taking place in Paris at the same time. As we have said, the letters form a continuous process of recreating their mutual love and loyalty in terms virtually unknown elsewhere in nineteenth-century French or European literature, and they may be

111 Evelyne Bloch-Dano, Madame Proust (Paris: Grasset, 2004).

112 Menachem Wecker, "Interview: Mel Alexenberg" Iconia (31 January, 2007) online at http://iconia. canonist.com/2007/01/31/interview-mel-alexenberg (seen 20 December, 2010).

113 How such an implicit absorption or imitation of cultural factors can occur in a family group or small community is hinted at in Gabriel Tarde, L'opinion et la foule (Paris: PUF, 1989; orig. 1901), 66-67, insofar as he begins to use terms and concepts at the heart of contemporary psychohistory, such as group fantasy and collective unconscious. 
seen as engaged in a kind of plural analysis. ${ }^{114}$ It will be seen therefore that in the initial period of their communications, while Alfred was transferred to different military prisons in France and before the regimen of constant censorship, rewriting of letters, and delays or blockage of delivery was in place, husband and wife could probe each other's responses and teach themselves to read the subtexts in their epistles.

In these letters of late 1894 and early 1895, almost everything that will be found later is set out in a preliminary format. The first extant letter is the one of Tuesday, 4 December, 1894, that Alfred writes while still in the Cherche-Midi prison in Paris waiting for his court-martial. He says he finally has a moment in which to write to his dear Lucie.

Je ne peux pas te décrire tout ce que j'ai souffert, il n'y a pas au monde de termes assez saisissants pour cela. ${ }^{115}$

I cannot describe to you all that I have suffered; there are not words strong enough for that.

Although these statements are clichés common to all intimate letters and especially to lovers forced to be apart, they provide the establishment of a programme to overcome separation and the limits of normal language. Alfred will have to learn how to describe his sufferings-that is, to find a lexicon of words, phrases, and allusions that communicate his condition and his feelings - while Lucie will have to learn how to confirm his ordeal by expressing her understanding and her sympathetic suffering. Three aspects to the problem are (1) hitherto, the couple have not had to write letters to one another, except the normal notes back and forth when, during their courtship, Alfred was on manoeuvres, and so now both must learn how to translate their ordinary oral communications by fragmentary speech, gestures, and acts of endearment to one another into coherent written discourse; (2) as a respectable $\mathrm{Pa}$ -

114 The term is taken from the teachings of William Théaux, a French psychoanalyst who studied with Jacques Lacan in the 1960s and who developed in Paris and Lyons a form of relationship between analyst and analysands based on the group of patients making a contract with and monitoring the doctor in such a way as to interfere with the usual problems of transference: countertransference since it was the collective that had the power not the authoritative analyst. This mutuality of the Dreyfus couple also suggests other forms of lay analysis conducted by groups of individuals who alternatively play the roles of analyst and analysand.

115 Ecris-moi souvent, écris moi longuement, 70. 
risian middle-class couple they suddenly have to override the norms and conventions of that respectability, with its built-in dominance by the husband, the reticence of the wife, and the coyness of both to articulate intimate desires, longings, and memories; and (3) as a mostly assimilated Jewish man and woman writing to each other in French, they have to devise some strategies for expressing deeper, more emotionally-laden and culturally-particular feelings and memories associated with their Jewishness.

Now a few lines later in the same letter, Alfred says,

Mais j'espère en Dieu en la justice, la vérité finira bien par se faire jour. Ma conscience est calme et tranquille, elle ne me reproche rien. ${ }^{116}$

But I hope for Justice in God, that the Truth will finally see the dawn of day. My conscience is calm and tranquil, and reproaches me in nothing.

For virtually the first and only time in all his letters, Alfred here explicitly expresses his belief in God; later he will allow Lucie to make those references, even obliquely, while he speaks, as he does in the next part of the sentence, of his secular faith in justice and truth. He is firm in his beliefs and is sure that ultimately the truth will out against all the calumnies brought against him. Yet by the next pasage, he is starting to describe a mental state that will trouble him throughout his entire five years of incarceration, one that Lucie will recognize as having been evident in nuce from the beginning of their relationship:

J'ai toujours fait mon devoir, jamais je n'ai fléchi la tête. J'ai été accablé, atterré dans ma prison sombre, en tête-à-tête avec mon cerveau, j'ai eu des moments de folie farouche, j'ai même divagué, mais ma conscience veillait. ${ }^{117}$

I have always done my duty, never have I bowed my head. I have been overwhelmed, thrown to the earth in 
my dark prison, in a conversation with my own brain, I have had moments of wild madness, I have been incoherent, but my conscience watched over me.

In what seems like a contradiction, he claims that he has never bowed down before adversity, like Mordechai in the book of Esther when asked to bow before the tyrant Haman, or like any Jews under pressure to bow to the idols of worldly power and corruption. The brute force brought against him has been overpowering, and he has been brought low, as he has, by implication in the metaphoric use of the same words that describe how he is actually-and will be even worse off as the time goes on, having been subjected to cruel treatment and torture. Nevertheless, in this state of physical and psychological defeat, he has entered into a dialogue with himself, a tête à tête with his brain, his mind, his intellect, and his inner self. Note how each of these clauses seems to relate to the others less as a developmental order of intensifying understanding or engagement but more as a string of non sequiturs, as though all were simultaneous, part of the knot of confused sensations and thoughts that assail him. Yet despite this confusion, he comes back to his faith, now in the form of his conscience that is the nurse, guide, and guardian of his sanity-his rational self. It is the guardian angel, the guiding spirit, this image of God in himself that he knows will protect him, but at the same time, given the context of all the subsequent letters, this conscience is also something else: it is Lucie herself, as he repeats more and more often, whose picture is in his mind ${ }^{118}$ and whose constructed presence in his imagination keeps him healthy, alive, and sane-she is, in other words, his Shekhina, his Hochma, his embodiment of justice and truth. ${ }^{119}$

118 "Created in the image of divine reality, man is its realization in matter" (Benmozegh, Israel and Humanity, 155).

119 Wolfson shows that "Through the agency of the imagination one enters the 'álam al-mithăl' (mundus imaginalis), in Henry Corbin's telling phrase, which is not the imaginary world of subjective fantasy or psychotic hallucination, but is instead a realm where invisible realities become visible and corporeal entities are spiritualized. The world of the imaginal [sic] is an intermediary realm wherein the imaginative forms (or archetypal images) symbolize the intelligible in terms of the sensory. The primary function of the imagination is hermeneutical: rather than recalling past sense data or combining these data in some innovative and, technically speaking, unexperienced way, the imagination produces symbols of the spiritual entities that act as interpretive filtering screens through which these entities appear in human consciousness," (Through a Speculum that Shines, $61,62$.$] As we shall subsequently show, in Dreyfus' special epistolary relationship with his$ 
Then Alfred continues with his letter:

Elle [i.e., his rational inner self] me disait: "Haut la tête et regarde le monde en face! Fort de ta conscience, marche droite et relève-toi! C'est une épreuve épouvantable, mais il faut la subir." 120

She spoke to me: "Hold your head up high and look the world in the face! Fortified by your conscience, march forward and free yourself! It is a horrible ordeal, but you must submit to it."

Preparing himself for the ceremony of disgrace when his military insignia will be stripped away and his sword broken and when he will be marched before the troops as a mark of his humiliation, Dreyfus girds up his loins with courage, rehearsing too his dignified refusal to accede to the charges against him by signalling to Lucie what he will do in the courtyard: he will shout out repeatedly, "I am innocent!" and "Vive la France!"

In a postscript to this letter, the husband warns his wife of the fact that from now on, they will have no moments and no place of intimacy, and that all their private messages will need to be oblique and secretive:

Ecris-moi souvent, écris moi longuement à la prison: tes lettres passeront comme les miennes, par M. le Commissaire du Gouvernement. ${ }^{121}$

Write to me in prison; your letters will pass like my own through the Government Superintendent

A more significant directive to Lucie than this reminder that from now on everything they say or write or do will be under strict censorship is

wife, neither the Sufi ideas nor the Jungian concept of archetype plays a part. However, Wolfson's most secret and shocking insights from medieval Jewish Kabbalah do touch on one of the most hidden of the torments Alfred experienced, the long separation from sexual relations with Lucie and the inability of his finding any relief because of his round-the-clock surveillance and because at times he was shackled to his bed throughout the night.

120 Ecris-moi souvent, écris moi longuement, 70.

121 Ecris-moi souvent, écris moi longuement, 71. 
given in Alfred's letter of 10 December, wherein he tells her,

Nous aurons besoin tous deux de nous soigner réciproquement pour oublier cette terrible éprouve, la plus terrible que les forces humaines puissant supporter. ${ }^{122}$

We will both have need to take care of one another in order to forget this terrible ordeal, the most awful the human powers can sustain.

Here is a recognition of reciprocity in their ordeal and of the need for mutual endurance, and a dynamic and interactive process of communicating to create a place out of real space and a time out of real time where they can not only share their love and loyalty but also generate the power necessary to transform the status quo, a process that Lucie must undertake on her own, against all expectations of a young married woman, and with Alfred providing his own support and directions for her efforts. In the event, of course, he does not know and therefore cannot appreciate all that she is doing, both on her own and in collaboration with his brother, Mathieu, and other members of the family, along with a growing number of Dreyfusards who rally to the cause over the years.

Meanwhile, Lucie, through intuition and intelligent guesswork, tries to translate the clues and hints provided by her husband's letters at once to feed him back the strength he needs from his own words, by her confirmation in repetition of what he says or implies, and to avoid raising false expectations or generating suspicions in the censorious eyes always monitoring her letters.

We can see this happening in the first of her letters printed in Ecrismoi souvent, écris moi longuement, from 23 December, 1894. She begins with exclamations of sympathy and pathos:

Mon pauvre, pauvre Fred chéri, Quel malheur, qu'elle torture, quelle ignominie. Nous en sommes tous terrifies, anéantis. Je sais comme tu es courageux, je t'admire. Tu es un malheureux martyr. ${ }^{123}$ 
My poor, poor Fred darling,

What unhappiness, what torture, what ignominy. We are all frightened, crushed. I know that you are courageous, and I admire you. You are an unhappy martyr.

Not Lucie alone but both her whole family and his are dumbfounded by what has happened, and no one believes the charges against him are possible. She has probably not received his letters yet, or if she has, they have not registered yet in their full import, so she speaks here on behalf of the whole extended family (the mishpucha) to reassure him that he is not forgotten or rejected. She also must begin to urge on him the importance of not giving in to despair, of not taking the soldier's way out - suicide-as hoped for by his brother officers in their initial search for confirmation of guilt, to avoid the tedious duties of preparing a case against him. She remains loyal. Unlike so many wives and families in similar circumstances, real and fictional, Lucie does not desert him in his time of need, having complete and utter faith in his innocence, nor will either of their families, no matter what public ridicule is poured over them and what social inconveniences are put in their way, such as servants leaving their employ, having to move into one large household together, and pooling their wealth to employ the best lawyers and detectives to defend him and get to the bottom of the mystery. Thus, she reassures Alfred:

Notre vie, notre fortune à tous sera sacrifiée à la recherche du coupable; nous le trouverons, il le faut. Tu seras réhabilité. ${ }^{124}$

Our life, our fortune, all will be sacrificed in the search for the guilty party, we will find him, we must. You will be rehabilitated.

By her second letter of 23 December, written in the evening, she begins to play off his words. She echoes his cries of pain and anguish, his fears of going mad, and his asseverations of innocence, and speaks now with a different form of "we" than in the earlier letter, where it seemed 
primarily to stand for all the people in his and her family; now it represents more clearly the couple itself, husband and wife, who must see themselves as together in this ordeal, each one's pains and humiliations, loneliness and torture, to be shared and thus made bearable.

Tu sais si je t'aime, si je t'adore, mon bien cher mari; notre immense malheur, l'horrible infamie dont nous sommes l'objecte ne font que resserrer encore les liens de mon affection. ${ }^{125}$

You must know that I love you so much, that I adore you so much, my dearly beloved husband, our immense unhappiness, the horrible infamy of which we are the object can only strengthen the ties of my affection.

Then she echoes the famous words of Ruth in the Bible ${ }^{126}$ when she comes back with her mother-in-law Naomi to live with her as a dutiful daughter-in-law. For though a Moabite, the traditional enemy of the Israelites, she avers,

Où tu iras j'irai, où tu demeuras je demeurerai; ton peuple sera mon people, et ton Dieu sera mon Dieu; où tu mourras je mourrai, et j'y serai enterrée (I.16-17)

For whither thou goest, I shall go; whither thou lodgest I shall lodge. Thy people shall be my people, and thy God shall be my God; where thou diest, will I die, and there will I be buried.

This passage is a locus classicus of Jewish love and loyalty across all differences and distances.

Partout où tu iras, où l'on t'enverra, je te suivrai; à deux nous supporterons plus facilement l'expatriement, nous vivrons

125 Ecris-moi souvent, écris moi longuement, 81.

126 As well as of the Song of Songs: "Set me as a seal upon thine heart, as a seal upon thine arm: for love is strong as death ...." (8.6). 
l'un pour l'autre ... ; nous élèverons nos enfants, nous leur donnerons une âme bien trempée contre les vicissitudes de la vie. ${ }^{127}$

Wherever you will go, wherever they will send you, I will follow you, we two together will support the expatriation more easily, we will live for one another ...; we will raise our children, we will give them a soul well-tempered against the vicissitudes of life. ${ }^{128}$

Although her words may echo romantic novels and other exaggerated and postured literature, in this letter, Lucie pushes herself beyond the boundaries of bourgeois convention to assert the mutuality of their love, not only a passionate sensual amour between lovers but a domestic bond transcending sentimental pieties. Later, to be sure, it will become clear that a special law has been passed in the assembly to keep Alfred from being sent to New Caledonia, where wives could follow their husbands and even bring their children to be raised in the colony. He will be sent to Cayenne, to the small former leper colony island known as the Ile du Diable, and there kept in isolation and subjected to unprecedented indignities. At the moment, however, when Lucie still believes there is a chance to go into exile with her husband, she is prepared to leave her comfortable life, her family, and her Jewish community to be with Alfred. When Alfred eventually hears of this, he will argue against her plans. Even before he knows of the destination of his exile, he does not want his wife to separate herself from her family and take the children away from their cousins and grandparents, and the opportunities for education possible only in Paris; most of all, to accomplish his deep wish to be reunited with her, he needs Lucie to stay in France and lead the fight on his behalf against the wrongful charges brought against him and the judicial error committed in the court-martial.

In making himself dependent on his wife in this way, Alfred departs

127 Ecris-moi souvent, écris moi longuement, 81.

128 A friend from France thought the words as well as the sentiments of the loving husband and wife "old-fashioned." But this reversion to a somewhat archaic diction and attitude certainly is the heart of the matter, especially as the passage echoes biblical Hebrew. The lovers support one another because they otherwise would fall, as a house collapses in a storm, as a wounded person needs the aid of another to stand straight. Their souls are well-tempered, in the sense of a musical instrument that stays in tune despite changes in the atmosphere. 
from the normal continuities of domestic politics as understood in most of Europe at this time, which has men dominant and actors in the public sphere and women subordinate and at best active in the privacy of their homes or in small salon circles. Their love will be changed into one based on friendship, mutual trust, and negotiations of how to do and say things in public. Thus, in his letter of 24 December, 1894, ${ }^{129}$ Alfred writes to Lucie:

Oui, ma chérie, tu es sublime de courage et de dévouement; tu vaux mieux que moi. Je t'aimais déjà de tout mon coeur et de toute mon âme; aujourd'hui, je fais plus, je t'admire. Tu es certes une des plus nobles femmes qui soient sur terre. Mon admiration pour toi est telle que, si j'arrive à boire le calice jusqu'au bout, ce sera pour être digne de ton héroïsme. ${ }^{130}$

Yes, my beloved, you are sublime in your courage and your devotion, you are worth more than I am. I loved you already with all my heart and all my soul; today I do more, I admire you. You are indeed one of the most noble women ever on earth. My admiration for you is such that if I reach the end and must drain the chalice to the dregs, it will be in honor of your heroism.

Here we can see the husband worshipping his wife, a sublime and noble woman, praising her for her courage and heroism, so much so that he would be honoured if he were called upon to sacrifice himself, as Jesus did before his Crucifixion, but such an explicit Christian concept might be given a less offensive tone by alluding obliquely to a classical instance, the point in his imprisonment when Socrates chose to drink the hemlock. Implicit in this confession of his faith in Lucie (Pennina or Pr'ei Or, meaning the Face of Light, divine illumination, or enlightenment) is recognition in her of the qualities associated in Jewish tradition with heroic figures such as Esther, Judith, or Ruth, females hypostatized in

129 They do not take notice of the fact that it is Christmas Eve. The normal calendar, Christian or Jewish, disappears before the existential time of their suffering and love. Holidays are only mentioned in reference to the children, both when Lucie speaks of their excitement and Alfred of the need to purchase them toys.

130 Ecris-moi souvent, écris moi longuement, 84. 
kabbalistic tradition to the roles of Wisdom, Truth, and Shekhina, the shadow or presence of God in exile.

In response, not necessarily direct since letters were constantly delayed and crisscrossing each other, on 26 December, 1894, Lucie pens these words:

Pauvre cher Freddy, comme tu es courageux, quelles horribles tortures tu endures. Tu es bon, foncièrement bon, tu as toujours été pour moi le plus tendre, le plus attentionné des maris, tu m'as témoigné pendant ces quatre années de vie commune une affection, un dévouement dont je te sais reconnaissante et, mon pauvre trésor, ce qu'il y a de plus pénible c'est que tu n'es pas du tout au bout de tes souffrances. Je te demande un énorme sacrifice, celui de vivre pour moi, pour tes enfants, de lutter jusqu'à ta réhabilitation qui, j'en suis convaincue et nous le sommes tous, ne tardera pas à venir. ${ }^{131}$

Poor dear Freddy, how courageous you are, what horrible tortures you are enduring. You are good, thoroughly good, you have always been to me the most tender, the most attentive of husbands, you have vouchsafed to me over four years of our life together an affection, a devotion of which I am completely conscious and, my poor treasure, what is even more distressing is that you are not at the end of your sufferings. I ask of you an enormous sacrifice, that of living for me, for your children, of fighting on until your rehabilitation which, I am utterly convinced and so are all of us, will not be late in coming.

This mutual admiration society increases in intensity into a virtual cult of mutual worship, as when Alfred writes on 26 December, 1894:

Tu es sublime, mon adorée, et j'admire ton courage et ton héroïsme, Je t'aimais déjà; aujourd'hui, je me mets à deux genoux devant toi, car tu es une femme sublime. ${ }^{132}$ 
You are sublime, my adored one, and I admire your courage and your heroism. I loved you before already, but today I bend both my knees before you, for you are a sublime woman.

In one sense, the pattern of worship, adoration, and genuflection recalls the Marian worship popular in France during the second half of the nineteenth century, as seen in Emile Zola's Lourdes, the first novel in his trilogy, Les Trois Villes, ${ }^{133}$ which describes the ecstatic fervour displayed at the shrine. It would have been difficult for a person to live in Paris in those years and not be affected by the intensity of the Catholic cult, even if, like Alfred and Lucie, as assimilated Jews, he or she found the whole idea of such popular mysticism bizarre and repugnant. Although the pair may have known something of Jewish mysticism, with its kabbalistic rituals and formulae, it would also have been foreign to their sensibilities. However, in times of extreme stress and anxiety, the language and iconography overcome these cultural filters, and the terms and concepts come streaming into their letters as a way of expressing the inexpressible and imagining the unimaginable. At one point, breaking the conventions of bourgeois French patriarchy, not in the manner of Romantic poets or even earlier troubadors from Provence, Alfred exclaims: "Decidément, ma chère adorée, les femmes sont supérieures à nous; parmi elles, tu es des plus belles et des plus nobles figures que je connaisse"134 (Decidedly, my dearly adored, women are superior to us [men]; amongst them, you are the most beautiful and noble that I know). This hyperbolical language of love, is it sincere? Should we take it literally? In what sense is it metaphorical?

Without it, Alfred finds that he has no other way to tell Lucie about what he is going through: he can, he claims, resist the physical suffering- "elles glissent sur ma peau" (they slide off my skin). But what he

133 Emile Zola, Trois Villes, trans. as Lourdes, Rome, Paris by Ernest A. Vizatelly. It is especially in the crowd scenes of pilgrims processing up and around and then into the shrine of Our Lady of Lourdes-chapter after chapter of increasing ecstasy and bizarre behaviors-where Zola manifests the full power of the fanaticism in the pious Catholics of all ranks in society. This wild scene might also be compared to the religious excitement Zola describes in the second volume of the trilogy, Rome, where a papal ceremony nearly turns into a riot, and the Holy Father has to escape, though first trying to salvage the many coins that roll away.

134 Alfred to Lucie, 27 December, 1894: Ecris-moi souvent, écris moi longuement, 94. 
cannot face is "cette torture morale" (this moral torture). As we pointed out already, the term moral plays a key role in the formation of the experiential basis of the affair and the way those closest to its centre respond to it: it refers to ethical, emotional, psychological, and spiritual states of being in the individual and the various collectivities involved, not least the husband-wife unit of Alfred and Lucie, their immediate families, and the inner circle of early Dreyfusards. This moral torture is also "le drame le plus effroyable" (the most horrible drama), a calvaire (a calvary) or martyre (a martyrdom). In other words, something inflicted by one group on another person who is himself less an individual than a metonymic representative for the group he or she belongs to. It is a festival of hate, pain, and humiliation against the central figure, who remains in the heart of the panopticon, where all can see him, although only a few, like Lucie, feel along with him because they are part of him. ${ }^{135}$

Alfred writes to his wife on the twenty-sixth of December-note how many letters are written in one or two days, as though writing is the only way for both of them to endure the torment of their separation and the knowledge of the other's sufferings:

\begin{abstract}
Ah! ma chérie, si je ne t'avais, comme je quitterais la vie avec délices! Ton amour me retient, lui seul me permet de supporter la haine de tout un people. ${ }^{136}$
\end{abstract}

\begin{abstract}
Ah, my cherished one, if I did not have you, how I would quit this life with joy! Your love holds me back, the only thing that enables me to support the hatred of a whole people.
\end{abstract}

135 On what happens when the ritualized and licit Festival of Laughter and Blood gives way to the violent outbursts on the street of a new game called Pasquino, listen to Romain Rolland: "The more moral stringency paralyzed action and gagged speech, the bolder did action become and speech the more untrammeled during those few days. Everything that was secreted away in the lower depths of the soul, jealousy, secret hate, lewd curiosity, the malicious instincts inherent in the socials animal, would burst forth with all the vehemence and joy of revenge. Every man had the right to go into the streets, and, prudently masked, to nail to the pillory in full view of the public gaze, the object of his detestation, to lay before all and sundry all that he had found by a year of patient industry, his whole hoard of scandalous secrets gathered drop by drop" (Jean Christophe, vol. III, 305). In a sense, the Dreyfus Affair works in an analogous way, when France, afraid to speak the secret anxieties over modernization, projects its inner demons and empties the poison sack of its self-hatred on to the Jew and pretends it is all for reasons of state and the ideals of king, army, and church.

136 Ecris-moi souvent, écris moi longuement, 91. 
The enormity of the humiliation and shame he feels is registered as the hatred of the whole nation, all of France, every single person outside of his own family, especially Lucie, and every institution and principle he once believed in with the fervour of a devotee.

The second section of Ecris-moi souvent, écris moi longuement is devoted to letters written from 5 to 17 January, 1895, while Alfred was kept in the Santé Prison awaiting deportation to Devil's Island. Reassuring his wife on 5 January, 1894, that the degradation having been passed through and the impending exile being imminent, "Le moral tient" (his moral being remains strong and firm, his inner courage); he nevertheless "commence à être à bout de patience et de forces" (begins to feel his patience and his strength running out). ${ }^{137} \mathrm{He}$ also fears the moral collapse of his mind, the plunge into a mad and painful confusion of his nervous structure: "il me semblait que jétais le jouet d'une hallucination" (it seemed to me as though I were a plaything in an hallucination). ${ }^{138}$

Then on the evening of the same day, not finding any consolation, he cries out in near despair that all his ambitions, achievements, and honour, and his love and devotion to the fatherland are all "perdues par une machination qui procède bien plus du fantastique que du réel"139 (lost in a machination - what we have decided to call the contraption-that is driven more by the fantastic than the real). In the letters that follow, Alfred and Lucie repeat the basic terms and images of the letters from Cherche-Midi, even with the constant warning that " $M$. de Directuer de la prison . . . est obligé de lire toutes me lettres"140 (the Prison Warden is required to read all my letters). These writings, though, also advance the thoughts and feelings the husband and wife have about one another, something that shows them both learning, each in their own style, to operate within the straitened circumstances of distance and isolation, and the text thus confirms our earlier interpretations and also exposes the semantic zone allusion the Dreyfuses express, whether or not they are fully conscious of its implications.

Not all that they write indicates a realization of the need to maintain a secret code drawing on their shared Jewish background, but the

137 Ecris-moi souvent, écris moi longuement, 119.

138 Ecris-moi souvent, écris moi longuement, 120.

139 Ecris-moi souvent, écris moi longuement, 122.

140 Ecris-moi souvent, écris moi longuement, 131. 
evidence does begin to mount that to a certain degree, they are indeed aware of something different and deeper in their minds emerging in these letters. Thus, on 8 January, 1895, in the same letter in which Alfred mentions the censorship operative all the time on his lettersmeaning those he writes and those sent to him-he also says,

Tu me demandes aussi, ma chérie, ce que je fais du matin au soir, et du soir au matin. Je ne veux pas te communiquer mes tristes réflexions, ta douleur est déjà assez grande, et il est inutile de l'augmenter encoure. Ce que je t'ai dit plus haut suffit pour te faire comprendre ce que je désire en ce moment: l'exil en plein air avec toi, en attendant la réhabilitation, Quant au reste, je te le raconterai plus tard, quand nous serons réunis et heureux. ${ }^{141}$

You also ask me, my darling, what I do from sunrise to sunset and from sunset to sunrise. I do not want to tell you my sad reflections, your grief being already great enough, and it is useless to increase it further. What I told you above suffices for now to let you understand what I desire at this very moment: exile in the open air with you, waiting for the rehabilitation.

As for the rest, I will tell you everything much later, when we are reunited and happy.

On the surface, Alfred says he will not give her details of his daily routine and thus fill his letters with a diary of the experiences and feelings of each day. He rejects the use of the letter as a journal of events and a narrative of his shifting emotions. What he has written already-a few brief descriptions of the conditions under which he is imprisoned-are all he will say on this matter. More profoundly, the dismissal of her request to share through letters his every moment of suffering indicates that the letters will be directed to a different level of experience and use language for a purpose other than conveying information.

In a letter from la Santé Prison written on 9 January, 1895, Alfred speaks to Lucie in one of his most explicitly Jewish confessions. He be- 
gins by telling her that he has just received a batch of belated letters from her and the rest of the family. In these circumstances, he tells her, "Il faut nous incliner et suffrir en silence"142 (We must bow down and suffer in silence) - that is, accept the inevitable with resignation and make no cries of complaint or pain. Recalling the day of his degradation the previous Sabbath, he declares, "Cette journée de Samedi reste dans mon esprit gravée en lettres de feu"143 (This day of the Sabbath/Saturday remains engraven on my heart in letters of fire), an image drawn from biblical and rabbinical writings, alluding to the tables of the law presented to Moses on Mount Sinai, and in kabbalistic terms, the flaming letters of the covenant between God and Israel. There may also be found a Christological resonance in these words, however, suggested further in his comment that " $[M]$ on coeur a saigné, il saigne encore, il ne vit qu'avec l'espoir qu'on lui rendra un jour ses gallons, qu'il a noblement gagnés et qu'il n'a jamais souillés"144 (My heart bled and bleeds yet, it cannot live without the hope that one day the stripes will be returned, those so nobly earned and never tainted). The image of the bleeding heart, however, does not allude to Jesus on the cross but to his own wrongful sacrifice in the ceremony of degradation, a dishonour he hopes will be reversed, the language now shifting from its religious aura to that of military rehabilitation, with his officer's braids returned and his rank and name restored.

The idea of purgation from the taint of the false charges of treason and espionage ambiguously sits between three points of reference: the ancient Jewish notion of sin-offerings, the Christian myth of salvation through the bleeding heart of Jesus, and the military code of honour and rehabilitation. ${ }^{145}$ In another Sabbath letter, this one written on 12

142 Ecris-moi souvent, écris moi longuement, 133.

143 Ecris-moi souvent, écris moi longuement, 133.

144 Ecris-moi souvent, écris moi longuement, 133.

145 In his address to the First Zionist Congress in Basle on 20 August 1897, Max Nordau imagined the disappointments and disillusionments of the assimilated Western Jew when he or she discovers that their place in the society they believe to be home is questioned by those who dominate that nation, a realization that follows "recent tendencies," that is, the Dreyfus Affair: "The Western Jew has bread, but man does not live on bread alone. The life of the Western Jew is no longer endangered through the enmity of the mob; but bodily wounds are not the only wounds that cause pain, and from which one may bleed to death. The Western Jew meant emancipation to be real liberation, and hastened to draw the final conclusions therefrom. But the nations [i.e., the goyim,] made him fear that he erred in being so heedlessly logical. The magnanimous laws, magnanimously lay down the theory of equality of rights. But governments and society exercise the practice of equality of rights in a manner which renders it the same mockery as did the 
January, 1895, Alfred wrestles with his belief in God and his trust in the law, also ambiguously rendered as having its primary focus on French republican principles and more covertly in Jewish notions of justice and truth:

S'il y a une justice en ce monde, il faut espérer que la vérité éclatera bientôt et nous dédommagera de tout ce que nous avons souffert. ${ }^{146}$

If there is justice in this world, we must hope that the truth will break through soon and compensate us for all that we have suffered.

Here again he speaks of the redeeming light that will shine through the darkness to solve the mystery of who the real culprit is in the case of treason and espionage, but also, more allusively, he thinks religiously and Jewishly of the divine power of the law to set the world straight on its path of righteousness again, the hope for messianic rescue from darkness and ignorance, with the pains and humiliations serving here as sin offerings-that is, his and Lucie's part in fulfilling the terms of the brit, the covenant entered into at Sinai. But this is not the humble, patient suffering of Christian schemes of salvation, where the help comes from outside, aided variously by faith and good works, but rather in Hebrew concepts of participation by the individual and drawing on the stock of merit (zekhut) built up by all of Israel and the tikkun (gathering up of lost and hidden sparks) of each person and each generation through the performance of mitzvot (obligatory acts of charity, ritual gestures, etc.). Only in this way, Alfred says, can "cette énigme indéchifferable"147 (the indecipherable puzzle) be solved. A few days later he puts it this way:

appointment of Sancho Panza to the splendid position of Viceroy of the Island of Barataria. The Jew says naively: 'I am a human being, and I regard nothing human as alien,' the answer he meets is: 'Softly, your rights as a man must be enjoyed cautiously; you lack the right notion of honour, feeling for duty, morality, patriotism, idealism [everything, in fact, that Alfred Dreyfus lived and suffered for]. You must, therefore, hold aloof from all vocations which make possession of these qualifications as conditions [and when Alfred held himself aloof, he was mocked for having no feelings]." "Speech of Max Nordau at the First Zionist Congress, August 29, 1897," translated and reprinted on Mideast Web online at http://www.mideastweb.org (seen 12 December 2010).

146 Ecris-moi souvent, écris moi longuement, 141.

147 Ecris-moi souvent, écris moi longuement, 142. 
Cette nuit, je ne me suis encore endormi qu'à 2 heures de matin. J'ai pensé à toi, à vous tous, à cette énigme épouvantable que je voudrais déchiffrer... J'ai roulé dans ma cervelle mille moyens plus violents, plus extravagants les uns que les autres à vous indiquer pour déchirer le voile derrière lequel s'abrite un monstre. ${ }^{148}$

Tonight I could not fall asleep until 2 a.m. I was thinking of you, of all of you, of this horrible enigma that I wish I could decipher... I turned over in my head a thousand violent ways, each one more violent and extravagant than the other, to show you how to tear the veil behind which hides a monster.

Again, looking at this passage, what seems fairly simple in the beginning-his sleepless tossing and turning all night worrying about the puzzle of his accusation and punishment and the need to find out the identity of the real spy and traitor who committed the horrible crime he was found guilty of-turns out to be much more complex. There are two different problems to solve that keep him awake: one is the mystery of who brought about the false charges against him-later this will come to include the need to understand the reasons why his brother officers and the institutions he had so much faith in turned against him-and the other, how to communicate to Lucie the need to see behind the veil of mystery that lies over their lives.

While he calls upon a variety of discourses well known in literature and scholarship about different kinds of love, what he does not mention here explicitly is the other figure of sacrifice for love and purification through suffering, Lucie, his dependence upon her as his superior, godlike guide and nurse who under the awful circumstances of their plight must speak and act on his behalf in Paris. It is this "amour reciproque"149 that is at the heart of their new relationship, new for them, to be sure, but also new in literature, as it extends and transforms the Neoplatonic imagery of twelfth- and thirteenth-century troubador concepts of 
fin'amor, phenomena hinted at but never fully developed in the theoretical-autobiographical essays of Stendhal, Michelet, and others in the course of the nineteenth century, as well as in the novels of Balzac, Flaubert, and Bourget. Not only do sensual or sexual relationships merge with ideas of hypostatized friendship, as in the courtly love treatises, with Ovidean realism impregnating Christian spirituality with real passions of the flesh, but Alfred and Lucie's letters raised the domestic love of parents for children and concern for their education and future development to a level of psychological bonding and social reformation. These ideas are hinted at in the epistles; they are developed more fully in the prison cahiers.

I hinted earlier that one of the ways Alfred and Lucie find to discuss deeper meanings in their relationship and in the circumstances they are trying to work their way through was through their discussions - and even, at times, arguments-about how to bring up their children, discipline them, educate them, and prepare them for their futures, which may be always tainted with the charges against Alfred. It is the "gazouillement"150 (chirping or chattering) of the little ones that allows Lucie to act as a conduit, translator, and encoder of their and her own deepest feelings in letters she composes on their behalf. ${ }^{151}$ Her intentions are the best, both to cheer her husband with reports on the progress of little Pierre and Jeanne, to confirm their innocent and unmitigated love and longing for their pappa, and to express longings of her own that exceed the proprieties of middle-class etiquette; they also serve to provide an alternative topic of conversation than that of Alfred's sufferings in prison, in that the upbringing of the little ones is a joint responsibility and Lucie claims to be turning for advice and support to the father in these matters. That these reports mirror Alfred's own may not be a conscious aspect of her writings, but it is all too clear to the outside observer, looking back long after the events, that the cou-

150 Ecris-moi souvent, écris moi longuement, 150, 151, etc.

151 Chaim Vital in Sh'ar Ruah ha-Qodesh 5d (The Gate of the Holy Spirit) speaks of sifsufe 'ofot, the chirping of birds: "Sometimes they can be explained in another manner, for the soul of some righteous person comes from the upper world and is clothed in that form and image; it is not an actual creature or bird, but only appears and is seen in this way, and he reveals the secrets of Torah" (cited by Wolfson, Through a Speculum that Shines, 320). For Alfred and Lucie, the children are the visual manifestation of their act of love that produced Jeanne and Pierre, as well as the showing forth of the innocent honor they must protect. As in Vital's explication, their chattering can be translated into the deepest secrets of their parents' hopes and fears. 
ple's letters are also transcribed and their own intentions, whether fully known or not, have to be translated into terms appropriate to their social condition and to the special terms of the prison authorities.

But just as prison censors and politicians when asked to read the letters sympathetically could only find them tedious and vacuous, so Lucie-and sometimes Alfred himself-apologizes for the repetitiveness and clumsiness in expression.

Tu dois trouver mes lettres bien monotones, mon pauvre vieux, je me répète dans toutes, toujours je t'exhorte au courage. Je te vois te crisper en lisant ces lignes, mais je t'en conjure, maîtrise tes nerfs, pense moins à notre malheur. Je sais combine cela est difficile, car je passé moi-même par ces moments d'angoisse tels que je ne sais que deviner. ${ }^{152}$

You must find my letters very monotonous, my poor old fellow. I repeat myself in all of them, always exhorting you to courage. I can see you growing irritable in reading these lines, but I conjure you to control your nerves, think less of our misery. I know how hard that can be, for I too experience these moments of anguish, such that I only know will keep coming. ${ }^{153}$

The unusual term of endearment, "mon pauvre vieux," signals an odd tone to this apologetic. She already knows that Alfred craves her letters, receives them with ecstatic joy, and constantly rereads them, so her expressions of worry that he will be irritated by her repetitiveness are surely further indications of an encoded message between them. It is true, certainly, that she needs to keep saying over and over how much she admires his courage, just as she must remind him to avoid despair, to master his delicate nerves, and to remember that she shares with him all the anguish of the ordeal they are going through. But the repetitive-

152 Ecris-moi souvent, écris moi longuement, 151.

153 The syntax is obscure here, and Norbert Col suggests translating the last half of the last sentence: "for I too experience such moments of anguish that I can only make guesses." However, it is best that we simply recognize that Dreyfus is writing in pain and frustration. The amazing thing is how often, despite this, he breaks out of the doldrums and creates a virtual metaphysical conceit in praise of Lucie and of love. 
ness in the letters also indicates that what the husband and wife are doing is fighting against the system that separates them physically and tries to interrupt the easy, intimate flow of information between them. Since they cannot present to each other a running and logical pattern of statement and response, following a relatively orderly chronological framework, because delivery of mail is awkward, haphazard, and deliberately constrained, as well as being subject to prying eyes ever vigilant to find either or both of them involved in some sort of Jewish conspiracy against the army or the republic, they need to remind themselves that the letters do not form a record of daily events, whose progress can be tracked through cause and effect, but a steady stream of confirmations and reassurances of their mutual love and loyalty. They also need to communicate something else about their relationship, which, while it breaches many codes of social and domestic propriety, never can be seen to overstep the boundaries of their respect for one another.

This is the state we find them in as they write in the third stage of Alfred's hallucinatory journey to Devil's Island. ${ }^{154}$ From 18 January to 21 February, 1895, he is kept in the cells at Ile de Ré, the port of Saint-Martin, where an even more intense and humiliating regimen of body searches and incarceration is put in place. His letters are subject to greater scrutiny and delays, with all messages from other members of both the Hadamard and Dreyfus families forbidden. ${ }^{155}$ Duclert ${ }^{156}$ suggests that this harshness comes from an implicit wish by the authorities to drive Dreyfus to despair and eventually suicide. In the letters written during this period, the historian also opines, coming close to the inner dimensions of the husband and wife's communications, they seek "de construire un espace que leur soit proper et que personne ne pourra leur retirer"157 (to construct a space all their own and from which no one can remove them).

154 This is how Paul Bourget describes the trip across the Atlantic from France to America in his travelogue Outre-Mer: "Et dans la demi-hallucination que donne le bercement de la mer . . ." (Vol. 1, subtitled "Notes sur l'Amerique" [Paris: Plon, nd], 15). But if the gently rocking motion of the large cruise liner gentled Bourget into a semitrance of luxury, with time seeming to disappear in a haze of fine foods, music, and luxurious appointments, for Alfred Dreyfus, the tense, cramped journey to Devil's Island was the culmination of transformation of his life from normality to the bizarre and on to the nightmare of his imprisonment, isolation, and torture.

155 Duclert, Ecris-moi souvent, écris moi longuement, III, “Au bagne de l'Ile de Ré," 155-161.

156 Ecris-moi souvent, écris moi longuement, "Au bagne," 158

157 Ecris-moi souvent, écris moi longuement, "Au bagne," 161. 
Most of what they say to one another during this early period of their exchange of letters, if it can even be called that, remains similar in language, tone, and allusion to what has gone before. There are now and then, however, new points that strike us as different and consequently need to be discussed before we move into the main section of the letters, those written during the stay on Devil's Island itself.

For example, in a letter of 27 January, 1895, Lucie draws out the implications of earlier remarks on the mutuality of their love and loyalty by saying that, having passed through so much discouragement and worry already, they can only live in and through each other: "Il faut que nous vivions tous deux." 158 She also realizes that words alone cannot release him from his atrocious sufferings ("Je sais ... que toutes ces paroles ne t'enlevent pas les atroces souffrances actuelles") and that only his iron will and clear conscience will see him through, but even then, she adds, "Il faut que nous résistions tous deux" (We must be able to resist together, as a couple). How that can be done is hinted at in another of her closeto-articulate Jewish remarks, extremely rare according to Duclert, in an understatement of considerable interest. ${ }^{159}$ She asks Alfred whether she should arrange for a rabbi to visit him and offer consolation, stating quite clearly that she could, if he wanted, call on the aid of the very rabbi who married them and who is likely to have been a friend at least of her family, if not of their combined family:

Ne serais-tu pas heureux et désireux de voir un ministre de notre culte: dans ce cas, les secours de la religion nous sont une grande consolation. Veux-tu, si tu penses comme moi, demander au grand rabbin de France de designer un de ces messieurs pour te consoler, te réconforter? Et si tu ne peux écrire toi-même, veux-tu prier Monsieur le Directeur d'être assez bon pour lui écrire? ${ }^{160}$

Would you not be happy and desirous to see a minister of our cult; in that case the support of religion would be a great consolation. Do you wish, if you think as I do,

158 Ecris-moi souvent, écris moi longuement, 177.

159 Duclert, Notes, Ecris-moi souvent, écris moi longuement, 481, n. 21.

160 Ecris-moi souvent, écris moi longuement, 177, 178. 
to ask the Chief Rabbi of France to delegate one of his ministers to console you, comfort you? And if you do not wish to write to him yourself, could you entreat the Warden to be so kind as to write to him?

The language Lucie uses here is rather complex and weaves around several of the key issues we have been discussing already in regard to the mutuality of their relationship, the need to discover an appropriate lexicon and imagery to transmit their deepest feelings, of a sort normally hidden in bourgeois families of the period, and, in addition, this letter's special circumstances, wherein she knows that it will be scrutinized by prison censors and realizes that reference to Jewish issues would be extremely suspicious. Perhaps, still further, it is likely that in previous discussions, long before the crisis of his arrest and imprisonment, Alfred had expressed the need to remain aloof from institutionalized Judaism, particularly in regard to their family friendship with Zadok Kahn, Chief Rabbi of France, who had performed their marriage. The expression "un minister de notre culte" is not only neutral, it is an official formula, one that made the members of the Israelite persuasion in France come under the same rights and obligations as Protestants of all types. ${ }^{161}$ The syntax assumes a formality and indirection that is virtually absent in all her other letters, perhaps because, as we said, she is broaching very sensitive matters. Rather than speaking of their shared faith and the communal identity they share with their relatives and almost all of their friends, Lucie uses the virtually legalistic expression "minister of our cult." A meeting with a rabbi would, if he thinks as she does, offer consolation and comfort, and these terms, while certainly applicable in many instances to pastoral care offered by the Jewish ministry, are nontraditional expressions; more normally, the rabbi would come to pray with and help the despairing individual or family with ethical advice from modern or traditional books.

The oddest statement of all is the last sentence, wherein Lucie asks

161 Given the charged atmosphere of heightened anti-Semitism back in France, as well as elsewhere in Europe at this time, the word rabbi (other than in Zadok Kahn and Jew [Yehidi or Yid]) is laden with unsavory Eastern, Orientalistic and Semitic signals that neither Alfred nor Lucie would wish to trigger in the minds of their censors - or in the those of their non-Jewish supporters; similarly, a word like "prêtre" (priest), though specific to Catholic clergy, would not be appropriate to any form of post-Temple Judaism since the cult had fallen into desuetude and the role of priests (kohanim) had become at best honorific. 
indirectly if Alfred wishes to write to Rabbi Kahn himself or request that Monsieur le Directeur do so on his behalf. Either she is extremely naive or disingenuous here, as any such request from either prison or colonial officials, or even the Chief Rabbi himself in this regard would be turned down flatly as something contrary to the special regulations sent from Paris or due to the already manifest prejudices of the prison authorities, or she has some ulterior motive. As it is unlikely that either she or any of her advisers, such as Mathieu Dreyfus, have any intention of forcing the government to show its anti-Semitic hand more openly than it already has, the only other reason for this kind of request to Alfred from his wife must be an attempt on her part to signal that her closeness to him goes beyond the kind of love, loyalty, courage, and hope they have spoken of before in their letters: she now wants him to know that she will be performing the role of spiritual adviser, giving him-in the role of a nonChristian Boethius in prison-the consolation of Jewish philosophy. ${ }^{162}$

Just like the Shekhina, the divine shadow and presence which separates itself from the Godhead during the crisis of creation, when the universe contracts in the tsimtsum, leaving in the otherwise vacuous space and time retreated from by the deity a mysterious aura of spirit, so Lucie, in the shared suffering and martyrdom of Alfred, becomes his active other in the world he has been forced to leave. Like the Shekhina, who is God's female consort and co-creator, Lady Wisdom or Hochma, Lucie plays the role of Israel, the Bride of scriptures, that extension of the divine-separated from the infinite En-Sof (world without end) by the cosmic energies of the sephirot-acting and suffering in this world, ha-olam hazeh. It is the duty of Israel embodied and unified in the Shekhina to gather up all the sparks of primal energy scattered and hidden after the breaking of the great vessels in the moment of separation-the Big Bang-the recollecting of these shells of light constituting the tikkun ha-olam, the repair and correction of the broken world, thus preparing for the moment when God and his Shekhina can join together again, inaugurating the messianic age. ${ }^{163}$ The sparks

162 André Maurois recalls being at a Christmas party when he was five or six years old when "I learned from another child, who was beside me in the church, that my parents were Jews and that this was an astonishing fact" (Call No Man Happy, trans. Denver and Jane Lindley [London: Jonathan Cape, 1943], 11).

163 Ouaknin says, following Rabbi Nahman, "Il s'agit de la Chevira hakélim, 'la brisure des vases' . . . Après le Tsimtsoum, la lumière divine jaillit dans l'espace vide sous forme de rayon en ligne droite. Cette lumière se nomme Adam Qadmon, cést-à-dire l'Homme primordial" (It is a question of the Shevra 
that remain after millennia of regathering are now mostly those that emanate from the other side, sitra achra, which though malevolent, hostile, and pernicious nevertheless contain within them aspects of eternal energy and power. For Alfred and for Lucie, confronted by "la machination infernale," ${ }^{64}$ the task remains to soldier on bravely and stoically through all "les tortures morales," 165 until the enigma is broken and the light of truth breaks forth again to free them.

\title{
Lo dibera Tora k'lechon bene adam ${ }^{166}$
}

\begin{abstract}
Les Hébreux, en fait d'œuvres scéniques, ne paraissent point avoir atteint l'idée du drame complet, où l'on vise surtout à mettre l'action devant les yeux du spectateur, et où la vraisemblance, sous le rapport des changements de lieux doit être observée.
\end{abstract}

-Ernest Renan ${ }^{167}$

hakelim, 'the breaking of the vases or vessels' . . After the Tsimtsoum, the divine light leaps forth into empty space in the form of a straight line. This light is called Adam Qadmon, that is, "Primordial Man"” (Le livre brûlé, 381).

164 Ecris-moi souvent, écris moi longuement, 181.

165 Ecris-moi souvent, écris moi longuement, 180.

166 Rabbi Nachom de Gamzo: "Torah does not speak in the language of man," a statement opposite to many Christian exegetes who say that the Bible speaks in the language of men and therefore must be read allegorically in order to read the language of God, and therefore says Ouaknin, "Everything is essential, each letters possesses a vital sense and importance, and everything needs to be interpreted, conjunctions and prepositions, punctuation marks and rhetorical markers, the size, thickness, and shape of letters, every jot and tittle" (Le livre brûlé, 116). In the case of Alfred and Lucie Dreyfus, we cannot go so far, but we will try to explode the text out of its linearity-little as there is of it left in the conditions they write in - to discover something of vital importance.

167 "The Hebrews, in regard to scenic plays, do not at all seem to have reached the idea of a complete drama where the chief aim was to put an action in front of the eyes of a spectator and where verisimilitude in regard to the changes in place was to be observed": Renan, Le Cantique des cantiques, 50. What Renan means here, typically in nineteenth-century terms, is that ancient peoples, especially the Jews, did not know how to mount a middle-class realistic play, with coherent actions performed before an audience with suspended disbelief in its artificiality and where the imitation of reality was to be complete. None of this, of course, would be seen in a Shakespearean play or theatre, not because neither he nor his audience was mature enough to conceive of such a performance but because the conventions of drama for the most part-in most times and in most places - operated on different principles than those developed eventually in the brief period of classical Greek tragedy and new comedy. Theatricality tended to be envisaged rather as ritual, ceremonial festivals, often with a transformative or shamanistic purpose-initiations, metamorphoses, conjuring forth of phantom ancestors-and consequently the emergence of monotheistic Judaism, with its abhorrence of idol worship and other forms of magic, recreated (midrashed) its own archaic cultural artifacts and the customs of neighboring civilizations, creating new inward dramas and performative rituals. See José Faur's forthcoming The Gospel 
Because Lucie cannot write to her husband about any of the efforts being made on his behalf other than in vague hints, such as "[c]omme on apprécie dans ces moments terribles les personnes dévouées et elles sont en nombre très grand"168 (as one comes to appreciate in these terrible times, there are many people devoted to you, a very great number), or even about who is making these efforts, and how many supporters there actually are beyond the family members he already knows about, she must return to the interchange of comments each makes on how they read and recall each other's letters. Alfred writes on 31 January, 1895, that he reads and rereads all her letters, finding in them "un echo de vous tous" ${ }^{169}$ (an echo of all of you), this all meaning Lucie, the children she writes for from their supposed dictation, and other close relatives who have sent him epistles of their own. Then he describes the process more minutely:

Je relisais ta lettre quatre ou cinq fois, je m'imprégnais de chaque mot,- - peu à peu les mots écrits se transformaient en paroles dites. . . il me semblait bientôt t'entendre me parler près de moi. Oh! musique délicieuse qui allait à mon âme! Puis depuis quatre jours, plus rien, la morne tristesse, l'épouvantable solitude. ${ }^{170}$

I reread your letter four or five times. I was impregnated by each word,- - little by little written words transformed themselves into spoken statements ... soon it seemed that I could hear you speaking close by me. Oh! what delicious music that came into my soul! Then for the four days, nothing more, the unbearable solitude.

According to the Jews, in section III of which he discusses the theatricality of Christianity and the rationality and legal disposition of Judaism; cp. my Festivals of Laughter, Blood and Justice (London, ON: Sussco, 2008). With the re-valuation of notions such as time, space, personhood, and reality, the rabbinical imagination passed on to men and women such as Alfred and Lucie Dreyfus an ability—and an anxiety—in playing out the roles that have been imposed on them by hostile and alien societies.

168 Ecris-moi souvent, écris moi longuement, 183.

169 Ecris-moi souvent, écris moi longuement, 184.

170 Ecris-moi souvent, écris moi longuement, 184. 
The meditation on the epistle with its iterated reading ${ }^{171}$ causes a metamorphosis in his perception of reality. As in kabbalistic exercises to achieve devekut (cleaving to the divine object), Alfred through intense focusing turns the inscribed letters on the paper into audible sounds, Lucie's own voice, standing close to him, speaking from within. It is a sacred music, a spiritual melody, like the heavenly choir of angels that sings around the enthroned Godhead. But harsh reality returns: because of the absence of further letters, ${ }^{172}$ he experiences the closing down over him of solitude. In this metaphor of verbal impregnation, used again on 14 February, ${ }^{173}$ when he speaks of being impregnated by her face (" $\grave{a}$ m'imprégner de ton visage"), ${ }^{174}$ the reference is to at least two places. The first is quite Christian, deriving from the liturgical hymns and iconography associated with the Annunciation, wherein the angel Gabriel, on behalf of God the Father, impregnates Mary with the fecundating word to make her conceive Jesus in her womb in a spiritualized sexual act manifested in the passage of the Verbum into her womb as light passes through a glass, and often spoken of in the ingenious metaphysical conceits of the Baroque Era of the seventeenth century. The other source for this witty language of fertilization and conception through words as letter combinations, sound constructs, and thought containers appears in kabbalistic texts, especially those associated with the Song of Songs (Shir ha-Shirim) ${ }^{175}$ Whether the mixing and matching of Christian, Jewish, and secular love imagery should be credited to some mystifying hybridity, philosophical ambiguity, or deliberate personal conflations, ${ }^{176}$ the point is that Alfred and Lucie create a language of love far different from anything else to be found amongst their contemporaries. ${ }^{177}$

171 Leo Strauss explains that "the purpose of repeated conventional statements is to hide the disclosure, in the repetition, of the unconventional views" (Strauss, Persecution and the Art of Writing, 64).

172 On absence in a text as the demand for filling in, for something to be created in and through the silence of its apparent inanity; see Ouaknin, Le livre brûlé, 112.

173 Ironically, as we read this, it is St. Valentine's Day, but it is unlikely that anyone in France would have recognized this more American and British celebration until a hundred years later when commercial exigencies started to make it popular in the hexagon and elsewhere on the Continent.

174 Ecris-moi souvent, écris moi longuement, 200.

175 Alfred Dreyfus may have read about the Song of Songs in the commentary by one of his favourite authors published in 1860: Ernest Renan, trans. and commented, Le Cantique des Cantiques (Paris: Arléa, 2004).

176 These issues are discussed in Sandrick Le Maguer, Portrait d'Israël en jeune fille: genèse de Marie (Paris: NRF/Gallimard/L'Infini, 2008).

177 Faur cites the midrashic study of The Song of Solomon, Shir ha-Shirim Rabba VIII.1(2) 39b: 
And of this solitary confinement, always with the silence of guards who do not speak to him, he feels his heart bleed and his nerves shiver with pain.

Toutes les fibres de la sensibilité tressaillir, l'une après l'autre ... souffrir enfin le long martyre du cour ... Voilà ce qu'il y a de vraiment épouvantable! $!^{178}$

All the fibres of my sensibility shiver, one after the other ... to suffer finally the long martyrdom of the heart ... Here it is, what is truly unbearable!

Most remarkable here is the way Dreyfus describes his psychological and emotional condition, something we shall see him do with ever greater insistence and detail in the letters from Devil's Island. The term sensibilité can, in a general way, be matched to the English term sensibility, with its gamut of meanings from a positive notion of being intelligent and filled with common sense to the more negative connotations shown in Jane Austen's novel Sense and Sensibility, wherein the term is contrasted to common sense and reasonable behaviour; sensibilité thus covers the same ground as sentimentality in all its superficial qualities. But at its core, the word also can have a more technical sense, that of the sensorium, the body's nervous system and its processes of emotive responses to inner and outer stimuli. Not by chance, I would say, one of the exemplary citations in the Petit Robert dictionary comes from the son of Dreyfus's former teacher of mathematics and chemistry at lycée, the novelist and psychologist Paul Bourget: ${ }^{179}$ "un je ne sais pas quoi de frémissements qui trahissait une sensibilité restée vive et neuve" (an indefinable something of quivering or trembling which betrayed a sensibility still alive and new).

More specifically, in this part of his letter, Dreyfus is referring to his nervous system, with each of his nerves being tortured by the long or-

"Borrowing from Song of Songs (8:2) the rabbis referred to [the revelation of the Law at] Sinai as 'my mother's house' because, they explained 'it was there where Israel was gestated, as a newly born baby"' (The Horizontal Society, Section IV, Introductory Remarks).

178 Ecris-moi souvent, écris moi longuement, 185.

179 Fuller discussion of the relationship between Alfred Dreyfus and these two Bourgets, father and son, will appear in the next book in this series. 
deal. In the nineteenth century, we should recall, what we assign to mental states, hormonal imbalances, and other conditions of emotional instability were considered due to overly excitable nervous constitutions or the draining away of nervous energy, as in enervation. ${ }^{180}$ Another word that Alfred uses in self-diagnosis of this long-term condition being exacerbated by the moral tortures in prison is éréthisme, from the Greek word erethismos (irritation), which takes on the medical sense of a violent exaltation, excessive tension, sometimes, and a state of extreme excitability and irritability associated with the heart as well as with the mind. Here, then, on 4 November, 1897, almost speaking of himself in the third person, Alfred self-diagnoses the ætiology of his mental illness:

Mais la trop longue souffrance, une situation épouvantable, le climat qui à lui seul embrase le cerveau, si tout cela ne m'a jamais fait oublier aucun de mes devoirs, tout cela fini par me mettre dans un état d'éréthisme cérébral et nerveux qui est terrible. ${ }^{181}$

But the excessive suffering, a terrifying situation, the climate which by itself is enough to set my brain on fire, which all by itself never made me forget any of my duties, all that finished by putting me into a state of cerebral and nervous erethism which is terrible.

The treatment he recommends for himself is silence-but how ironic, when his whole life on Devil's Island is one of enforced, obligatory silence on the part of all the twelve to fifteen guards who watch him day and night. The silence he needs is more than the absence of disturbing noise, confusing and irritating: it is the peaceful, warm home life with Lucie and the children. Without their quiet conversations by the fireside, the prognosis is dire, if not fatal. On 24 November, 1897, he tells Lucie, again withdrawing into the self-objectifying third person, that "le corps, le cerveau, le coeur, tout est épuisé" (the body, the brain, the heart, all are exhausted), and what remains is his soul: "L'âme est restée intangi-

180 This old psychiatry is still around in many common expressions, such as "to have a lot of nerve" or "to lose one's nerve," even in "to be nervous" and "to be nervy."

181 Ecris-moi souvent, écris moi longuement, 389. 
ble, toujours aussi ardente, la volonté inébranable, forte du droit de tout être humain à la justice et à la verite, pour lui, pour les siens"182 (The soul has remained untouched, as ardent ever, the will unshakeable, strong in the right of all human beings to have justice and the truth, for himself, for his own [family]). ${ }^{183}$

Alongside these descriptions of his painful and excitable nerves, which Lucie knows Alfred has always suffered from, there is also the question of the processes of reading and interpreting the letters, the language itself taken as an index of their inner and outer states. Their writings - and in Alfred's case there are also journaux, carnets, and cahiers to be considered-may be examined as external brains, as we will do in the next chapter.

In the same letter of 31 January, 1895, considered above, Alfred apologizes for his style, which he describes as "baroque and décousu"184 (baroque and disconnected). Another way to speak of this conceited, baroque, witty way of writing and reading texts is to think of it in Jewish terms, as part of the invisible-visible dialectic of confronting words on the page with questions that challenge their status as linear and logical communication, that force the words on the page to have a substance and a volume, a volume which, as soon as perceived, spills out of the passage like water bursting from a dam, in an inexhaustible outflowing

182 Ecris-moi souvent, écris moi longuement, 392.

183 Faur cites Josephus, Contra Apion, I.60: "The result, then, of our thorough grounding in the laws from the first dawn of intelligence is that we have them, as it were, engraved on our souls" (The Horizontal Society, Section IV, Introductory Remarks). Note that this polemical defense of Judaism was edited by Théodore Reinach, with a French translation by Léon Blum in 1930, both leading Dreyfusards during the affair. Expounding on Josephus's metaphor of engraving the law on the soul, Faur calls it "a kind of ontogenetic intuition, continuously activated by Tora[h] learning and practices." Although Dreyfus did not continuously study the holy books, the deep impressions of rabbinical thought and practice were part of his mental makeup. The ordeal of his nightmare triggered archaic patterns of feeling, thinking, and writing inculcated in the ways he learned to speak and think at home, whether or not he was actually taught by his father or a Hebrew teacher. Those archaic memory patterns become the sod, the secret of his soul, although the precise and substantive knowledge was at best confused and at worst missing. Through the hints and the cryptograms (remez), he was able, in the depths of his soul, where the darkest secrets were hidden, "to dig up stems and innovative (doctrines) and corollaries [from the root principles]," but to have understood the laws and how to apply them, he would have had proper rabbinical training. "To accomplish this [Dreyfus would have needed] in depth analysis and judicial theory (sebara)" so that he could not condense or expand, only touch them theoretically and draw archaic strength, enough to survive. Cf. The Horizontal Society, Section IV, Section 4. One can know the truth but not necessarily the whole truth and nothing but the truth.

184 Ecris-moi souvent, écris moi longuement, 185. 
of creative energies. ${ }^{185}$ This overly intricate and uncoordinated writing, so far as Alfred sees it at first, is only a product of his mental or moral tortures. The conditions of his imprisonment have upset all his normal skills and intellectual talents.

Je ne sais plus écrite, les mots ne me viennent plus, tant mon cerveau est délabré. Il n'y a plus un point fixe dans ma tête: l'espoir de connaître un jour la vérité, de voir mon innocence reconnue et proclamée. C'est ce que je balbutie nuit et jour, dans mes rêves comme dans mon réveil. 186

I no longer know how to write, words no longer come to me, so much is my brain torn to shreds. There is no longer just one fixed point in my head: the hope to know the truth one day, to see my innocence recognized and proclaimed. That's what I stammer night and day, in my dreams as in my waking.

The more he writes about what is going on in his head, and the more he tries to answer Lucie's questions and challenges in the letters that manage to arrive in his prison cell, the more the very act of repeating his words over and over with minor variations generates friction that ignites the charge inherent in the thoughts, so that for a few moments, now and then, the light flashes out and he-and Lucie-glimpse the inner truth of a transcendent experience.

On 10 February, 1895, somewhat more controlled, Alfred writes that he is going through something beyond the talents of any novelist to describe. "Jamais romancier, si riche que soit son imagination, n'aurait

185 Ouaknin tells us, "Dans la conception talmudique de linterprétation, le Texte est indéfini, ouvert à des interprétations toujours nouvelles . . . . celui-ci demeure inépuisable et ouvert parce que sa structure est celle du 'visible-invisible"' (In the talmudic conception of interprétation, the Text is indefinite, open to interpretations [which are] always new ... this [Text] remains inexhaustible and open because its structure is that of the 'visible-invisible') in Le livre brûlé, 246. Ouaknin here cites Umberto Eco, L'CEuvre ouverte (Paris: Seuil, 1965) and Gershom Scholem, La kabbale et son symbolisme (Paris: Payot, 1975). The visible text has meaning only when it is interpreted, that is, when the hidden or invisible meaning is made manifest in the explosive act of questioning its very strictures. Ouaknin puts it this way in italics to emphasize the centrality of the idea: "L'interprétation n'est pas seulement perception, elle est constitution du sens" (Interpretation is not only perception; it is the constitution of sense) in Le livre brûlé, 247.

186 Ecris-moi souvent, écris moi longuement, 185. 
pu écrire une historie plus tragique"187 (Never would a novelist, however rich his imagination might be, have written a more tragic history than mine), a statement showing that he realizes how awkward and difficult it is to transmit a valid picture of his condition with the inadequate language, even if there were literary precedents, at his disposal. But not only rhetoric and novelistic discourses fail to provide the terms he so longs to find; it is also a failure of the imagination, his as much as that of his mentors and models. ${ }^{188}$

Then, on the same day, and thus with no chance of her having seen his letter, Lucie responds in similar terms, manifesting her capacity to anticipate as well as echo his complaints and cries of anguish when she says that she cannot understand why her letters do not arrive regularly, the rigor of the censorship seeming excruciatingly severe since all she does is write her true feelings to her beloved husband, and then says, in a passage previously edited from the published letters, "Je m'imagine aisément les souffrances que tu as dû endurer étant ainsi sans nouvelles." 189 She has used the same word imagination, and says that through her own imaginative faculties, she can see and feel his sufferings - that is, that for all his fears of inadequacy of style and rhetoric, she has understood. She has picked up the hints, followed the allusions, rearranged the confused and baroque utterances, and created a forceful picture in her mind. Neither of them engage in a systematic process; they are not metaphysical poets or specialists in the occult, and the disorderly writing and arrival of letters ensures that what we finally see ${ }^{190}$ can only be understood in hindsight when our own minds can midrash the collection. ${ }^{191}$

187 Ecris-moi souvent, écris moi longuement, 198.

188 Inadequacy and failure are not, however, absolute, not sins staining the soul of the feeble man crying out in despair. Benmozegh points out that "For the Kabbalah, just as imperfection is always mixed with holiness, so truth is perpetually mixed with error. The one is the husk or outer covering, the other the inner reality, the quickening spirit" (Israel and Humanity, 96).

189 Ecris-moi souvent, écris moi longuement, 199.

190 Until there is a complete edition of all the letters of Alfred and Lucie Dreyfus, including those written before the affair, everything we say has to be tentative, as well as speculative.

191 Faur: "There is a huge difference between rational idealism and Tora[h]. One exposes the basis of perfect demonstration (apodeixis), the other proposes. Rational idealism demonstrates; Hebrew Scripture persuades. Greek 'knowledge'(episteme) closes the subject; Hebrew 'wisdom' (חכמה [Hochma]) inaugurates a dialogue ..." The Horizontal Society, Section IV, 46. Dreyfus tries to be assimilated perfectly to Greek knowledge, both technē and episteme, but he finds it constructive and uncomfortable and reaches out towards חכמהז, Lady Wisdom, and Shekhina, his wife Lucie. 


\section{PART 3: INTERNAL PAINS AND EXTERNAL BRAINS}

Persecution ... gives rise to a peculiar technique of writing, and therewith to a peculiar type of literature, in which the truth about all crucial things is presented exclusively between the lines. That literature is addressed, not to all readers, but to trustworthy and intelligent readers only. It has all the advantages of private communication without having its greatest disadvantage-that it reaches only the writer's acquaintances. It has all the advantages of public communication without having its greatest disadvantage-capital punishment for the author.

-Leo Strauss ${ }^{192}$

Study itself was viewed as a mode of "visual meditation" a technique known in medieval Christian mysticism as well-in which there is an imaginative recreation of the prophetic vision within the mystic's own consciousness. -Elliot R. Wolfson ${ }^{193}$

The close to 250 pages of selected letters included in Ecris-moi souvent, écris-moi longuement can be seen to reiterate many of the same themes, images, rhetorical ploys, and cris du coeur registered already in the letters of the opening section of Vincent Duclert's book. My focus here is on a few key epistles wherein Alfred engages in sustained descriptions and self-examination of his fragile mental state and then Lucie mirrors his language, encourages him to talk out his pains and humiliations, and implicitly and quietly leads him towards resignation, reconciliation, and relief from the most acute of his fears and anxieties.

On 27 April, 1895, Alfred writes to Lucie from Iles du Salut (neither of them ever uses the term Ile du Diable) ${ }^{194}$ that she should never ask on his behalf for the government to show grace or pity ("que tu ne demandes pour moi ni grâce ni pitie") but only that they carry out their investigations to the uttermost ("à outrance"). ${ }^{195}$ For no matter how awful his

192 Leo Strauss, Persecution and the Art of Writing (Glencoe, IL: The Free Press, 1952), 26.

193 Wolfson, Through a Speculum that Shines, 331

194 Ecris-moi souvent, écris moi longuement, 228.

195 Ecris-moi souvent, écris moi longuement, 229. 
conditions are, he will not beg from them anything other than truth and justice. This is a very Jewish position, and appears in Amos Oz's work wherein a character says to his son after escaping the Holocaust, "Weakness is a sin." Nevertheless, Alfred knows that his situation is bleak and that Lucie, reading his letters, with their complaints and shattering cries of pain, will misunderstand him as asking for immediate release, no matter the nature of the conditions imposed on such a pardon or grace. Whatever his physical or moral torments, he pleads with her that she should only protest "mon innocence jusqu'à mon dernier souffle"196 (my innocence down to my last breath). That leads to another confession of faith, expressed in muted Jewish terms:

Mais s'il y a une justice en ce monde, il me semble impossible, ma raison se refuse à y croire, que nous ne retrouvions le bonheur qui n'aurait jamais dû nous être enlevé. ${ }^{197}$

But if there is a justice in this world, it seems to me impossible, my reason refuses to believe that we will not regain our happiness which should never have been taken away from us.

The justice he seeks is on earth, if it is real, will be manifested in real historical terms and times, and he cannot believe otherwise-his unstated but implicit Jewish confidence in the almighty power of the law will not let him - than that he and Lucie will be happy again, the crime committed against them being totally unjustified. And yet, for all this faith and confidence, Alfred tells Lucie he is all too aware that the letters he writes are frightening to her and may convey the wrong impression of his firmness of heart and soul.

Je t'écris certes parfois des lettres exaltées, sous l'empire d'impressions nerveuses extrêmes ou de dépression physique considérable; mais qui n'aurait pas de ces coups de folie, de ces révoltes du cour et de l'âme, dans une situation aussi

196 Ecris-moi souvent écris moi longuement, 229.

197 Ecris-moi souvent, écris moi longuement, 229. 
tragique, aussi émouvante que la nôtre $?^{198}$

Certainly I sometimes write you excited letters, under the domination of extreme nervous impressions or of considerable physical depression, but who would not suffer acts of madness or rebellions in the heart, in a situation as tragic and horrible as ours?

He is trying desperately to ask her to read between the lines, or more accurately, inside the lines, to see that for all his agony and anxiety, he is not insane, and that she has to work with him in investigating the source of the charges against him. ${ }^{199}$ He wants to live to take part in the public restoration of his good name, and to do this he needs her help, her support, and her understanding. She cannot fall into the trap of thinking he has gone mad or dismissing his extreme statements as marks of folly or despair. He therefore again asks,

Et puis, toujours seul, en tête-à-tête avec moi-même, livré à mes tristes pensées, sans nouvelles de toi, des enfants, de tous ceux qui me sont chers depuis plus de deux mois, à qui confierais-je les souffrances de mon cour, si ce n'est à toi, confidente de toutes mes pensées? ${ }^{200}$

And then, always alone, in conversation with myself, given over to my sad thoughts, without news of you, the children and all those who have been dear to me for more than two months, to whom can I entrust my heart's sufferings, if not to you, confidant of all my thoughts?

Alfred then moves to a realization, implicit earlier, as we have seen, that it is not he alone who suffers or Lucie who suffers in her own way because of his condition, but that they suffer together, within one an-

198 Ecris-moi souvent, écris moi longuement, 229.

199 Strauss, Persecution and the Art of Writing, 26. "Another axiom: 'a careful writer of normal intelligence is more intelligent than the most intelligent censor. For the burden of proof rests with the censor."”

200 Ecris-moi souvent, écris moi longuement, 229. 
other, a metaphysical and psychical process expressed in his concern for the future of their two children:201

Je souffre non seulement pour moi, mais bien plus encore pour toi, pour nos chers enfants. C'est en ces derniers, ma chérie, qui tu dois puiser cette force morale, cette énergie surhumaine qui te sont nécessaire pour aboutir à tout prix à ce que notre honneur apparaisse de nouveau, à tous sans exception, ce qu'il a toujours été, pur et sans tache. ${ }^{202}$

I suffer not only for myself, but indeed much more for you, for our dear children. It is from them that you, my darling, must draw out the moral force, the superhuman energy that you must have to bring this about at any price that are indispensable to you, so that at all costs our honor will be visible again, to everyone with exception, as it has always been, pure and unsullied.

The designations of moral strength and superhuman energy can, of course, be registered simply as exaggerated rhetoric to impress on Lucie the urgency of the situation. ${ }^{203}$ In context, in the pattern of allusions this study is uncovering, the expressions also describe a more kabbalistic power that derives from the performance of the mitzvot. Suffering is not the passive phenomenon it is in Christian mysticism, where it prepares the faithful soul for the reception of a heavenly grace, either after

201 Compare this mode of indirection and deference of communications with what Strauss sees in Maimonides's Guide of the Perplexed. There, Rambam calls his book both a treatise (ma'amar) and also something spoken in conversation, part of fleeting, passing speech. "If the Guide is, in a sense, not a book at all, if it is merely a substitute for conversations or speeches, then it cannot be read in the way we may read, for instance, Ibn Sina's Al-Shifâ, or Thomas Aquinas's Summa Theologica" (Strauss, Persecution and the Art of Writing, 47, 48). How then is the Guide written, and how do we read it? In the same way, I suggest, as we do the letters of Alfred and Lucie Dreyfus. "The Guide is written in the form of letters addressed to a friend and favorite pupil, Joseph. By addressing his book to one man, Maimonides made sure that he did not transgress the prohibition against explaining ma'aseh merkebah [esoteric discussions on the description of the Heavenly Chariot in Ezekiel] to more than one man. [He mentions too that] Joseph possessed all the qualities required of a student of the secret lore and explains the necessity of written communication by his pupil's departure ... [and] Joseph's departure ... was the consequence of his being a Jew in the Diaspora .... Only the necessity of saving the law can have caused him to break the law" (49).

202 Ecris-moi souvent, écris moi longuement, 229.

203 Strauss, Persecution and the Art of Writing, 26. 
life or perhaps within it. In rabbinical thought, suffering is an active process of struggling to attain justice, to fulfil the commandments of the law. By drawing on the innocence of their son and daughter, Alfred says, Lucie can carry out the tasks Alfred is unable to do, and her actions will further energize the husband to endure his tortures and survive until the mission is accomplished: the charges dismissed, the verdict overturned, and the sullied family name returned to its former glory

By late April and early May 1895, Lucie writes a series of letters that she holds back until she can send them all at once, thus creating, as Duclert suggests, a virtual diary or journal of her own. In these letters, amongst other matters, she tells of the birthday of her father, David Hadamard, a happy occasion marred by sad thoughts and worries about Alfred, indeed of a collective grieving. Again, rather than an actual narrative or list of events that occur from day to day, Lucie's letters speak in more general terms of feelings and aspirations, sadness and frustrations. On 4 May, 1895, for example, she writes:

La bizarrerie de l'existence fait que le corps vit indifféremment de toutes les souffrances morales, c'est une sorte de machine qui [sait] ${ }^{204}$ de routine et accomplit machinalement les exigences de la vie. ${ }^{205}$

The bizarre nature of existence makes the body live regardless of all moral or psychical sufferings; it is a sort of machine that knows the routine and performs all the exigencies of life mechanically.

Those details of act, emotion and situation that constitute the normal content of a diary or a personal letter are not dealt with because, for her, life is a mechanical process wherein actions seem almost to perform themselves, normal feelings are numbed or felt at a level of virtual unconsciousness, and people, places, and events simply pass unnoticed. Like Alfred, she finds more reality in the writing and reading of letters than in the physical existence of things and persons around her. While

204 The suggested missing word is from Duclert. The whole letter is printed here for the first time. Ecris-moi souvent, écris moi longuement, 231.

205 Ecris-moi souvent, écris moi longuement, 231. 
this is not strictly true, the statement does describe one whole aspect of her life. The reality is more complex: on the one hand, because she is well attuned to the needs of her children and her parents' home, where she has now moved and, on the other, because in a substantial part of her daily life she is devoted to Alfred's release and working diligently with his brother Mathieu and others to lobby the government and to supervise detectives hired to investigate what the police or other agents refuse to look into. If read sequentially as a record of cause and effect or logically as a rational argument, her letters collapse under the weight of contradiction and non sequitur. ${ }^{206}$ They need to be perceived in the way of Talmudic midrashing, where events are replaced by figurative, encoded anecdotes (aggadot), chronological sequencing of time by intertextual associations, ${ }^{207}$ and coherence of expression by suspensions and fragmentation that come together only occasionally in the text itself but much more often in the minds of the students learning. ${ }^{208}$

206 On the use of contradictions and non sequiturs, Strauss says, "To speak of the same subject in a contradictory means on pages far apart from each other; to make one of the two contradictory statements in passing . . . incidental ... not directly to contradict but to deny the first statement's implications, to seem to repeat the first statement but to add or omit an apparently negligible expression . . . to be introduced between the two contradictory statements an intermediary assertion which, by itself not contradictory to the first statement, becomes a contradictory to it by the addition, or the omission, of an apparently negligible expression; the contradictory statement creeps in as a repetition of the intermediary statement" (Strauss, Persecution and the Art of Writing, $70,71)$. But at the same time, we should recall what Wolfson points out, "We must be aware of the fact that any given culture fosters divergent views that are not always logicially consistent. Indeed, different impulses can be operative within a culture at the same time without necessitating a resolution that adopts one alternative to the exclusion of the others" (Through a Speculum that Shines, 27).

207 Following his rabbinical authorities, Ouaknin argues that at a certain point in reading "histoire et interprétation sont deux termed inseparable l'un de l'autre" (history and interpretation are two terms that cannot be separated) in Le livre brûlé, 258. Time being in man and man being in time, history cannot be measured only by one, making the individual dependent upon the chronological passage of years and centuries flowing forward from the past through the present into the future; instead, by acts of interpretation-midrashing of memory, experience and action-time reveals its meanings in regard to eternity and infinity. The Jew can reach back into the past and draw forth strength and courage, as well as the honor and loyalty won by good deeds of ancestors, just as each small mitzvah, even when performed only through intention when the circumstances do not permit otherwise, still adds to the patrimony (zekhut) to be passed on to future generations. In this sense, time is reversible and can transform the outcome of actions and decisions taken.

208 "But how does he proceed," asks Strauss following Rambam's argument in the Guide of the Perplexed, "if the pupil fails to understand the hint? He will simply stop. This does not mean that he will stop talking. On the contrary, since by suddenly becoming silent he would perplex the pupil without being of any help to him, he will continue talking by giving the first, rather revealing sentence a more conventional meaning and thus gradually lead him back to the safe region of accepted views" (Strauss, Persecution and the Art of Writing, 53). 
At that point, Lucie turns from her concern for the relationship between herself and her husband as though they reached an impasse, and so to avoid provoking an epistemological crisis that might harm the two of them or open their conversation to abuse by the scrutinizing censors who read and assess all their communications, she begins to speak of their innocent children. ${ }^{209}$ Such maternal concerns and the recording of infantile prattle are, as we have already remarked, hints of something beyond, which at the moment Lucie dares not express openly, both because she fears the reaction by the military censors and because she intuits the need to tread very slowly and softly on issues that would upset her husband. ${ }^{210}$

On 8 May, 1895, Alfred writes one of the letters which contain his lament for the physical distance between them, but also his realization that, thanks to the sacred mission they have each undertaken to accomplish, "nous nous réfugerions dans notre affection mutuelle, dans notre amour grandi par des événements aussi tragiques"211 (we would take refuge in our mutual affection, in our love enlarged by such tragic events). On 11 May, Lucie writes-one can hardly say responds, since letters cross and arrive out of sequence-"Tu sais que mes pensées sont les tiennes et que nos souffrances sont communes"212 (You know that my thoughts are yours and that our sufferings are common) - that is, that she occupies the same textual space Alfred does, a locus of refuge created by love and an area of understanding that needs only the barest of hints to spark off understanding in the other. "I spend hours in reading and re-reading your fine letters," writes Lucie on 7 June, 1895;213 "they are my consolation, waiting until I will have the joy of seeing you return." Then she adds, showing her part in the exchange: "I will tell you what I think, that which I cannot stop writing to you: I have hope, a great deal of hope. I have the conviction that all will come out well,

209 "But a good writer will never submit to the ordeal of indulging in insignificant talk. Consequently, after having given a hint which refers to a certain chapter of the secret teaching, he will write some sentences which at first glance seem to be conventional but which on closer examination prove to contain a new hint, referring to another chapter of the secret teaching" (Strauss, Persecution and the Art of Writing, 54).

210 A saying by Ibn Ezra: "He who understands should be silent" (cited by Leo Persecution and the Art of Writing, 184).

211 Ecris-moi souvent, écris moi longuement. 232.

212 Ecris-moi souvent, écris moi longuement. 235.

213 Ecris-moi souvent, écris moi longuement. 243. 
that your rehabilitation will be a brilliant explosion of light and life will preserve you again in goodness." 214

The allusion to the explosive, lightning flashes that characterize kabbalistic reading services here are by now familiar to their letters, as much so as the highly intimate, perhaps repressed innuendos in their description of their way of transmogrifying the reading itself into a sexual encounter: ${ }^{215}$ "Il me semble," Lucie writes on 8 July, 1895, "que je t'entendais parler, que ta voix chérie résonnait à mes oreilles; il me parvenait enfin quelque chose de toi, tes pensées si nobles et si belles venaient se refleter dans mon esprit"216 (It seems to me that I hear you speak, that your beloved voice resonates in my ears; there enters into me finally something of yourself, your noble and beautiful thoughts come to be reflected in my soul). ${ }^{217}$ Surely, behind her passionate language there are these familiar verses from the Song of Songs, Le Cantique des Cantiques:

214 "Je passé des heures à lire et relire tes bonnes lettres: elles sont ma consolation, en attendant que j'aie le bonheur de venir te retrouver. Je te dirai ce que je pense, ce que je ne cesse de t'écrire: j'ai de l'espoir, beaucoup d'espoir. J'ai la conviction que tout ira bien, que ta réhabilitation sera éclatante et que la vie te réserve encore du bonheur [. . .]"

215 Marc-Alain Ouaknin writes: "Eclatement d'un espace littéraire: le texte ne sera plus abordé dans sa linearité, mais dans sa spatialité, son volume. Ou peut-être doit-on dire que l'éclatement du texte est ce qui va permettre le passage du Texte-ligne au texte-volume" (An explosion of literary space: the text will no longer be approached in its linearity but in the spatiality of its volume. Or perhaps on ought to say that the explosion of the text is what permits the passage from linear Text to volumetext) in Le livre brûlé: Philosophie du Talmud (Paris: Leiu Commun/Sagesse, 1993), 103.

216 Ecris-moi souvent, écris moi longuement, 248.

217 Gabriel Tarde describes the fullness of conversation as a speech act and social event and consequently as a civilizing phenomenon: "Les interlocuteurs agissent les uns sur les autres, de très près, par le timbre de voix, le regard, la physionomie, les passes magnétique des gestes, et non pas selulement par le langage" (The interlocutors would act on one another, [standing] very close to each other, by the timbre of their voices, the look [they give one another], the physiognomy, the magnetic passes of their gestures, and not only by the [spoken words of their] language) L'opinion et la foule, 88. Although he mentions some of the facets of conversation lost in a telephonic version, as Proust does in greater detail (perhaps referring to this section of Tarde), the attempt of novelists (rather than dramatists and actors on the stage) to reproduce the fullness of the occasion become acute in the development of fiction in the nineteenth century when rhetoric per se is suppressed in such writing. For Lucie and Alfred, the process of inscribing their letters surpasses both the efforts of orators, playwrights, novelists and others because this couple is compelled to create in letters subject to excruciating censorship across vast distances of geographical and epistemological space and in a time-scheme that lacks order, coherence or control by themselves. Note too in Tarde's expression about magnetic passes in the gestures of the speakers in a conversation, that he thinks they hypnotize each other and themselves, forming imitative shape and boundaries to their communication. In a sense, too, Alfred and Lucie also create a magnetic relationship of this kind in their letters, and when they tell each other they read and reread these epistles in the silent, lonely days and nights, they recognize part of the phenomenon. 
C'est la voix de mon bien-aimé!

Le voici, il vient,

Sautant sur les montagnes,

Bondissant sur les collines,

Mon bien-aimé est semblable à la gazelle....

Mon bien-aimé est à moi, et je suis à lui ....

(CC $1: 8,9,16)$

These lines not only resonate through liturgies of both Jewish and Catholic worship but echo through secular courtly love songs long afterwards, brought closer to general knowledge in the nineteenth century through a host of biblical plays, music performances, and pseudo-medieval histories. The figurative language of resonance of sound and projection of light, psychic entry of one soul into another and transformation of the spirit, all this also plays its part in the metaphysical discourses that Alfred and Lucie seem to recreate for each other, almost without being aware of it, inadvertently. Another metaphor used by Lucie is that of resonating in harmony with one another, as in her letter of 9 December, 1895:

Lorsque je lis ces lignes toutes pleines de volonté et d'énergie, je sens que mon être tout entière vibre avec toi, ton activité morale entretint mes forces et il me semble qu'elles sont doubles par la puissance de ta volonté. ${ }^{218}$

When I read these lines full of will and energy, I feel that my entire being vibrates with you, your psychic activity supports and repairs my strength and it seems to me that it is doubled by the power of your will.

Although there might be echoes here of Nietzsche's and other nineteenth-century philosophers' theories of the will to power and the force of destiny, the imagery in Lucie's and Alfred's letters vibrates rather within a zone of allusions derived from kabbalistic writings and seventeenth-century erotic poetry. However, this language has much more 
than a rhetorical wit to it: it is their only way of expressing the violent passions within them. Unlike even the most subtle or naturalistic descriptions of conjugal desires in the novels of the period, the letters of Lucie and Alfred break out of all conventional bonds of propriety. More than that, Lucie's images and concepts come close to the secret heart of Kabbalah as expounded by Wolfson. ${ }^{219}$

Just before the last letter discussed above, Lucie writes on 28 November, 1895, that the letters she puts in the mail to be transported across the sea are "lignes inanimées et froides" (inanimate and cold) and it is a "déchirement" (a rending to pieces) to send them out, ${ }^{220}$ as though someone had ripped a foetus from her womb. How can he respond to the tenderness and affection of her feelings when the words once inscribed and sent into the world are like a horrible abortion? ${ }^{221}$ Each epistle is consequently like a still birth: "Le sentiment est trop violent pour que je puisse le décrire" (The passion is too strong for me to describe). ${ }^{222}$

Before he ever receives such a letter, Alfred is still writing on 27 December, 1895, that he is in anguish over the failure of mail to arrive. Yet in another sense, they have already established such a powerful bond between them through the writing of letters that each can intuit what the other would write or has written on pages that are lost in the

219 Wolfson: " . . a according to kabbalistic phallocentrism, the feminine is ontologically localized in the male organ. Thus, the engendering mythic structure of kabbalistic symbolism may be referred to as the androgynous phallus. The unification of masculine and feminine symbolically signifies the ontological reintegration of the female to the male. Representations of the Shekhina as an autonomous feminine persona are characteristic of the state of exile and fragmentation. Even the image of the Shekhina as a bride adorned for her wedding is a transition between exile and redemption. The latter is fully represented when the bride enters the nuptial chamber and is transformed therein into the crown of the bridegroom. This transformation represents the final restoration of the female to the male, for the bride becomes the corona of the penis" (Through a Speculum that Shines, 275, n. 14).

220 Ecris-moi souvent, écris moi longuement, 266.

221 André Maurois: "In a child's mind words are not well defined; they designate zones of emotion more or less extensive and not clearly bounded; in this respect many adults remain children all their lives" (Call No Man Happy, 15).

222 Wolfson cites Elijah Solomon Zalman, the Gaon of Vilna: " 'It is known that all union is dependent on sight, as it is written, '[When the \{rain\}bow is in the cloud] I will see it and remember the everlasting covenant . . . . [the sign of the] covenant that I have established' (Gen. 9:16-17) It is known that the establishment of a covenant (haqamat berit) is in [sexual] copulation." Then Wolfson says in his own voice: "The biblical idiom haqamat ha-berit is here understood as signifying the erection of the penis that is necessary for sexual intercourse, and that is dependent on the vision of the bow in the cloud: the union of the masculine in the feminine. In the phenomenal plane of kabbalistic ritual and myth, eros and vision are harnessed in an inseparable bond" (Wolfson, Through a Speculum that Shines, 286-287). 
dark and empty space between them.

Nos pensées sont communs, nos cœurs ont toujours battu à l'unisson, nos âmes vibrent aujourd'hui ensemble et veulent leur honneur avec l'ardeur brulante d'êtres honnêtes frappés dans ce qu'ils ont plus précieux. ${ }^{223}$

Our thoughts are common, our hearts are always beating in unison, our souls vibrate today together and wish for their honor with the burning ardor of truthful creatures beaten down in what they hold most precious.

Again on 31 December, 1895, as the New Year comes in, Alfred moans that he can only live with and because of Lucie; everything in himself is dependent upon her. Out of the depths of the tomb, of the excruciating silence of his cell, de profundis:

J'exhale des cris de douleur, cris de souffrance, de quelques noms qu'ils se nomment, le cour est toujours vaillant s'il ne sait pas toujours se taire. ${ }^{224}$

I breathe out cries of grief, cries of suffering, of several names which it names, my heart is always valiant if it does not always know how to keep its silence.

The plea is not towards God the Unnamed and Unnamable, but to the three names always in his heart and on his lips-Lucie, Pierre, and Jeanne. It is this most blasphemous of religions that keeps Alfred alive, much more so than his cult of reason and truth, his belief in justice and in France. ${ }^{225}$

By 26 March, 1896, the conditions under which Alfred lives on Devil's Island have become worse than ever. The more efforts are made in

223 Ecris-moi souvent, écris-moi longuement, 269-270.

224 Ecris-moi souvent, écris moi longuement, 272.

225 Eleazar of Worms: "The Creator has no body, physical stature, image of form at all .... The glory is an appearance of the resplendent light which is called Shekhina, and the will of the Creator shows and images that very light to the prophets, according to the hour, to this one as that [form] and to the other as that ... The appearance of His splendor, which is His glory, is like a consuming fire, and is called Shekhina" (cited in Wolfson, Through a Speculum that Shines, 214). 
Paris to call for a revision of the trial he had undergone two years earlier, the more the authorities in Cayenne are told to make life so uncomfortable for the single and singular prisoner on Ile du Diable that he will do something desperate. If he dies, the instructions go, his body should quickly be disposed of at sea for the sharks to take care of, rather than risk a returning a martyr's corpse to France. Yet Alfred tries to keep the information of his condition from Lucie, and the letters continue to manifest a timeless and placeless existence of separations, loneliness, hope, and encouragement. Thus, he writes with exquisite understatement and painful irony:

Je suis un peu comme le malade sur son lit de torture qui souffre le martyre, qui vit parce que son devoir l'y oblige et qui demande toujours à son médecin: "Quand finiront mes tortures?"226

I am a little like the sick man on his bed of torture who suffers martyrdom, who lives because his duty obligates him to and who always asks his doctor: "When will my tortures come to an end?"

The new regimen means that Alfred is shackled to his bed every night, his view of the sea blocked by a palisade built around his tiny hut, the fresh air cut off as well as the light, and the number of guards observing but never speaking to him round the clock increased. Letters are withheld more often, and the arrival of books and magazines is continuously delayed. Yet could Lucie read past the effort to make her think his language merely exaggerates his daily life in prison? It would only take reading past the insignificant phrase "un peu comme la malade" to grasp the reality. He has always suggested strongly that his tortures were physical as well as "morales" and that "cet infernal supplice"227 (this infernal agony) has two objective essences: the pressure on his delicate and excitable nervous system and the threat to his very physical existence. But can she believe that supplice and torture are not figurative constructs and are actual cruel and excessive punishments, acts of sadistic 
violence? The "abominable cauchemar dans lequel nous vivons" 228 (this horrible nightmare we live in) must be the literal reality in which they find themselves. The phantasmagoria does not blow away when the wind dissipates the clouds of smoke and the magic lantern is switched off.

Je viens jeter dans mes lettres les cris d'angoisse et d'impatience de mon âme, et j'en souffre ensuite tout un long mois, en pensant à l'émotion que tu vas avoir, et j'en suis plus malheureux encore,

I have thrown my cries of anguish and the impatience of my soul into my letters, and I have suffered from that for a whole month in thinking of the emotion which you will have, and I am even more unhappy.

For he knows that his missives are not neutral reports or merely rhetorical cris du coeur; they are part of himself, and part of the agony that crosses the sea and becomes part of Lucie, and when they enter into her soul they are doubled, not diminished. On those increasingly infrequent times when her letters do arrive and he can read her words, drawing their content-and the physical embodiment of her longing and suffering-into himself, it is only partly a consolation and a relief to him. He feels like a madman full of grief, and his head blows up, ready to explode and unable to understand anything, like the man with the exploding head in Georges Méliès's film: "Je suis comme fou de chagrin, ma tête gonflée ne comprend plus." 229

However, in what seems like a less stressful day, 3 September, 1896, when he can write one his longest letters to Lucie, he hints at how she should interpret his words, using directions that seem as though they were lifted directly from Maimonides's council to his pupil in The Guide of the Perplexed:

Tu pardonneras le décousu de cette lettre; je t'écris, comme je te le disais, sous le coup d'une émotion profonde, ne cherchant même pas à rassembler mes idées, m'en sentant même 
incapable, me disant avec effroi que je vais passer tout un mois n'ayant comme lecture que tes pauvres lignes, si courtes, où me parles des enfants, où je n'aurai rien enfin à lire de toi; cependant, je vais tout de même essayer de résumer. ${ }^{230}$

You must pardon the disconnected nature of this letter; I write to you, as though I were speaking to you, under the pressure of a profound emotion, not seeking to collect my ideas, feeling myself incapable, speaking to myself afraid that I am going to pass a whole month with nothing to read other than these poor lines, so short, where the children speak to me, where I will have nothing finally to read from you; however, I am going to try all the same to sum up.

It seems at first as though he were speaking only about his own difficulty in writing a coherent letter to Lucie and cautioning her not to try to make sense out of what is only an outburst of emotion. However, the more carefully we examine the words, the more it emerges that he is also talking about how all letters should be read, and using negative and fragmentary hints - as the Rambam advised-he outlines a more subtle method of analysis, a midrashic exercise. The difference between written and spoken discourse is elided. The words that come out under the pressure of intense emotional stress do not just mirror the disconnected and illogical words that flow out. They also embody the deepest, most secret passions of their soul, the tortuous conditions of both their lives having sensitized each to a degree of intuitive comprehension never before experienced in their marriage. It will indeed be necessary to collect his apparently random and scattered thought to make sense of what he-and she-are trying to say to one another. But the secret meaning is not a veiled allegorical discourse that needs to be decoded and spread out in the sunlight. Instead, it is the very supernal superverbal love and loyalty of their relationship that needs to be manifested mutually in their souls, a kind of affection and trust that lies outside all confines of bourgeois domesticity or romantic love in literary tradition. 
It is something akin to the mystical intention and cleaving of Kabbalah, yet outside the norms of those mystical exercises as well, because it is part of an attempt to rectify the world of French justice and truth. The closest analogue is the letters of the children, innocent of the intentions of their parents and transcribed for ostensible reasons other than being part of the mutually longed-for paternal sensuous embrace. When Lucie pens the letters from Pierre and Jeanne, adjusting their childish words to the written mode, she seems to disappear from the letters she writes to Alfred. Yet it is this selfless withdrawal from the handwritten pages of her epistles that mimics the tsimtsum, the contraction of the Godhead into His own mysterious and ineffable otherness (En-Sof), that leaves a created and creating space (makom) for the Shekhina to take shape, to enter into this world (ha-olam hazeh), and to dwell with Israel in exile and accompany the children of Israel on their long exodus from the lands of darkness, idolatry, and superstition-indeed, to be with and in Israel, each and every individual.

Did or could Alfred and Lucie Dreyfus know enough to be aware of what their letters are saying in the interpretations we have shown, or are our midrashings too far-fetched to be sustained by the documentary facts in the historical record? I think that Alfred goes in and out of such an awareness, as does Lucie, and only under pressure, when their epistles seem to give them each mutual reassurance strong enough to maintain the illusions they wish so intently to maintain, do they believe - and know - what they are saying. There is no explicit proof that either of them actually did read, hear lectures or sermons on, or think about rabbinical and kabbalistic ways of thought, but had they been so inclined, as we know from studies of what Marcel Proust was reading at about the same time, the information was available in French translations of classical Jewish volumes and in articles being published in reviews of the Jewish Consistory.

Furthermore, with his fluency in German and his connections in German-speaking lands, Alfred could have gone further in his readings, as well as attended lectures and seminars on his travels into Alsace and Switzerland. Nevertheless, the proof is in the pudding, and when one or the other of the couple-or both together-creates little disquisitions and poetic conceits or midrashim that conform more or less to rabbinical precedent, then our own readings require us to make explicit what is implicit in their texts. 
These impressions and illusions she wishes she could actualise are fully Jewish in their import, without, however, necessitating either Alfred or Lucie to know or say that they are. On 5 March, 1897, the wife tells her husband,

Quand je t'écris, au moins, j'ai quelques instants d'illusion, la plume, l'imagination, la tension de la volonté me transportèrent près de toi, là, tout près, comme je voudrais être, te soutenant, te consolant, te rassurant sur l'avenir, et t'apportant tout l'espoir que mon cœur contient renfermé et que je voudrais tant te communiquer. ${ }^{231}$

When I write to you, at least, I have several instants of illusion, the pen, the imagination, the tension of my will would carry me close to you, there, so close, just where I would like to be, supporting you, consoling you, reassuring you of the future, and carrying to you all the hope that is wrapped up in my heart and that I would so much want to communicate to you.

Yet the terms of this metaphysical conceit that both letter writers try to generate by force of will cannot be equated with kabbalistic ecstasy. The momentary instants of feeling that make them believe they have transcended the vast ocean between them or crossed over into a realm of experience already at peace and governed by justice and truth cannot be sustained, only hoped for-sometimes to the point of hallucination. In the supplement to the letter of 12 September, 1896, discussed earlier in this chapter, Alfred remarks,

On dit que la douleur était la grande éducatrice du cœur humain; eh bien, c'est faux, archi-faux; le malheur, autant on ne l'a pas mérité, révolte, rend mauvais, injuste. ${ }^{232}$

They say that pain was the great teacher of the human heart; oh well, that is false, hugely false, unhappiness 
rather that is unmerited, rebellion, makes one evil and unjust.

Cynically put, Dreyfus rejects the Christian idea that suffering is salutary, that it teaches the soul to be wise and forbearing, and that it prepares the believer to receive the grace of God. Not at all, he says: unhappiness arises from the experience of injustice in the world, the signs of rebellion against truth and honour, and one feels only bitterness and anger as a consequence. But once he spits this out, he tells Lucie that although he may be crushed under the weight of physical tortures and stretched to the limits of his sanity by the pressures of his rage, he, with her help, must ceaselessly labour to find the truth, to expose the perpetrators of the criminal acts against him, and to achieve their goal of a new trial and thus acquittal and rehabilitation. He reiterates, "Qu'il faut redevirir ce que nous étions, ce que nous sommes, des êtres humains, qui souffrent horriblement, atrocement, victims de la plus effroyable machination qu'on puisse rêver" 233 (We must become again what we were, what we are, human beings, who suffer horribly, atrociously, victims of the most frightful machinations one could ever dream of).

In Jewish tradition, the victim of injustice must never give in, but struggle on in heart and soul, by reason and through faith, waiting for but not dependent upon a divine sign, and the goal is to become fully and truly human, a mensch, a willing partner in the covenant of the law. Dreyfus acts and thinks and feels not on his own behalf in some private inner relationship with an absent God, but through and with the support of his wife and on behalf of their children. ${ }^{234}$ Thus this supplement

233 Ecris-moi souvent, écris moi longuement, 316.

234 A brief letter from Jeanne on 10 October 1896 permits us to see what Lucie is teaching the children in Alfred's absence, and we must assume that she would not instruct them in any beliefs contrary to his own or what they have already decided should be taught to the little ones: "Papa chéri,/ Je voudrais que tu reviennes bientôt, il faut que tu le demandes au bon Dieu, moi je lui demande tous les jours./Je t'embrasse beaucoup beaucoup./Ta petite Jeanne" (Dear Papa, I wish that you come back soon, you must ask the good God, I ask him everyday. I kiss you lots and lots. Your little Jeanne" (Ecris-moi souvent, écris moi longuement, 324). Similarly on 25 December 1896, Pierrot writes to his Dear Papa that he often writes "au bon Dieu" for the return of his father (Ecris-moi souvent, écris moi longuement, 332). Both children, it would seem, have been taught their prayers and a belief in God, as well as Bible stories; what these prayers, beliefs and stories consisted of, however, remains lost in the mists of time. Remember that Lucie transcribes the letters on behalf of the children and probably coaches them in what to say as well. She uses a Catholic expression, "le bon Dieu," a formulaic not to be found in Protestant cultures, and perhaps here, a little like Proust's mother, she felt closer to the majority French culture than the minority Christians. It 
to this epistle concludes with a statement of faith suppressed in previous editions of the letters:

Nous devrons avoir cette foi qui nous fait accepter les plus dures situations, pour arriver à rendre à nos enfants un nom sans taches, un nom respecté.

Oui chère Lucie, cette foi, il faut que tu l'aies, il faut que vous l'ayez tous; elle doit planer au-dessus de toutes les souffrances, de toutes les douleurs humaines. ${ }^{235}$

We must have this faith, so that we can accept the most difficult situations, in order to be able to render to our children a name without stains, a respected name.

Yes, dear Lucie, this faith, you must have it, all of you must have it, it must soar above all sufferings, all human pains.

This is an intellectual faith, not a vague spirituality; it is a commitment of the heart in all knowledge of its implications and consequences. This time, Alfred calls on not only Lucie to pledge herself to the duty they have before them but to all the others in their two families. The clearing of his name of all infamy includes all of them, all generations, backwards and forwards in time, for it is not an individual matter; it belongs to the family, and to all of Israel. More than that, to see that Alfred has the proper titles, rank, and honour restored to his name is also to ensure that the dignity and reputation of the God of Israel in the world is restored.

This comes close to being, but always remains just below the surface of his text, and there is no doubt also of his consciousness, an admission that the key causal factor in his horrible nightmare is anti-Semitism. Yet despite such a "long examen de conscience," as he calls it, the long dark night of suffering ("cette nuit atroce que je viens de passer") continues to pass into a day that merely precedes the next. This meditation ("réflexion") that comes from his hallucinating brain ("mon cerveau halluciné")

may seem to her a more endearing and personal term to speak of a Jewish deity who in Yiddish can be called Gottenyu, my dear little God.

235 Ecris-moi souvent, écris moi longuement, 316-317. 
continues his dreadful nightmare ("ce lugubre cauchemar"). ${ }^{236}$ But to what end these meditations, he does not know, and he cannot understand himself when Lucie is there in his dreams or in her letters to help him out. ${ }^{237}$ Only in her letters does he find a calm moment and place. Yet "je comprenais, sous le calme apparent de vos lettres, quelle douleur atroce se cachait" (I understand under the apparent calm of all your letters what an unbearable pain was hiding). ${ }^{238}$

There are moments like this when Alfred feels despondent because he does not believe the family back home appreciates fully what he is going through on Devil's Island. Because Lucie cannot report on the progress of efforts for a revision of the trial or the extent to which new evidence has been piling up of the perfidy of the officers and court officials, as well as politicians, in their collusion against him from the very beginning of the case, he doubts sufficient measures have been taken on his behalf. He also finds that Lucie's letters seem to miss out on the directions he has given her or that she has misread the feelings he has expressed. It is sometimes as though someone were to wake up in the night and find himself blind and deaf, unable to know what has happened to him, unaware that anyone is trying to help, frightened that the world has disappeared into a vast, impenetrable, and silent darkness.

Je relisais aussi, comme chaque mois, les lettres que j'ai de toi, les compagnons de ma profonde solitude, les lettres de tous, et je crois que tu n'a pas saisi entièrement ma pensée, un peu confuse forcément dans les nombreuses lettres que je t'ai écrites. ${ }^{239}$

I was also rereading, as I do every month, the letters I have had from you, the companions of my profound solitude, the letters from all of you, and I believe that you have not fully grasped my thought, inevitably a little confused in the numerous letters I have written to you.

He wants to excuse her, take some of the blame on himself for not

236 Ecris-moi souvent, écris moi longuement, 317.

237 Ecris-moi souvent, écris moi longuement, 318.

238 Ecris-moi souvent, écris moi longuement, 319.

239 Ecris-moi souvent, écris moi longuement, 329. 
writing clearly enough and for having written too much in a confused and disorderly way. He doesn't want to blame her, become angry with her, and risk alienating his own and only support throughout the whole ordeal. So when he speaks to her about avoiding rancor or bitterness against any individuals who might be behind the crimes against himthat is, to maintain a dignified and calm posture in all her dealings with the outside world, especially the persons responsible for seeing his appeals through to their justifiable conclusion, he is also speaking to himself, to quieten his frustration and his impatience-and his doubts about her loyalty and determination. 'J'ajoute qu'il ne s'agit d'apporter dans cette horrible affaire ni acrimonie, ni amertume contre les personnes. Il faut viser plus haut" (I must add that it is not a matter of bearing acrimony nor bitterness against individuals in this horrible affair. One must aim much higher). Perhaps also, ironically, when he tells her to aim higher-higher than, in the immediate import of the sentence, the underlings in the whole sorry affair, and look to God for help, support, and understanding-he might be also saying, "Watch out for the persons in the most responsible positions in the army and the government." Although it is most unlikely that Dreyfus could think such a thing at this time in the affair, because of his idealism and the limits on his knowledge of what is happening back in Paris, nevertheless this caution and hint to seek out the culprits in the highest offices in the republic will be all too true in retrospect.

On New Year's Day of 1897, Lucie begins her letter to her dearly beloved Alfred with the usual mixture of hopes and encouragements for a peaceful future through the resolution of their problems. Then, in a passage suppressed in the earliest editions of the letters, she says, "Que Dieu enfin ait pitié de nous" ${ }^{40}$ (May God have pity on us!), thus seeming to break the taboo against crying out for pity and mercy, as though the couple were Christians; but to push these common expressions, embedded in French life and culture, though indeed imbued with Christian overtones as though they could mean more than the context allows them to resonate, would be to expect far too much of Lucie and Alfred as theologians. Her plaintive letters continues: "Qu'il nous permettre de vivre le repos, qu'il mette un terme à nos angoisses, aux blessures de notre coeur et de notre âme" (May He permit us to live in repose, may He put an 
end to our anguish, to the wounds in our heart and in our soul), formulaic demands for release from intense pain in the cruel and unmerited catastrophe of their lives.

At the end of the letter, in an appended statement, Lucie returns to the more familiar language of their interprenetrative experience of one another, where they regarded one another's letters as reflections of each other's souls ("un reflet de ton âme, de ta pensée") and as a mystical space in which they converse, their usually tightened nerves relaxed ("ce qui m'a détendu les nerfs et reposée un peu"). ${ }^{241}$ In response, as it were, on 6 January, 1897, Alfred writes something quite similar, though in the language of his own more masculine sensibility, affirming that the goal is always the same-the rehabilitation of the family name:

Mais, hélas! si l'on peut être stö̈que devant la mort, il est difficile de l'être devant la douleur de chaque jour, devant cette pensée lancinante de se demander quand finira cet horrible cauchemar dans lequel nous vivons depuis si longtemps, si cela peut s'appeler vivre que de souffrir sans répit. ${ }^{242}$

But, alas! if one can be stoical before death, it is difficult to be [so] before daily pains, before this penetrating thought of asking oneself when will it ever end, this horrible nightmare in which we have lived so long, if it can be called living to suffer without respite.

The specific terms may be more classical and impersonal, but the anguish is the same, and the same cry for relief binds Alfred's letter to Lucie's. Yet Lucie has another strategy to make manifest the deepest, virtually unspeakable anguish in her heart: the projection of her feelings into the voice, person, and condition of the children. Thus, on 1 February, 1897, she tells her husband about little Jeanne's illness and how it has been passed on to Pierrot. The girl had a mild case of chickenpox and now the boy has it, both desiring to be pampered and fondled ("d'être dorloté et câliné"). ${ }^{243}$ To show this otherwise repressed longing, the wife

241 Ecris-moi souvent, écris moi longuement, 342.

242 Ecris-moi souvent, écris moi longuement, 345.

243 In a section of the letters previously unpublished: Ecris-moi souvent, écris moi longuement, 348. 
and mother signs her letter with a never-before-used phrase: "Ton affectionnée Lucie" (Your affectionate Lucie).

It is possible to see Alfred moving, by the force of his will, into selfanalysis, while at the same time, under the pressures of the physical and moral tortures he is undergoing, slipping back into black despair. In his letter of 24 April, 1897, he starts by saying that it is utterly painful to keep waiting for her letters, and because he has no letters from her to answer, his own are filled with repetitions of what he has written too often already. Repetition warms his heart, as though he were generating heat to make a spark, or as though he were in sexual congress with her, and yet for all that, the constant iteration of words and phrases does not relieve him. The agony is inexpressible, and the inexpressible does not go away through a one-sided expression, even if he were to howl like a beast. ${ }^{244}$ When he attempts to pull himself together and transform this personal pain into a statement of idealism, his love and loyalty to the nation, ${ }^{245}$ when, indeed, he sees himself a martyr to Lucie and to France, he becomes detached, as he often says, from the essential core of his self, his Jewishness:

Et la réalité, la voici, toujours la même: c'est que dans cette horrible affaire il y a un double intérêt en jeu, celui de la patrie, le nôtre, que l'un est aussi sacré que l'autre. ${ }^{246}$

In reality, the here and now, [is] always the same: it is that in this horrible affair there is a double interest in play, that of the nation, and our own, which is as sacred as the other.

The words are cryptic, cramped, ambiguous at best: the double interest at play is on the one side, clearly that of France, "our nation," his and Lucie's and their children's; he also says, "[M]a vie est à mon pays" (my life belongs to my country), but on the other, the interest is in his

244 Ecris-moi souvent, écris moi longuement, 359.

245 Romain Rolland's Olivier remarks of the Jews: "The best of them . . . make the mistake, in all sincerity, of identifying the destiny of France with their Jewish dreams ..." (Jean Christophe, vol. II, 385) and then a little later: "The Jews are well off in France: I am glad of it: but they must not think of turning France into Judea!" (II, 386).

246 Ecris-moi souvent, écris moi longuement, 360. 
honour, his integrity, and his innocence. He owes it to Lucie to stay alive and healthy and sane. He owes it to his children to fight against the machinations of the state, the army, and the judiciary to clear his name of all taints. What he owes to the family and to and through his love to Lucie is his Jewish self. In another sense, behind or inside this paradox, "le nôtre" refers to the interest he has in honouring the name of the God of Israel, insofar as Lucie has come to embody that concept of the sacred. When he speaks of name and country and patrimony, each word can reverberate with Jewish meanings, the Shem of the God who blesses all things, the Makom, the place which is infinite and eternal and which is also the Eretz Yisroel, the Promised Land of Israel, and the Zekhut, the legacy of obligations of the deity accumulated by all of Israel by the righteous of all generations and to which all of Israel is entitled to a portion in times of need and despair.

Most of the time Alfred speaks outside the explicit language of religion and tries to secularise and Frenchify his hopes and dreams, to juxtapose rather than oppose or prioritise his love of Lucie and of France. Thus, in his letter of 5 July, 1897, he tells his wife:

Je joins les mains dans une prière suprême, que j'adresse encore à tous ceux [à qui] j'ai fait appel, pour qu'ils t'apportent un concours plus ardent, plus généreux que jamais dans la découverte de la vérité. ${ }^{247}$

I join my hands in a supreme prayer which I address to all those to whom I have appealed for them to bring to you a more burning unity, more generous than ever for the discovery of the truth.

An ardent prayer, with joined hands-anything but a Jewish gesture, but a commonplace of French Catholic culture so deeply embedded in the ordinary language that the significance is totally neutralized-directed not at God but at his family and their allies, for them to double their efforts on his behalf. ${ }^{248}$ The news from home is totally inadequate

247 Ecris-moi souvent, écris moi longuement, 367.

248 On 22 July 1897, Alfred writes in the same figurative gesture of joined hands in prayer: Ecris-moi souvent, écris moi longuement, 370. 
to his emotional needs. He does not realize-how could he?-what has already been accomplished and how close the nation is to the idea of his rehabilitation. Yet he is also correct, insofar as it will not be until Emile Zola forces the issue with his public J'Accuse that the most spectacular stage of the affair is set off. As the censored passages in Lucie's letter of 15 July, 1897, show, the truth was on the march-"Cette fois je m'avancerai avec plus de certitude encore et je t'affirmerai d'une façon absolument catégorique que ton nom sera lavé de cette horrible souffrance, que la certitude de ta rehabilitation est absolue en moi" ${ }^{49}$ (This time I will be advancing with even more certitude and I can affirm to you in a fashion absolutely categorical that your name will be cleansed of this horrible suffering, that certainty of your rehabilitation is absolute in me)-yet there was no way he could know it. ${ }^{250}$ Whatever truths he could read out of her letters that did arrive were oblique, fragmentary, and understated. The point at issue here, though, is that whenever Dreyfus wants to make a statement that could be read by the public-even if that public is only himself, Lucie, and the censors who read their letters-his language is vague, pompous, and secular. When he is crushed by circumstances, crying out in pain, appealing to Lucie for moral and emotional support, he reveals the hidden core of his being, obliquely, to be sure, but profoundly true in his Jewishness.

Alfred writes what he calls "mon testament moral" on 20 August, $1897,{ }^{251}$ a letter stopped by the censors from being sent to Lucie, and existing only in fragments. Although he speaks insistently of "l'extrême franchise, la franchise brutale même" (the extreme frankness, brutal

249 Ecris-moi souvent, écris moi longuement, 369.

250 Further explicating mahloquet, Ouaknin draws on Emmanuel Lévinas' De Dieu qui vient à l'idée (Paris: Vrin, 1982, 166): "la parole de question est 'la première fissure visible dans le psychisme de la satisfaction'. Le refus de la satisfaction, du contentement où, en d'autres termes, de la totalité est un des traits essentiels de la Mahloquet. La question brise la totalité, le concept, elle est l'ouverture et chemin de (et vers) la transcendance, elle est source de Hidouch, de savoir transcendant" (The word of the question is "the first visible fissure in the psychism of satisfaction." The refusal of satisfaction, of contentment or, in other words, of the totality is one of the essential characteristics of Hidoush, of transcendant knowledge" (Le livre brûlé, 233). The purpose of the questionings and challenges of authority is to "make it new", new in the sense of a continuous, dynamic overflowing of meaning, never stuck into a fixed iconic statement or of what is true, since such a truth is false, is an idol. "L'importance du Hidouch," writes Ouaknin, "réside dans le fait qu'il introduit une discontinuité dans le rhythme de la conscience et dans le train de l'être, qu íl brise le bloc de l'être" (The importance of Hidoush resides in the fact that it introduces a discontinuity in the rhythm of consciousness and in the train of being, that it breaks the [solid] block of being") in Le livre brûlé, 243).

251 Ecris-moi souvent, écris moi longuement, 375. 
frankness even), it is difficult to see in what survives of this letter what goaded the prison authorities into stopping the epistle from going to its destined reader. In contradiction to this assertion, he tells Lucie on 2 October, 1897,

Comme je te l'ai dit, mes longues lettres sont trop l'expression intime et profonde aussi bien de mes sentiments que de mon immuable volonté, pour qu'il soit utile d'y revenir; elles sont comme mon testament moral. ${ }^{252}$

As I have told you, my long letters are too much the intimate and profound expression of my sentiments as of my immutable will, so that it would be useful to return to them, they are like my moral testament.

In other words, this time around, what he calls his moral testament is not brutally frank, but carefully considered, an edited version of his hopes and aspirations. But a testament of this sort, common to Jewish tradition as a means for fathers to set out the principles by which they hope their children will live after their demise, sometimes appended to and sometimes substituted for an actual disposition of worldly goods, would normally be written in Hebrew, weaving together in melitza format many scriptural and Talmudic phrases and concepts, and would become a family treasure in itself. ${ }^{253}$ For Alfred Dreyfus, however, aside from citing Shakespeare-he speaks of Banco's (i.e., Banquo's) ${ }^{254}$ ghost from Macbeth-the legacy to his children will be the good name he hopes to be restored and the example of his own endurance under terrible duress during the whole of the ordeal of imprisonment.

This citation from Shakespeare or any other literary source, including the historians and philosophers he so extensively comments on in the cahiers, is rare, the language of Alfred remaining close to the neutral,

252 Ecris-moi souvent, écris moi longuement, 382.

253 One thinks here of the famous inscription Sigmund Freud's father wrote on the flyleaf of the Bible in modern edition and translation he had read to his son from when he was a boy and now passes on with hope that the grown man, already successful as a neurologist, would return to the Law for inspiration and guidance.

254 Ecris-moi souvent, écris moi longuement, 383. See also Duclert's lengthy note on this error and Dreyfus' love for Shakespeare, 492, n. 56. We will discuss these matters more closely when we consider the prison cahiers from Devil's Island in the second volume of this series. 
secular ideals of mid-nineteenth-century French patriotism, or, as we have been trying to show, occasionally slipping into the rhythms, tones, rhetorical tropes, and words of biblical prophecy and poetry, Jewish liturgy, Talmudic debate and sometimes kabbalistic fantasy, this slippage brought on by the extremes of torment, physical and moral, he lived through for five years of his life. Although at times Lucie picks up his lead, echoes his rhythms and words, and occasionally takes the directing role in moving through this exalted discourse, she is usually anchored to domestic matters and care of the children. She is also forced to suppress her wish to enlighten her husband as to the state of play in the project to rehabilitate him, with a few exceptions, at which time, of course, her letters are censored or stopped altogether.

In this last phase of their epistolary communications, whether intentionally or not, she begins to mimic the ringing polemics of Zola and other Dreyfusards. This can be seen in the previously unpublished letter of 20 January, 1898, as pointed out by Duclert. ${ }^{255}$ It is unlikely that Alfred was able to recognize these clues as to the advanced state of the affair, which was reaching its climax in Paris. But the closer the end comes to his sufferings, the less can he see the clues in the erratic behaviour of his jailers. Sometimes they relax their guard a little, then they increase it cruelly and sadistically. Lucie's letters, as we can now see, begin to drop their guard and speak enthusiastically about the coming resolution, but since these are the very letters held back from him, Alfred begins to doubt her commitment and assumes the worst in his legal and political position. Sensing a crisis rising again in his mental state, Lucie begs him on 6 March, 1898, to give her a detailed account of his health: "Dis-moi longuement comment tu es, comment tu te portes. Dis-le moi en toute franchise"256 (Tell me at length what is the matter with you. Speak to me in all frankness). Later still, on 7 April, 1898, she tries to explain away a misunderstanding on his part, that she is not annoyed by his repeated descriptions of his poor mental health, that she understands his position exactly and admires his courage and fortitude, and that she herself is glad to suffer along with him, to share his burdens. ${ }^{257}$ She is

255 Ecris-moi souvent, écris moi longuement, 408-409; see also 494, n. 7. She is insistent that the great burden is finally being lifted in her letter of 17 March 1898: Ecris-moi souvent, écris moi longuement, 415.

256 Ecris-moi souvent, écris moi longuement, 413.

257 Ecris-moi souvent, écris moi longuement, 417. 
even more insistent on 16 August, 1898, when she writes, "Je désire si ardemment te pénétrer de ma pleine confiance en un bon avenir prochain que j'ai peut-être manqué de clarté dans l'expression de ce sentiment. Dorénavant je tâcherai d'être plus nette" 258 (I desire so ardently to penetrate you with my full confidence in a favourable outcome soon that perhaps I missed being clear in my expression of this sentiment. From now on I will attempt to be plain).

Although Lucie can see everything coming right at last, still the weeks drag by, the months pass without an official decision, and no news she can send to him which will be confirmed by documents and newspapers. What encouraging words she does write, as on 14 July, 1898, Bastille Day, ironically are prevented from coming to him because the political factions against him, and the prison authorities, absolutely convinced of his guilt and of a Jewish plot against France, resist to the very last moment.

In late July of that last year of his imprisonment and exile, his letters change markedly. They suddenly take on the character of little essays on topics such as the education of the children or on the nature of language, as though the boundary between the epistles and the cahiers was breached. Nevertheless, just as about at the same time, in his last workbooks, the facade of intellectual objectivity and distance from his own sufferings begins to break down, here too he lets cries of pain and frustration seep into these little disquisitions:

Et si je n'écoutais que mon cour, je t'écrirais plus souvent, car il me semble ainsi-pure illusion, je le sais, mais qui soulage néanmoins-qu'au même instant, à la même minute, tu me sentiras à travers la distance que nous sépare battre un cour qui ne vit que pour toi, pour nos enfants, un cour qui t'aime. . . 259

And if I had only listened to my own heart, I would have written more often, for it seems to me thus-a pure illusion, I know, but which nevertheless comforts methat at the same moment, in the same minute, across 
the distance which separates us you feel a heart beating that only lives for you, for our children, a heart that loves you ...

Again, the more hopeless things seem, the more he expresses himself in these metaphysical terms, creating the conceit of the two hearts beating in unison or one heart in two distant places. He need not write because they are closer together than geography or the physical delivery of pieces of paper with words inscribed on them. But never have they been caught up so much in a crisis of communication, when, right on the cusp of success, their physical letters fail to arrive or are misread because of the lack of coherence, and because, at least on Lucie's side, with the confidence she has in the expected resolution to all their problems, she falls away from that sense of shared crisis that made the metaphysical union possible.

By 26 September, 1898, she writes a totally new kind of letter to Alfred, one filled with a catalogue of actions taken on his behalf: "Je veux te raconter très brièvement la succession des faits." ${ }^{260}$ Such a letter, however, she should have known, would be held back, and when it did arrive without a proper historical context and not backed up by confirming documents, it would be misunderstood by her husband. Matters reach such a point of confusion that in her letter of 22 November, 1898, she signs herself "L. Dreyfus," ${ }^{261}$ the driest, most impersonal way possible. Salutation and inner greetings are less formal, so why this strange signing off? Could it be that, so hopeful is she of an immediate release from his prison, she expects the letter to be stopped before it reaches Alfred and either held by the officials or posted back to her?

Unfortunately, nothing happens for many more weeks and months, and their letters slip back into the old routine, perhaps tinged with an even greater despair and frustration than before. In the letter of 6 March, 1898, ${ }^{262}$ again filled with demands for him to send all the details possible of his health and mental condition, as well as her apologies for the tediousness of her repeated words and phrases from previous letters over all these years, she diagnoses her moral condition as "cette obsession," manifest in the fixation on rehabilitating his honour.

260 Ecris-moi souvent, écris moi longuement, 433.

261 Ecris-moi souvent, écris moi longuement, 439.

262 Ecris-moi souvent, écris moi longuement, 412-413. 
Just as she intuits the need to make him talk through his pains and humiliations in order to draw him up out of his black hole of despair, so too she makes her treatment consist of self-abasing comments about her own lack of skill in writing and her weak intellect. Her attempts to reassure him of the light that is already breaking forth into the darkness of the mysterious case against him, Alfred does not comprehend in a way that makes her confident of his mental condition: she knows, in a way, that her letters may not be getting through; she confesses to her inadequacy in expressing herself clearly and cogently, and she fears that her husband may be too far gone in his illness to recover even after a judicial revision and rehabilitation. For example, in her letter of 7 April, 1898, she writes that they should be habituated to suffering "'irrégularité des couriers," 263 but everything is much worse than that. In a previously unpublished part of this letter,

Je me souviens quelquefois de tristesse combine je me sentais isolée, malheureuse quand je me devais de me séparer de toi pendant quelques jours, j'aurais donné beaucoup pour que ces moments envisagés avec tant d'anxiété, soient passes. Qu'aurais-je dit si j'avais pu prévoir une chose pareille, que toi mon mari bien-aimé tu me serais arraché pendant près de quatre ans, et que pendant ces quatre années, j'aurais le supplice de vivre, s'assister à la torture et d'être impuissante à la soulager, à adoucir tes souffrances. ${ }^{264}$

I sometimes recall with sadness how I felt isolated, unhappy, when I had to be separated from you for four days [during military manoeuvres]. I would have given anything for those moments I dream of in anxiety to be over. What could I have said if I had been able to foresee such a thing as you, my beloved husband, wrenched away from me for close to four years, during which I found life an agony, of being with you in your torture and being powerless to comfort you, to soften your sufferings.

263 Ecris-moi souvent, écris moi longuement, 416.

264 Ecris-moi souvent, écris moi longuement, 417. 
She had been prepared to take the normal difficulties of being a soldier's wife, of having him away from home for days at a time on official duties, but she could never have imagined this horrible fate of not only enduring more than four years of separation but of knowing intimately his terrible pains in exile, in isolation, and in torture, and of not being able to offer the right kind of relief through her letters. More than a distant witness of his misery and agony, she tells him she has been sharing every moment of his torment. Is this merely a figurative statement? She has to convince Alfred now that she has not resigned herself to his fate, accepting it all as a given, beyond remedy, as she thinks he is now accusing her of doing, but to show him that she is painfully aware of the terrible burden of responsibilities destiny has put on her to accomplish things beyond the capacity of a woman, beyond the conventional restraints put on a middle-class wife by a sexist society, and beyond the range of public sympathy a Jewish wife and mother could elicit from an essentially anti-Semitic culture. And yet this confession of inadequacies is not all true; she has accomplished much, transformed herself into something Alfred dreamed she could be-and was already, in his conceit of the Shekhina - and something, if he did know, as he will come to know, he will hesitate in speaking of because he is not all that different from other men in France at that time.

As we shall see, when we consider the carnets and journals, Alfred barely mentions Lucie and what she did for him, just as he shades from public view all his own intellectual accomplishments and interests. Partly this relapse into patriarchal and cultural conventionality is a consequence of the broken body and soul he brings back from Devil's Island and partly a result of social pressures, probably as true in his Jewish families as it is in the wider community. Nevertheless, nothing should obscure what the two writers created during the five years of the ordeal and across "perilous seas forlorn" nor, as we will argue in detail soon, the outstanding intellectual creation in the fifteen remaining prison workbooks. 